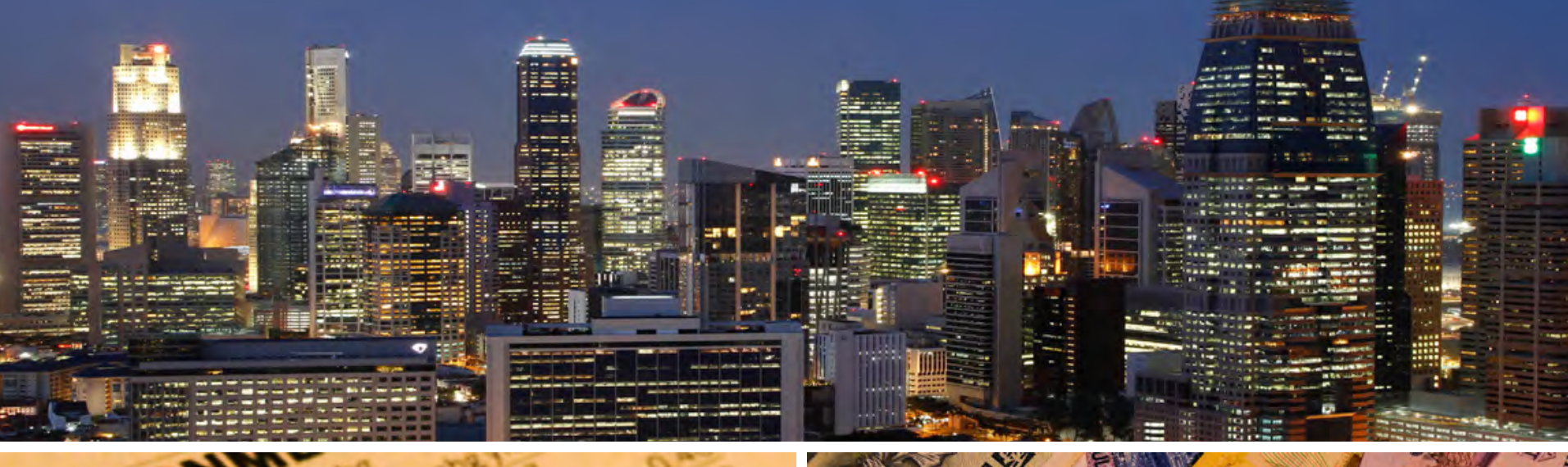

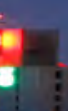

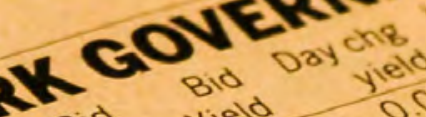

Bid vield y 0.04

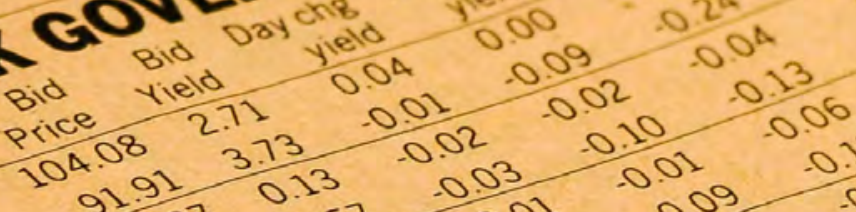
$\begin{array}{lllll}91.9387 & 0.13 & 0.03 & 0.01 & 0.27 \\ 103.53 & 1.57 & -0.01 & .0 .09 & -0.01\end{array}$

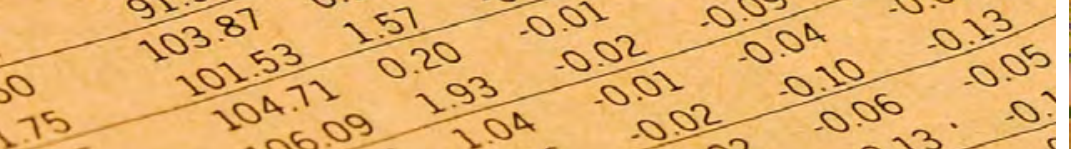

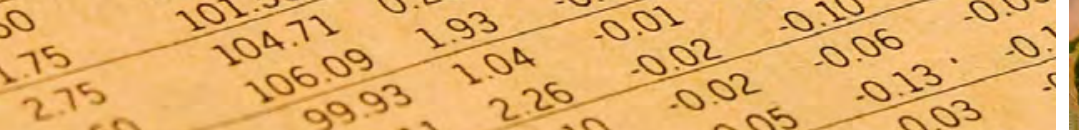

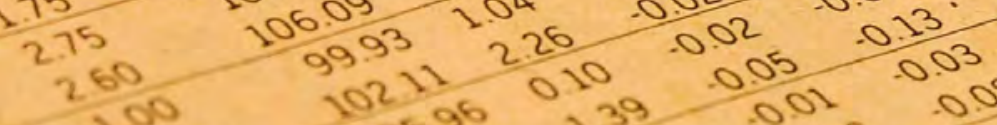

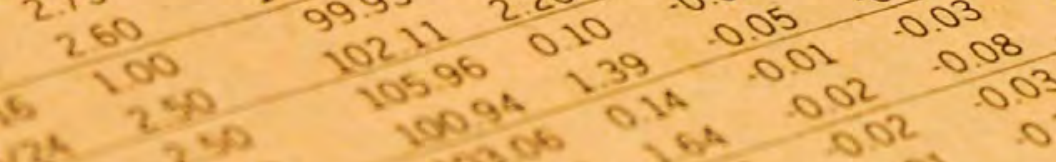
$\sin$

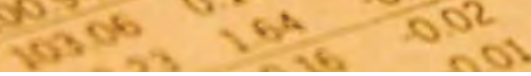

\section{ASIA BOND MONITOR MARCH 2017}


The Asia Bond Monitor (ABM) is part of the Asian Bond Markets Initiative (ABMI), an ASEAN+3 initiative supported by the Asian Development Bank. This report is part of the implementation of a technical assistance project funded by the Investment Climate Facilitation Fund of the Government of Japan under the Regional Cooperation and Integration Financing Partnership Facility.

This edition of the ABM was prepared by a team from the Economic Research and Regional Cooperation Department headed by Yasuyuki Sawada and supervised by Macroeconomics Research Division Director Joseph Zveglich Jr. The production of the $A B M$ was led by Donghyun Park supported by Shu Tian and the AsianBondsOnline (ABO) team. ABO team members include Jun Ray Bautista, Michael Angelo Cokee, Angelica Andrea Cruz, Russ Jason Lo, Carlo Monteverde, and Roselyn Regalado. Gemma Esther Estrada provided operational support, Kevin Donahue provided editorial assistance, and Principe Nicdao did the typesetting and layout.
How to reach us:

Asian Development Bank

Economic Research and Regional Cooperation Department

6 ADB Avenue, Mandaluyong City

1550 Metro Manila, Philippines

Tel +6326326688

Fax +6326362183

E-mail: asianbonds_feedback@adb.org

Download the ABM at

http://asianbondsonline.adb.org/documents/ abm_mar_2017.pdf

The Asia Bond Monitor-March 2017 was prepared by ADB's Economic Research and Regional Cooperation Department and does not necessarily reflect the views of ADB's Board of Governors or the countries they represent. 
ASIA BOND MONITOR MARCH 2017 
Creative Commons Attribution 3.0 IGO license (CC BY 3.0 IGO)

\author{
(c) 2017 Asian Development Bank \\ 6 ADB Avenue, Mandaluyong City, 1550 Metro Manila, Philippines \\ Tel +632632 4444; Fax +6326362444 \\ www.adb.org \\ Some rights reserved. Published in 2017. \\ Printed in the Philippines.
}

ISBN 978-92-9257-777-3 (Print), 978-92-9257-778-0 (e-ISBN)

ISSN 2219-1518 (Print), 2219-1526 (e-ISSN)

Publication Stock No. TCS178700-2

DOI: http://dx.doi.org/10.22617/TCS178700-2

Cataloging-In-Publication Data

Asian Development Bank.

Asia bond monitor-March 2017.

Mandaluyong City, Philippines: Asian Development Bank, 2017.
1. Regionalism.
2. Subregional cooperation.
3. Economic development.
4. Asia.

I. Asian Development Bank.

The views expressed in this publication are those of the authors and do not necessarily reflect the views and policies of the Asian Development Bank (ADB) or its Board of Governors or the governments they represent.

ADB does not guarantee the accuracy of the data included in this publication and accepts no responsibility for any consequence of their use. The mention of specific companies or products of manufacturers does not imply that they are endorsed or recommended by ADB in preference to others of a similar nature that are not mentioned.

By making any designation of or reference to a particular territory or geographic area, or by using the term "country" in this document, $A D B$ does not intend to make any judgments as to the legal or other status of any territory or area.

This work is available under the Creative Commons Attribution 3.0 IGO license (CC BY 3.0 IGO)

https://creativecommons.org/licenses/by/3.0/igo/. By using the content of this publication, you agree to be bound by the terms of this license.

This CC license does not apply to non-ADB copyright materials in this publication. If the material is attributed to another source, please contact the copyright owner or publisher of that source for permission to reproduce it. $A D B$ cannot be held liable for any claims that arise as a result of your use of the material.

Attribution-You should always acknowledge ADB as the source using the following format:

[Author]. [Year of publication]. [Title of the work in italics]. [City of publication]: [Publisher]. @ ADB. [URL or DOI] [license].

Translations-Any translations you create should carry the following disclaimer:

Originally published by ADB in English under the title [title in italics]. (C) ADB. [URL or DOI] [license]. The quality of the translation and its coherence with the original text is the sole responsibility of the translator. The English original of this work is the only official version.

Adaptations-Any adaptations you create should carry the following disclaimer:

This is an adaptation of an original work titled [title in italics]. (c) ADB. [URL or DOI][license]. The views expressed here are those of the authors and do not necessarily reflect the views and policies of ADB or its Board of Governors or the governments they represent. ADB does not endorse this work or guarantee the accuracy of the data included in this publication and accepts no responsibility for any consequence of their use.

Please contact pubsmarketing@adb.org if you have questions or comments with respect to content, or if you wish to obtain copyright permission for your intended use that does not fall within these terms, or for permission to use the ADB logo.

Notes:

ADB recognizes "China" as the People's Republic of China; "Hong Kong" and "Hongkong" as Hong Kong, China;

"Korea" as the Republic of Korea; "Vietnam" as Viet Nam; and "Hanoi" as Ha Noi.

Photo credits: Cover photos from ADB photo library and Angelica Andrea Cruz.

Corrigenda to ADB publications may be found at: http://www.adb.org/publications/corrigenda 


\section{Contents}

\section{Emerging East Asian Local Currency Bond Markets: A Regional Update}

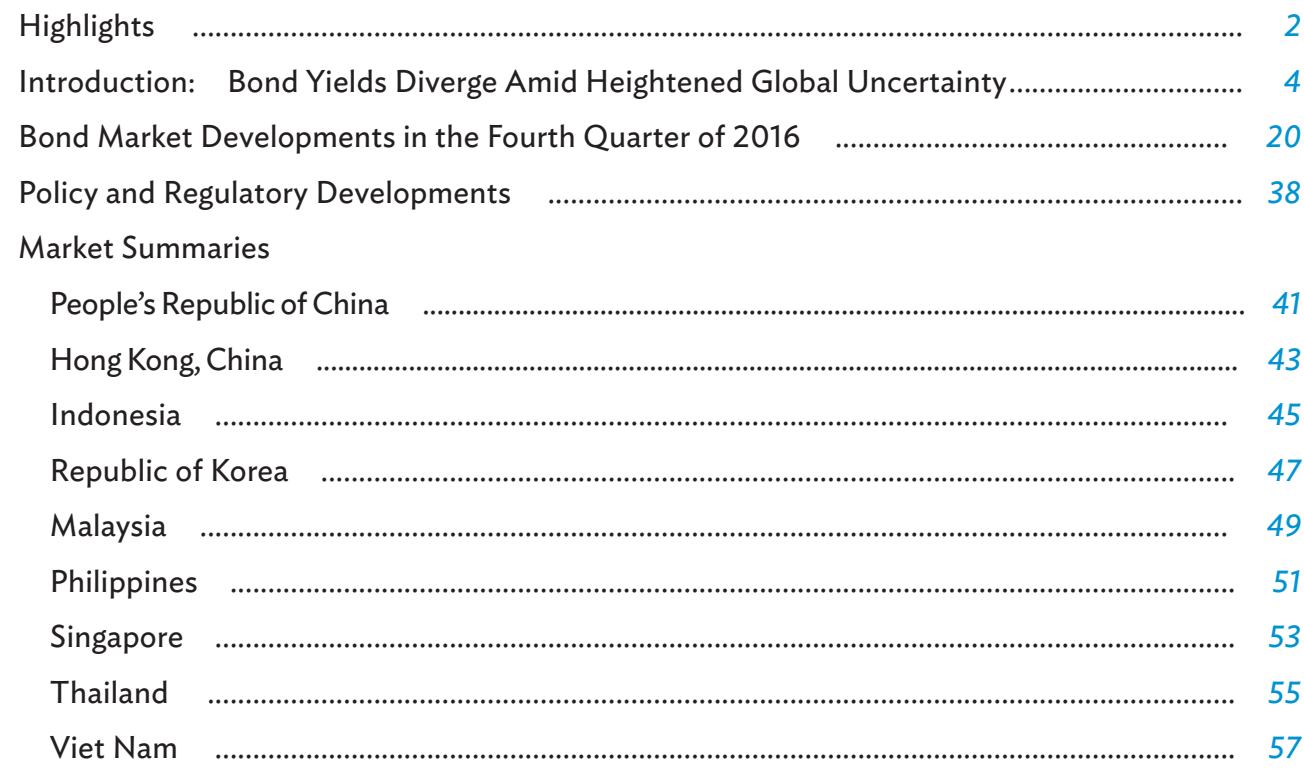





\section{Emerging East Asian Local Currency Bond Markets: A Regional Update}




\section{Highlights}

\section{Bond Market Outlook}

Local currency (LCY) government bond yields in advanced economies and emerging East Asia diverged between 31 December and 15 February. ${ }^{1} 2$ Yields in advanced economies rose while yields fell in most emerging East Asian bond markets due to heterogeneous economic fundamentals and changes in risk appetite.

In the United States (US), the Federal Reserve hinted that it would accelerate the pace of policy rate increases in 2017 on the back of a strengthening US economy as evidenced by steadily rising inflation and an unemployment rate that remains low. In the eurozone, gross domestic product (GDP) growth is stable and labor market conditions have improved. However, the European Central Bank indicated that monetary policy may need to remain accommodative. While the Bank of Japan raised its domestic growth outlook in January, it is also likely to maintain an easy monetary policy stance.

Emerging East Asia has shown signs of improving economic growth and rising inflation and a decline in LCY government bond yields was seen in most markets given improving investor confidence. The improved outlook could also strengthen emerging East Asia's financial markets against the possible reversal of capital flows in response to the Federal Reserve's expected monetary policy normalization.

The notable exception to the regional trend of declining yields was the People's Republic of China, where 2-year and 10-year yields rose between 31 December and 15 February as the People's Bank of China engaged in tightening measures to protect against asset and credit risks. Indonesia saw the biggest decline in yields in emerging East Asia during the review period, due to improving investor sentiment buoyed by a narrowing current account deficit in the fourth quarter (Q4) of 2016, an upgrade in sovereign rating outlooks from Fitch Ratings and Moody's Investors Service, rising international reserves, and various policy reforms initiated by the government.
Improving investor confidence also resulted in a decline in credit default swap spreads in all emerging East Asian economies except the Republic of Korea. Furthermore, all currencies in the region appreciated versus the US dollar except for the Hong Kong dollar and Philippine peso.

As the global economy starts to pick up, uncertainties remain that could pose threats to the region's bond markets. These include (i) the acceleration of rate hikes by the Federal Reserve; (ii) uncertainty over policies in major developed economies, particularly the US and the eurozone; and (iii) the depreciation of the Chinese yuan, which challenges growth prospects in Asia.

This issue of the Asia Bond Monitor includes three special discussion boxes. Box 1 discusses the risk of Federal Reserve rate hikes to emerging Asia's financial stability. ${ }^{3}$ Box 2 analyzes the risks to emerging Asia's financial markets stemming from policy and political uncertainties in the US and the eurozone. Box 3 tackles the impacts of the depreciation of the Chinese yuan.

\section{Local Currency Bond Market Growth in Emerging East Asia}

Emerging East Asia's LCY bond market reached a size of USD10,177 billion at the end of December, with growth moderating on both a quarter-on-quarter (q-o-q) and year-on-year ( $y$-o-y) basis.

Leading the region in terms of LCY bond market size at the end of December was the People's Republic of China, whose outstanding bonds of USD7,129 billion accounted for $70.0 \%$ of the region's total. The next largest LCY bond market in the region in Q4 2016 was the Republic of Korea's, with outstanding bonds of USD1,714 billion and a regional share of $16.8 \%$ at the end of December.

Emerging East Asia's LCY bond market continued to be dominated by government bonds, which totaled USD6,572 billion and accounted for $64.6 \%$ of the regional total at the end of December. LCY corporate bonds outstanding stood at USD3,605 billion.

Emerging East Asia comprises the People's Republic of China; Hong Kong, China; Indonesia; the Republic of Korea; Malaysia; the Philippines; Singapore; Thailand; and Viet Nam

2 Bond yields in many emerging East Asian markets have rebounded slightly since the end of the review period (mid-February), largely due to the United States Federal Reserve's policy rate hike on 15 March. Nevertheless, regional bond yields were still mostly down year-to-date as of 15 March.

${ }^{3}$ Emerging Asia comprises the People's Republic of China; Hong Kong, China; India; Indonesia; Republic of Korea; Malaysia; Philippines; Singapore; Taipei,China; Thailand; and Viet Nam. 
As a share of emerging East Asia's GDP, LCY bonds outstanding were the equivalent of $68.5 \%$ of the region's GDP at the end of December, declining from $69.2 \%$ in the previous quarter due to weaker growth in the corporate bond market. The Republic of Korea maintained its position in Q4 2016 as the market with the largest LCY bonds-to-GDP share of $117.3 \%$.

LCY bond issuance declined in Q4 2016 compared with the third quarter as most central banks and governments pared their issuance. On the other hand, corporates were more active issuers during the fourth quarter as they locked in lower borrowing costs ahead of anticipated interest rate increases in the US.

\section{Structural Developments in Local Currency Bond Markets}

At the end of December, the foreign holdings share in most emerging East Asian markets declined due to a stronger US dollar and expectations of accelerated US interest rate hikes in 2017. The share of foreign holdings in emerging bond markets fell in Indonesia, Malaysia, and Thailand at the end of December.

However, neither Indonesia nor Malaysia experienced yield upticks as a result of a foreign sell-off. These markets have become more resilient to capital outflows due to solid economic fundamentals, increased demand from domestic market participants, improved investor profiles, and better-developed local currency bond markets following the implementation of the Asian Bond Markets Initiative.

Due to risk aversion among foreign investors, foreign capital outflows were registered in Q4 2016 in all four bond markets for which data are available, with the largest net bond outflows observed in the Republic of Korea. For full-year 2016, the Republic of Korea was the only market that posted net foreign bond outflows, while Thailand recorded the largest foreign capital inflows.

Recent data from January suggest improving sentiments toward emerging market assets, with most markets experiencing a net inflow of foreign capital into their bond markets during the month. Malaysia, however, continued to experience bond outflows in January, albeit at a much slower pace than in Q4 2016.

\section{Local Currency Bond Yields}

Emerging East Asian bond yields fell for most tenors in nearly all markets between 31 December and 15 February due to improving investor sentiments resulting from strengthened economic conditions across the region.

Given emerging East Asia's improved economic prospects, the 2-year versus 10 -year yield spread rose in all of the region's markets except Singapore between 31 December and 15 February. 


\section{Introduction: Bond Yields Diverge Amid Heightened Global Uncertainty}

Yields on global local currency government bonds varied widely between 30 December and 15 February. While yields in advanced economies largely rose during the review period, yields in most emerging East Asian economies trended downward (Figure A1) ${ }^{4,5}$ Despite recent economic data pointing to a pickup in the global economy, the divergence in government bond yields reflects heterogeneous economic fundamentals and changes in risk appetite around the world.

In the United States (US), the Federal Reserve has conveyed that it is likely to accelerate the pace of its rate hikes in 2017 if the economy continues to strengthen. Recent data from the US suggest steadily advancing inflation and an unemployment rate that remains low. The Consumer Price Index (CPI) for full-year 2016 rose $1.6 \%$ year-on-year ( $y-0-y)$, and further climbed $2.5 \% y-0-y$ in January 2017 and 2.7\% y-o-y in February 2017. While core inflation is approaching the Federal Reserve's target, the labor market is also exhibiting strong momentum. Job gains averaged 190,000 per month in the second half of 2016, rising to 235,000 in February 2017. The unemployment rate stood at $4.7 \%$ in February, which is within the estimated range of the economy's long-run natural unemployment rate. In a report to Congress in February, Federal Reserve Chair Janet Yellen indicated that the US economy's performance has moved closer to central bank targets. She stated that if the labor market and inflation continue their current trends, the Federal Reserve is likely to further increase the policy rate. In short, monetary policy is gradually being normalized in the US.

In the eurozone, gross domestic product (GDP) growth remained stable and labor market conditions improved.

Figure A1: Changes in Government Bond Yields in Select Markets between 30 December 2016 and 15 February 2017

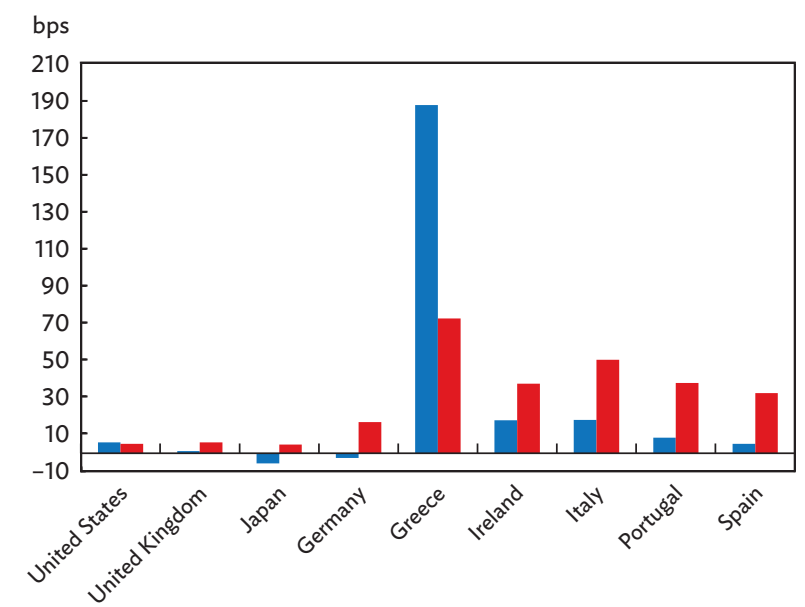

2-Year bond yields

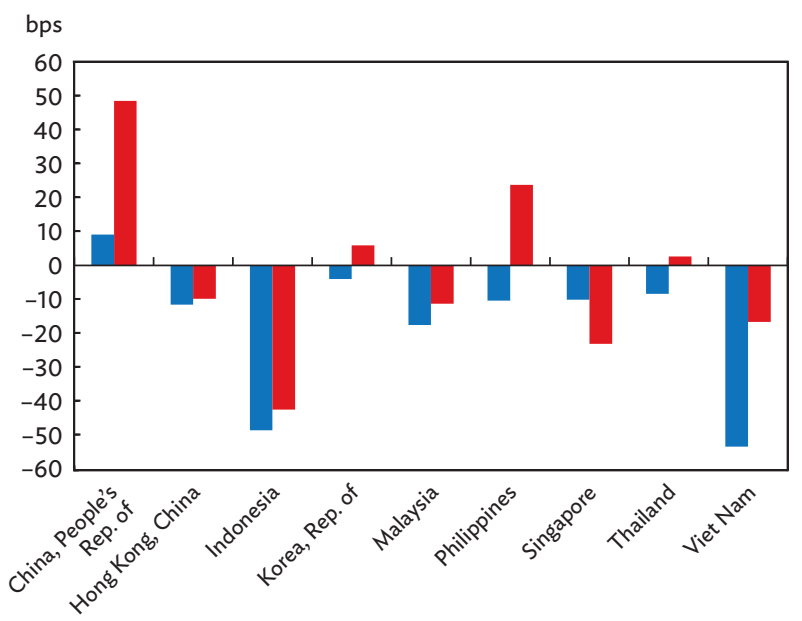

10-Year bond yields

bps = basis points.

Sources: Bloomberg LP and AsianBondsOnline.

\footnotetext{
${ }^{4}$ Emerging East Asia comprises the People's Republic of China; Hong Kong, China; Indonesia; the Republic of Korea; Malaysia; the Philippines; Singapore; Thailand; and Viet Nam.

${ }^{5}$ Bond yields in many emerging East Asian markets have rebounded slightly since the end of the review period (mid-February), largely due to the United States Federal Reserve's policy rate hike on 15 March. Nevertheless, regional bond yields were still mostly down year-to-date as of 15 March.
} 
The seasonally adjusted quarter-on-quarter growth rate was unchanged at $0.4 \%$ in the fourth quarter (Q4) of 2016 . The unemployment rate remained at $9.6 \%$ in January, the lowest reading since May 2009. Inflation rose to 2.0\% y-o-y in February 2017 from 1.8\% y-o-y in January 2017. Excluding rising energy prices, the eurozone's $y$-o-y inflation rate was $1.1 \%$ and $1.2 \%$ in January 2017 and February 2017, respectively, indicating limited underlying inflationary pressures. Given policy uncertainty associated with forthcoming elections in some major European economies later this year, the European Central Bank's President Mario Draghi hinted that monetary policy is likely to remain accommodative to meet inflation targets.

The Bank of Japan (BOJ) recently raised its growth outlook for the domestic economy. Per BOJ, the Japanese economy will grow above its potential in fiscal year 2018. The inflation forecast remained unchanged and inflation is expected to hit the central bank's 2.0\% target over the medium-term. Japan's quarter-onquarter GDP growth was unchanged at 0.3\% in Q4 2016. GDP growth in fiscal year 2017 is expected to be higher than in fiscal year 2016. ${ }^{6}$ Exports also turned positive in December 2016 and January 2017, reflecting the global economic recovery. To further buoy growth and foster inflation, the BOJ maintained its accommodative monetary policy.
Overall, promising signs of economic recovery in major advanced economies have pushed up long-term government bond yields since Q4 2016 (Figures A2, A3).

Emerging East Asia also saw signs of rising inflation and improving growth, fostering investor confidence. As a result, emerging East Asia may now be more resilient to potential capital outflows in response to the Federal Reserve's monetary policy normalization. Between 30 December and 15 February, yields on 2-year and 10-year local currency bonds fell in most emerging East Asian markets (Table A). One notable exception was the People's Republic of China (PRC), where yields on 2-year and 10-year bonds increased 9 bps and 48 bps, respectively. A rise in the PRC's yields was partly driven by a tightening monetary stance, reflecting the People's Bank of China's growing concerns with credit and asset price risks. To promote deleveraging, the central bank recently raised rates on its repurchase agreements by 10 bps and on its Standing Lending Facility by 35 bps. The other economies that saw an uptick in 10 -year bond yields were Thailand (3 bps), the Republic of Korea (6 bps), and the Philippines (23 bps).

The largest decline in yields occurred in Indonesia, where yields slid 48 bps for the 2-year bond and 42 bps for the 10-year bond, mainly due to improving market sentiments and rising risk appetite as a result of a narrowing current

\section{Figure A2: 10-Year Government Bond Yields}

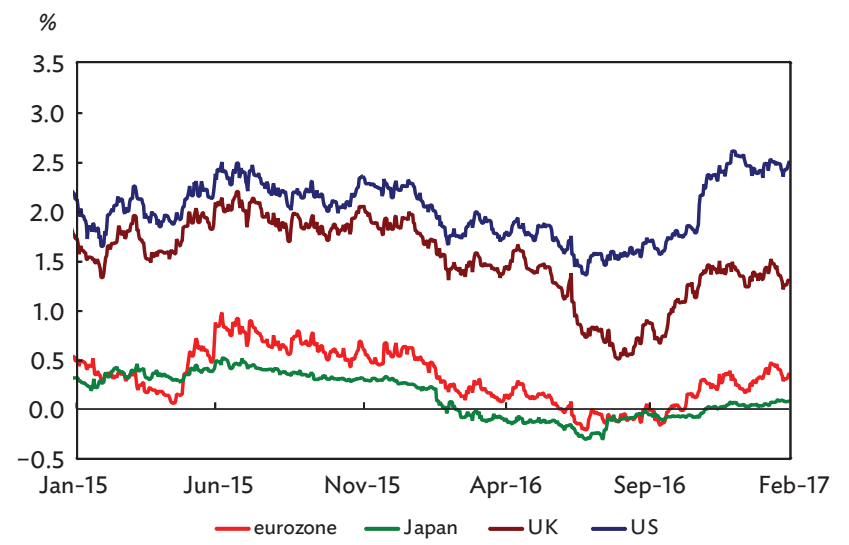

UK = United Kingdom, US = United States Source: Bloomberg LP.

\section{Figure A3: 10-Year Government Bond Yields}

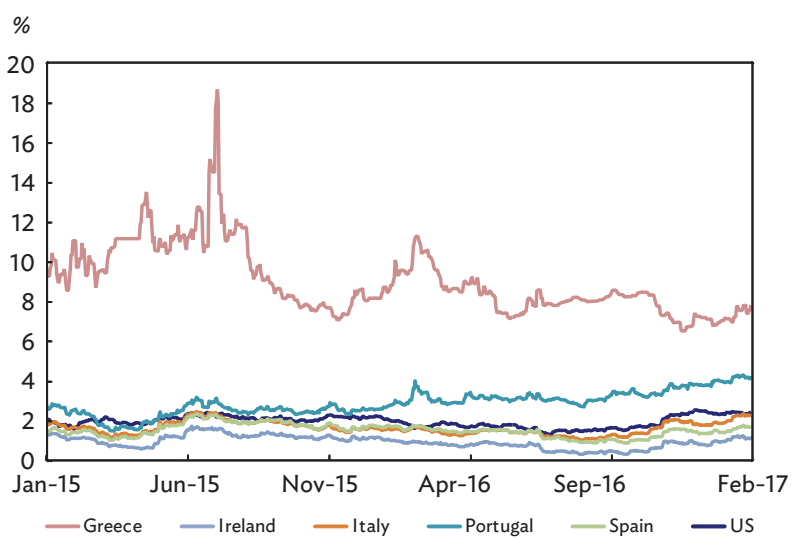

\footnotetext{
${ }^{6}$ Per BOJ's January 2017 Outlook Report, Japan's Real GDP growth in 2016 and 2017 will be $1.4 \%$ and 1.5\%, respectively, higher than the 1.0\% and 1.3\% forecasts made in October 2016 . For details, see https://www.boj.or.jp/en/mopo/outlook/gor1701b.pdf
} 
Table A: Changes in Global Financial Conditions

\begin{tabular}{|c|c|c|c|c|c|}
\hline & $\begin{array}{c}\text { 2-Year } \\
\text { Government Bond } \\
\text { (bps) }\end{array}$ & $\begin{array}{c}\text { 10-Year } \\
\text { Government Bond } \\
\text { (bps) }\end{array}$ & $\begin{array}{l}\text { 5-Year Credit } \\
\text { Default Swap } \\
\text { Spread (bps) }\end{array}$ & $\begin{array}{l}\text { Equity Index } \\
(\%)\end{array}$ & $\begin{array}{c}\text { FX Rate } \\
(\%)\end{array}$ \\
\hline \multicolumn{6}{|c|}{ Major Advanced Economies } \\
\hline United States & 6 & 5 & - & 4.9 & - \\
\hline United Kingdom & 1 & 6 & (1) & 2.2 & 1.0 \\
\hline Japan & (6) & 5 & (4) & 2.0 & 2.5 \\
\hline Germany & (3) & 17 & 1 & 2.7 & 0.8 \\
\hline \multicolumn{6}{|l|}{ Emerging East Asia } \\
\hline China, People's Rep. of & 9 & 48 & (20) & 3.5 & 1.1 \\
\hline Hong Kong, China & $(12)$ & (10) & - & 9.1 & $(0.05)$ \\
\hline Indonesia & (48) & $(42)$ & (20) & 1.6 & 1.2 \\
\hline Korea, Rep. of & (4) & 6 & 2 & 2.8 & 5.6 \\
\hline Malaysia & (17) & (11) & (21) & 4.1 & 0.8 \\
\hline Philippines & (10) & 23 & (23) & 4.9 & $(0.6)$ \\
\hline Singapore & (10) & (23) & - & 7.2 & 2.0 \\
\hline Thailand & (8) & 3 & (14) & 2.0 & 2.3 \\
\hline Viet Nam & (53) & (17) & (23) & 7.0 & 0.03 \\
\hline \multicolumn{6}{|l|}{ Select European Markets } \\
\hline Greece & 186 & 72 & (3) & $(2.7)$ & 0.8 \\
\hline Ireland & 18 & 37 & 3 & 0.6 & 0.8 \\
\hline Italy & 18 & 50 & 19 & $(0.9)$ & 0.8 \\
\hline Portugal & 8 & 37 & 9 & (1.1) & 0.8 \\
\hline Spain & 5 & 32 & $(0.9)$ & 2.5 & 0.8 \\
\hline
\end{tabular}

()$=$ negative,$-=$ not available, bps $=$ basis points, $F X=$ foreign exchange.

Notes:

1. Data reflect changes between 30 December 2016 and 15 February 2017.

2. A positive (negative) value for the FX rate indicates the appreciation (depreciation) of the local currency against the United States dollar.

Sources: Bloomberg LP and Institute of International Finance (IIF).

account deficit in Q4 2016, an upgrade in the sovereign rating outlooks (Fitch Ratings in December 2016 and Moody's Investors Service in February 2017), expanding international reserves, and various policy reforms initiated by the government. Singapore saw a 10-bps decline in the 2-year bond yield and a 23-bps decline in the 10-year bond yield. The drops were partly driven by bolstered investor confidence as GDP growth accelerated to 2.9\% y-o-y in Q4 2016 from 1.2\% y-o-y in the third quarter of 2016. Malaysia also witnessed a decline in its 2-year and 10-year bond yields, partly due to strong demand from local investors despite a rise in inflation to $3.2 \%$ y-o-y and continued (but slowing) capital outflows in January.

The divergence in global growth prospects, risk outlooks, and monetary stances is driving international capital flows in different directions. Recent quarters have witnessed variations in foreign holdings across Asian bond markets (Figure B). At the end of Q4 2016, the share of foreign holdings in regional bond markets fell in Indonesia, Malaysia, and Thailand, following the US dollar's appreciation and consequent depreciation pressures on local currencies. Malaysia's foreign holdings share dropped the most, shedding more than 3 percentage points to
Figure B: Foreign Holdings of Local Currency Government Bonds in Select Asian Economies (\% of total)

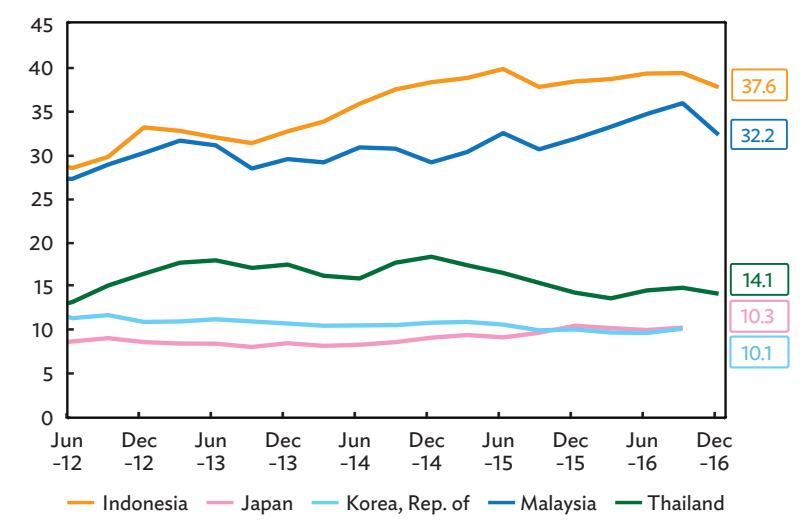

Note: Data as of end-December 2016 except for Japan and the Republic of Korea (end-September 2016).

Source: AsianBondsOnline.

$32.2 \%$ at the end of December. The share of foreign holdings in Indonesia slipped from $39.2 \%$ to $37.6 \%$ in the same period. However, neither Malaysia nor Indonesia experienced yield upticks as a result of a foreign sell-off. These markets have become more resilient to capital outflows due to solid economic fundamentals, increased 
demand from domestic market participants, improved investor profiles, and better-developed local currency bond markets following the implementation of the Asian Bond Markets Initiative. Even with the headwind of policy uncertainty in the US and political uncertainty in the eurozone, global capital flows have started to return to emerging East Asia in 2017. Foreign holdings in Indonesia inched up to $37.8 \%$ of the total at the end of January. In the Republic of Korea, after 5 consecutive months of foreign bond outflows, January saw the return of foreign inflows. Thailand also reported strong foreign inflows into its bond market in January.

As the monetary policies of major advanced economies have diverged, Asian financial markets have benefited from improved investor confidence and rising risk appetite. Consistent with the region's promising economic prospects, credit default swap spreads declined in all markets between 30 December and 15 February except for the Republic of Korea (Figure $\mathbf{C}$ ). The largest declines were seen in the Philippines and Viet Nam, with spreads in both markets shedding 23 bps. Malaysia's credit default swap spreads fell $21 \mathrm{bps}$, while spreads in the PRC and Indonesia shed 20 bps each.

In line with the upturn in the global economy and upbeat investor sentiment, the Volatility Index has been stable and EMBIG spreads and JP Morgan EMBI Sovereign Stripped Spreads both declined between

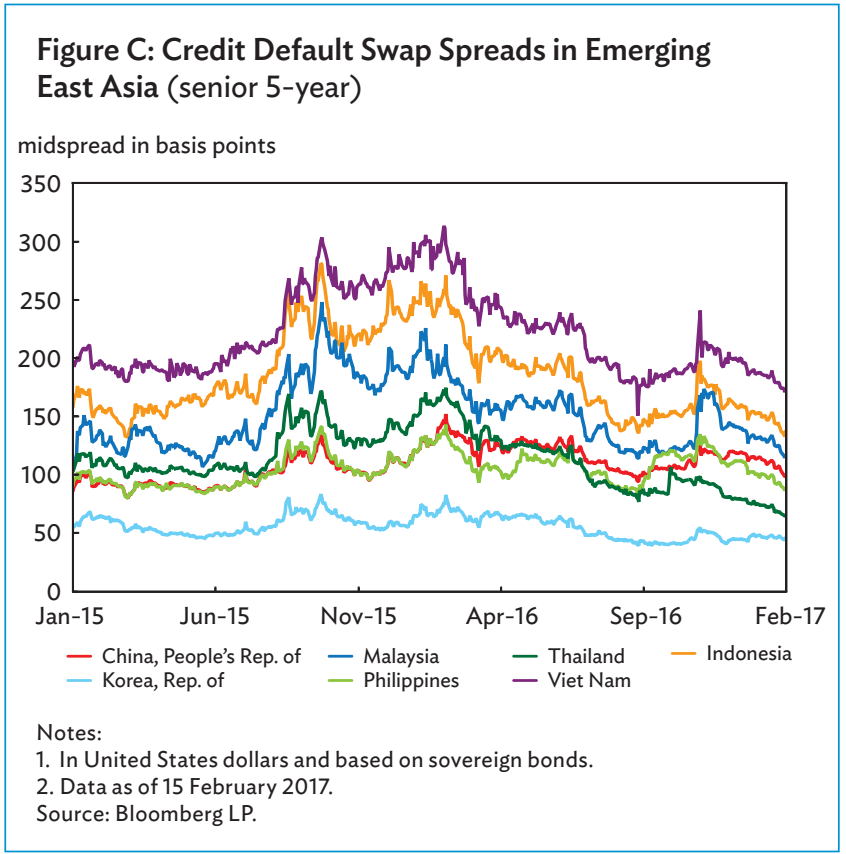

30 December and 15 February (Figures D, E). Equity markets also recovered across emerging East Asia during the review period, largely driven by healthier economic outlooks across the region. The biggest gains were seen in Hong Kong, China (9.1\%); Singapore (7.2\%); and Viet Nam (7.0\%) (Figure F). In Hong Kong, China, much of the recovery in the stock market was due to strong demand from PRC-based investors. Trade, however, weakened, with exports decreasing $1.2 \%$ y-o-y in January Figure D: United States Equities Volatility and Emerging
Market Sovereign Bond Spreads

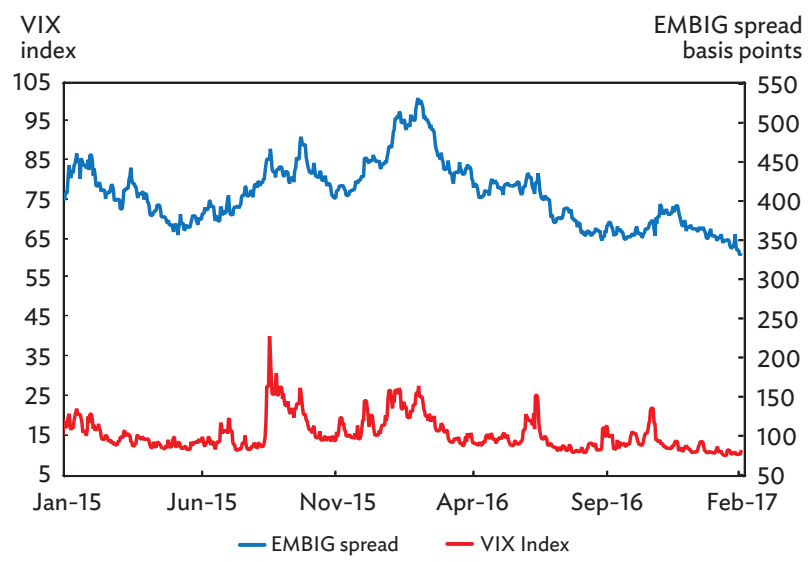

EMBIG = Emerging Markets Bond Index Global, VIX = Chicago Board Options Exchange Volatility Index.

Note: Data as of 15 February 2017.

Source: Bloomberg LP.

Figure E: JP Morgan Emerging Markets Bond Index Sovereign Stripped Spreads

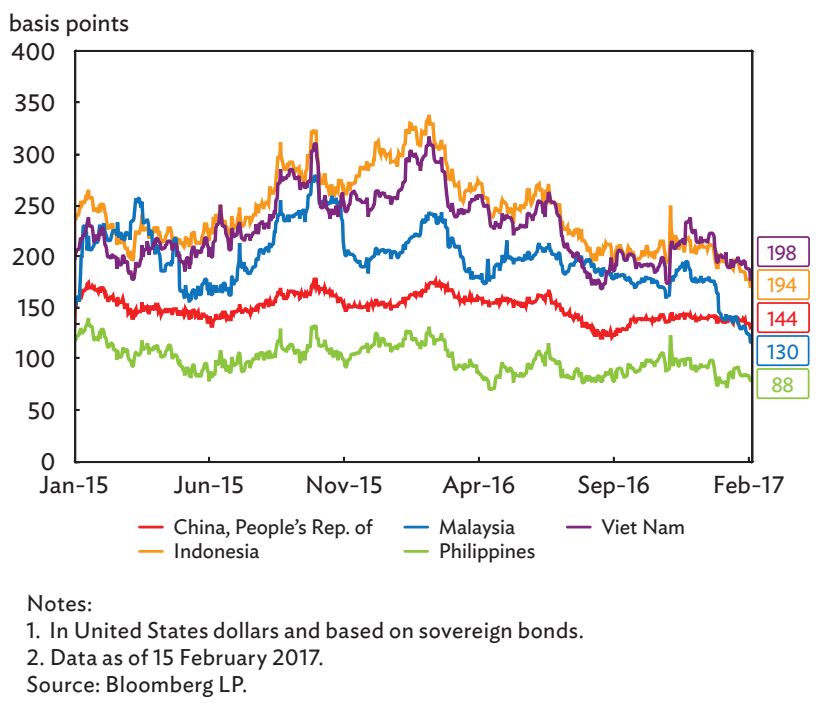


Figure F: Change in Equity Market Indexes in Emerging East Asia between 30 December 2016 and 15 February 2017 (\%)

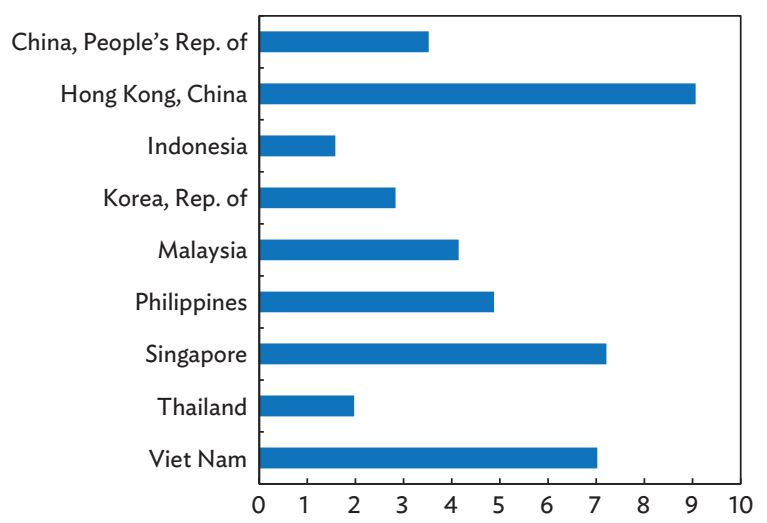

Note: The equity indexes used were Shanghai Stock Exchange Composite Index (People's Republic of China); Hang Seng Index (Hong Kong, China); Jakarta Composite Index (Indonesia); Korea Composite Stock Price Index (Republic of Korea); Kuala Lumpur Composite Index (Malaysia); Philippine Stock Exchange Index (Philippines); Straits Times Index (Singapore); Stock Exchange of Thailand (Thailand); and Vietnam Stock Index (Viet Nam). Source: Bloomberg LP.

from a $10.1 \%$ y-o-y increase in December. In Singapore, the GDP growth rate accelerated to $2.9 \%$ y-o-y in Q4 2016 from 1.2\% y-o-y in Q3 2016. In Viet Nam, GDP growth nudged up to 6.2\% y-o-y in Q4 2016 from 5.9\% in the previous quarter.

Underpinned by strengthening economic fundamentals, currencies in emerging East Asian markets have appreciated against the US dollar amid a backdrop of policy uncertainty in the US (Figure G). Among the region's economies, the Korean won gained the most between 30 December and 15 February, appreciating $5.6 \%$ during the review period, largely buoyed by positive capital inflows in January. The Thai baht also recovered some of its earlier losses, gaining $2.3 \%$ against the US dollar. The two exceptions were the Hong Kong dollar and Philippine peso, which weakened $0.05 \%$ and $0.6 \%$, respectively. The recovery in emerging East Asian currencies can be mainly attributed to improvements in economic outlook and investor sentiment. In markets such as Indonesia, the Republic of Korea, and Thailand, positive capital inflows at the start of 2017 also contributed to currency appreciation.

As the global economy starts to pick up, uncertainty will become a key theme for investors in 2017. Different
Figure G: Change in United States Dollar Value per Unit of Local Currency between 30 December 2016 and 15 February 2017 (\%)

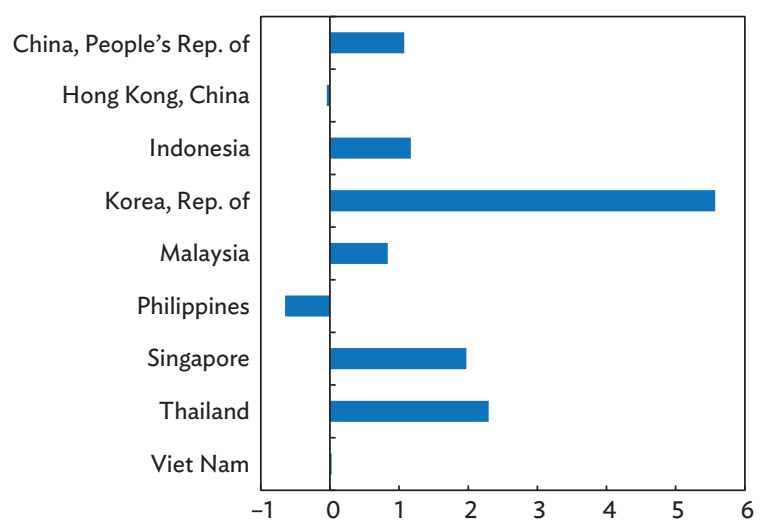

Note: A positive (negative) value for the foreign exchange rate indicates the appreciation (depreciation) of the local currency against the United States dollar.

Source: Bloomberg LP.

paces of recovery and varying economic outlooks are leading to divergences in monetary policies. The possible acceleration of rate hikes by the Federal Reserve may pose risks to emerging Asian financial stability (Box 1). ${ }^{7}$ With unemployment and inflation rates approaching policy targets, the market consensus is that the Federal Reserve will raise the federal funds rate more than once this year. Higher interest rates may cause global capital to flow out of emerging Asian markets and exert depreciation pressure on local currencies. Although many regional economies are adopting a wait-and-see approach and keeping their monetary policy stable, heightened depreciation pressures may push central banks to tighten their domestic monetary stance. Since many emerging Asian economies have rapidly built up foreign and local currency debt positions in the low interest rate environment prevailing after the global financial crisis, the possible tightening of liquidity could challenge their financial stability. Nevertheless, solid economic prospects and sufficient international reserves should cushion such shocks.

Another major source of risk is policy uncertainty in developed economies. Policy and political risks in the US and eurozone will influence the global economic outlook and become a key risk to emerging Asian financial markets (Box 2). Despite a global recovery, the prices of safe-haven assets such as gold remain robust during the review period, which reflects investor concerns

\footnotetext{
${ }^{7}$ Emerging Asia comprises the People’s Republic of China; Hong Kong, China; India; Indonesia; Republic of Korea; Malaysia; Philippines; Singapore; Taipei,China; Thailand; and Viet Nam.
} 
about possible policy risks in advanced economies and the sustainability of their economic recoveries.

In the US, policy uncertainty may have not been fully priced into asset prices. Changes in trade policy could trigger tensions with major trade partners, which would not only hurt US exports but also raise US inflation due to higher prices of goods. A fiscal stimulus package based on tax cuts and infrastructure investments is still subject to a great deal of uncertainty and has yet to be spelled out clearly. While stimulus would benefit growth, it might also unleash inflationary pressures, which would in turn influence the Federal Reserve's monetary policy and cause accelerated rate hikes and US dollar appreciation. Asian financial markets may further adjust and price in these risks in the future, which would exacerbate volatility.

The eurozone will see several elections in major economies in 2017. The United Kingdom is aiming to invoke Article 50 of the Lisbon Treaty by the end of March, although the timing and outcome of Brexit negotiations between the United Kingdom and the European Union remains unclear. The series of elections in some European economies and possible changes in economic policies of new governments in the eurozone may threaten the sustainability of Europe's budding recovery. The eurozone still faces major unsolved problems such as Greece's sovereign debt and the Italian banking sector's fragility, which further add to the vulnerability of the eurozone's recovery. Under this cloud of global political and policy uncertainty, Asian financial market might become more volatile and the demand for safe-haven assets such as precious metals and highly rated sovereign bonds could surge.

\section{The Chinese yuan's depreciation also poses potential} risks to the economies and financial markets of Asia (Box 3). A weaker yuan might curb the exports of Asia to the PRC, the region's largest trade partner, and intensify competition for exports to the US and other economies. In the unlikely case that the yuan's depreciation accelerates, capital may flow out of the PRC and pull down asset prices, which would weaken the balance sheets of financial institutions and challenge highly leveraged investors in the PRC. Negative investor sentiment could also spill over to other Asian markets, leading to capital outflows from the region.

\section{Box 1: Emerging Asia's Financial Stability amid the Latest Round of Interest Rate Hikes in the United States}

The latest round of United States (US) interest rate hikes, which began in December 2015, accelerated in recent months with 25-basis-point hikes in both December 2016 and March 2017. The recent release of US economic data points to a robust economy. Nonfarm payroll growth surpassed expectations and unemployment remains low. ${ }^{a}$ The core Consumer Price Index, excluding food and energy, rose 2.2\% year-on-year ( $y-0-y$ ) in February 2017. b Solid labor market conditions and improvements in inflation suggest upbeat growth prospects, which may lead to one or two more rate hikes in 2017. ${ }^{c}$

\section{Uncertainty in the International and Domestic Liquidity Environments}

A strong US dollar attracts international capital flows. The gradual normalization of monetary policy and robust economic performance in the US provide support to the US dollar. Despite the retreat of the US dollar index in January 2017, the US dollar still enjoys solid economic

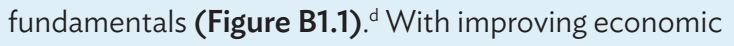
prospects, international capital will flow back to US dollardenominated assets, placing downward pressure on asset prices in emerging Asia. International capital flows are

\footnotetext{
a $h$ ttps://www.bls.gov/news.release/pdf/empsit.pdf

b https://www.bls.gov/news.release/cpi.nrO.htm

Details available at http://www.cmegroup.com/trading/interest-rates/countdown-to-fomc.html

¿ Real trade-weighted US dollar value and nominal US effective exhange rate.

e Emerging Asia comprises the People's Republic of China; Hong Kong, China; India; Indonesia; Republic of Korea; Malaysia; Philippines; Singapore; Taipei,China; Thailand; and Viet Nam.
} 


\section{Box 1: Emerging Asia's Financial Stability amid the Latest Round of Interest Rate Hikes in the United States continued}

\section{Figure B1.1: Federal Funds Target Rate and the Value of the United States Dollar}

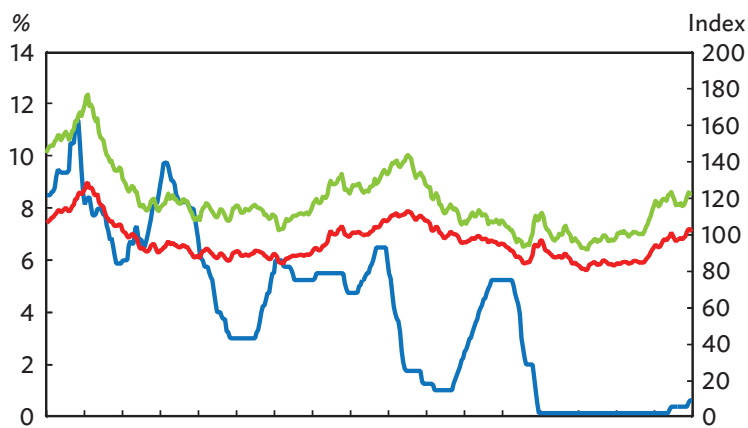

Jan Jan Jan Jan Jan Jan Jan Jan Jan Jan Jan Jan Jan Jan Jan Jan Jan Jan $-83-85-87-89-91-93-95-97-99-01-03-05-07-09-11-13-15-17$

\section{- Monthly average federal funds target rate (LHS) \\ - Real trade-weighted value of the US dollar (RHS) \\ - Nominal US effective exchange rate (RHS)}

LHS = left-hand side, RHS = right-hand side, US = United States. Note: Monthly average federal funds target rate and real trade-weighted value of the US dollar data are as of February 2017; nominal US effective exchange rate data is as of January 2017.

Sources: Haver Analytics and Bank for International Settlements.

sensitive to the US dollar exchange rate. When the US dollar index was low before 2014, emerging Asia experienced net capital inflows; when the US dollar started to rise in the second half of 2014, emerging Asia witnessed net capital outflows (Figure B1.2). More interest rate hikes in the US could further drain foreign investment from emerging Asia.

Emerging Asia also faces uncertainty concerning the domestic monetary stances of many regional economies that have been lowering policy rates over the past 2 years to support investment and growth. A tightening monetary stance in the US might spillover to emerging economies, especially those which have open capital accounts and flexible exchange rates. If currency depreciation pressures gain momentum, central banks may adjust domestic monetary policies in line with the Federal Reserve. Since policy rates in emerging Asia are strongly correlated with one another due to common external shocks and growing regional integration, rising interest rates may adversely affect the region's liquidity environment (Figure B1.3).

\section{Increased Leverage in Emerging Asia in a Low Interest Rate} Environment

Emerging Asia has witnessed a rapid expansion of leverage in both the public and private sectors in recent years. Rising
Figure B1.2: Capital Flows in Emerging Asia

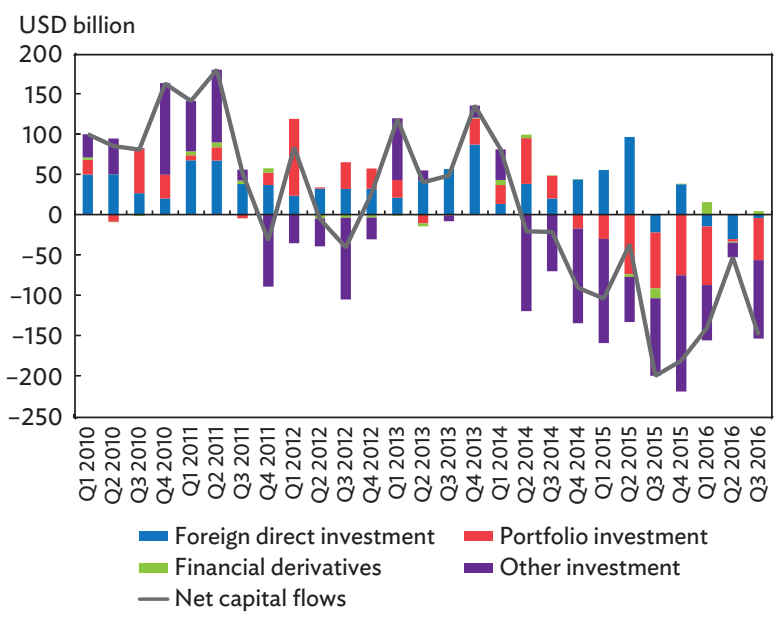

$\mathrm{Q} 1$ = first quarter, $\mathrm{Q} 2$ = second quarter, $\mathrm{Q} 3$ = third quarter, $\mathrm{Q} 4$ = fourth quarter, USD = United States dollar.

Note: Emerging Asia comprises the People's Republic of China; Hong Kong,

China; India; Indonesia; the Republic of Korea; Malaysia; the Philippines;

Singapore; Taipei,China; Thailand; and Viet Nam.

Source: Haver Analytics.

\section{Figure B1.3: Policy Rates in Emerging Asia}

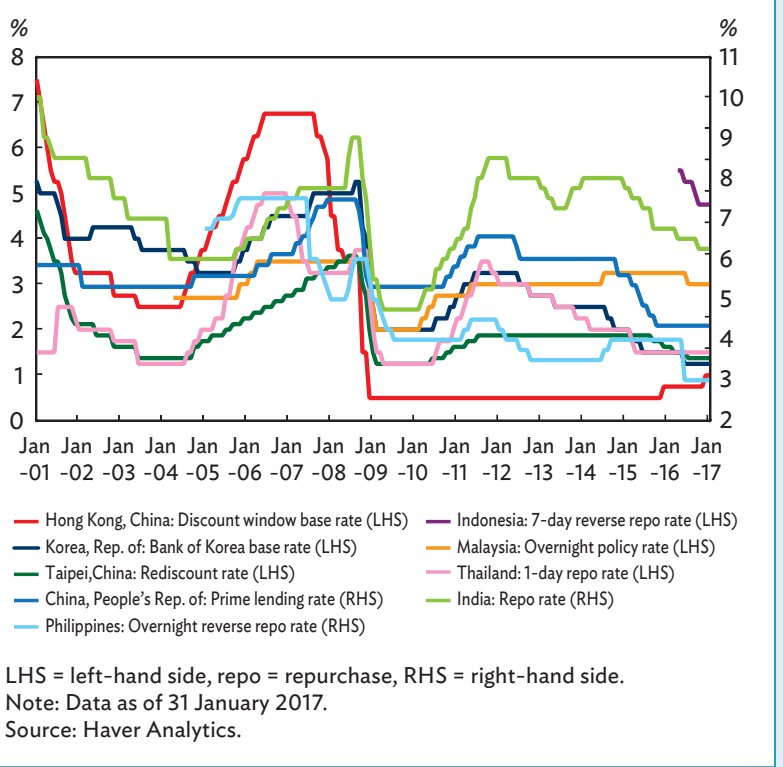

leverage poses several types of risks. The first risk is a currency mismatch associated with surging foreign currency (FCY) debt. Global monetary easing and a weak US dollar between 2010 and 2014 triggered burgeoning FCY debt in emerging Asia. 


\section{Box 1: Emerging Asia's Financial Stability amid the Latest Round of Interest Rate Hikes in the United States continued}

During the period 2010-2016, the outstanding amount of FCY debt in emerging Asia doubled, with corporate debt increasing by more than $150 \%$ (Figure B1.4). The rapid expansion of FCY debt exacerbates currency mismatches, which arise when domestic corporates generate profits in local currencies but repay principal and interest in foreign currencies. Heightened FCY exposure may pose a risk when the local currency depreciates in the face of US interest rate hikes.

Growing domestic leverage also increases the risk exposure to interest rate hikes. Amid an accommodative monetary environment since 2012, emerging Asia's domestic leverage levels have been increasing, especially in the private sector. In terms of direct financing, the aggregate amount of outstanding corporate bonds in select emerging Asian economies rose 280\% from 2008 until 2016, while outstanding government bonds rose $139 \%$ over the same period (Figure B1.5a). In terms of indirect financing, bank credit extended to the private nonfinancial sector continued to expand in many emerging Asian economies (Figure B1.5b). Higher interest rates would decrease the value of these debt assets and challenge financial stability.

\section{Figure B1.4: Outstanding Foreign Currency Debt in Select Emerging Asian Economies}

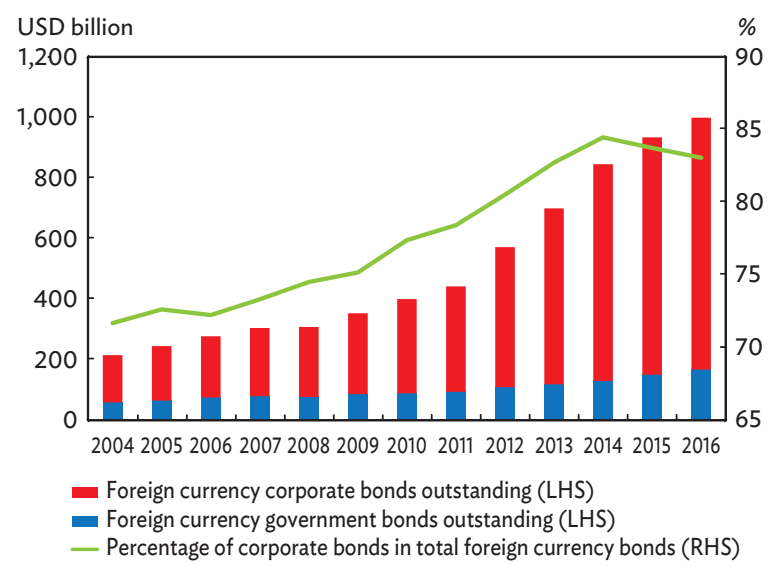

LHS = left-hand side, RHS = right-hand side, USD = United States dollar. Notes:

1. Emerging Asia data available for the People's Republic of China; Hong Kong, China; Indonesia; the Republic of Korea; Malaysia; the Philippines; Singapore; Thailand; and Viet Nam.

2. Data are year-end figures except for 2016 (end-June).

Source: AsianBondsOnline.

\section{Figure B1.5a: Outstanding Local Currency Debt in Select Emerging Asian Economies}

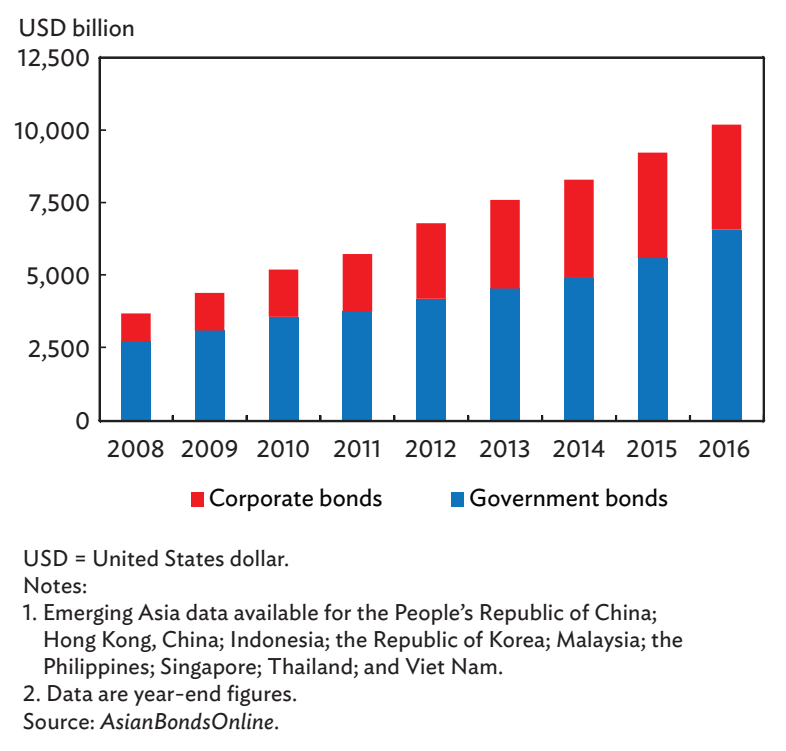

Figure B1.5b: Bank Credit Extended to the Private Nonfinancial Sector (share of GDP)

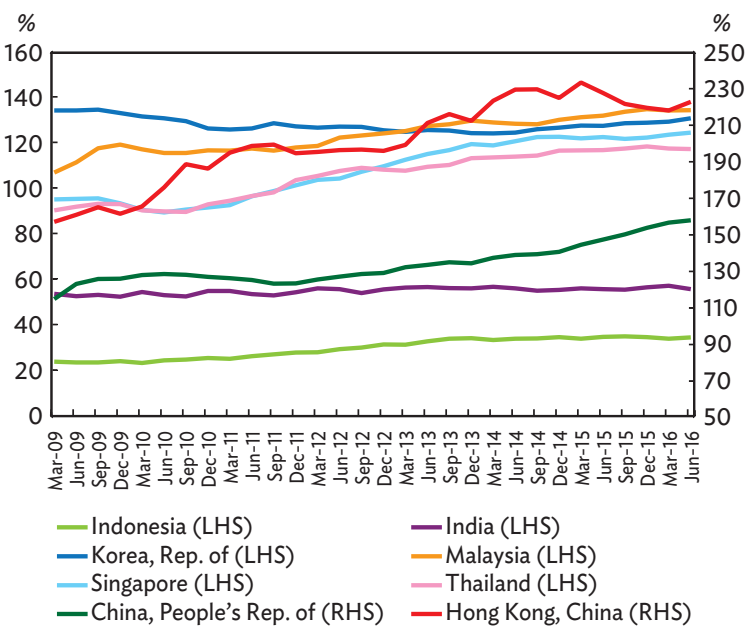

GDP = gross domestic product, $\mathrm{LHS}=$ left - hand side, $\mathrm{RHS}=$ right-hand side . Source: Bank for International Settlements. 


\section{Box 1: Emerging Asia's Financial Stability amid the Latest Round of Interest Rate Hikes in the United States continued}

Moderation in economic growth might also heighten default risks across the region. Nonperforming loan ratios have increased in some emerging Asian economies since 2012, which is ringing alarm bells across the region (Figure B1.6a). Widened credit spreads also reflect concerns of default risk as investors claim higher premiums to cover growing risks (Figure B1.6b).

\section{Risks are Manageable in the Short-Term; Prudent Measures are Needed in the Long-Term}

Emerging Asia may be exposed to potential risks in an uncertain liquidity environment, but the risks are still manageable in the short-term.

There is policy uncertainty in the US. Despite a strong economic performance, the US dollar weakened slightly in January 2017, partly due to concerns about policy uncertainty. Fiscal stimulus may face resistance in an environment of rising interest rates. Rapid increases in interest rates would exacerbate the fiscal burden of the US government, especially with tax cuts looming. In addition, an excessively strong US dollar could harm exports and curb economic growth.

Emerging Asian economies may not tighten their monetary stance soon. According to the Asian Development Outlook

\section{Figure B1.6a: Bank Nonperforming Loans as a Share of Total Gross Loans}

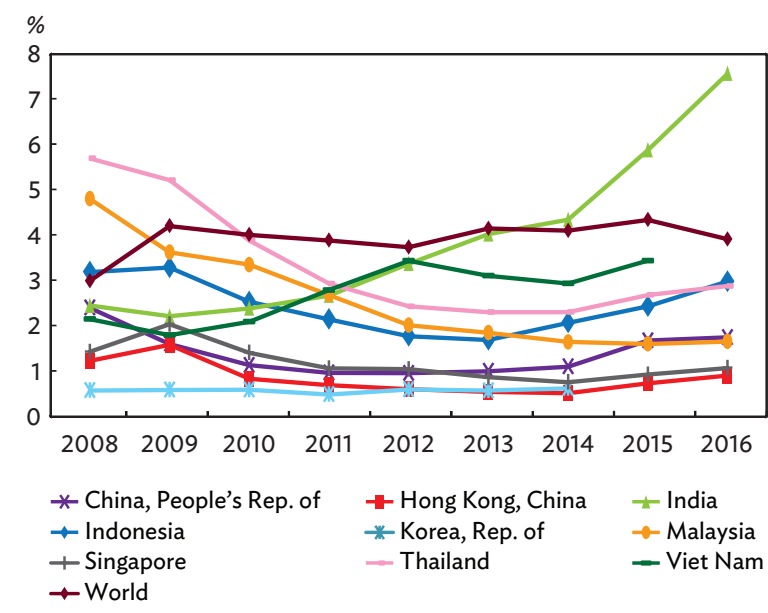

Sources: World Bank's World Development Indicators and the International Monetary Fund's Global Financial Stability Report.
Supplement-December 2016, developing Asia's economic growth is expected to slightly pick up to $5.7 \%$ in 2017 from $5.6 \%$ in 2016. With economic growth still fragile in light of global uncertainties, Asian central banks may exercise caution before tightening monetary policies. The subdued economic outlook also may not support an uptick in financing costs. Meanwhile, discrepancies in monetary policies among major developed economies indicate that global monetary easing may not end soon. ${ }^{8}$ Thus, a combination of domestic and external factors suggest that the region's liquidity environment will remain stable over the short-term.

Emerging Asia is maintaining healthy economic growth and enjoying relatively strong macroeconomic fundamentals such as large foreign reserves. Robust growth and fundamentals, aided by relatively sound prudential regulation and (in some cases) macroprudential policies, will protect emerging Asia from external shocks in the short-term. However, in light of the latent danger posed by the region's growing debt, prudential measures that gradually control leverage levels-especially in less-efficient sectors and industries suffering from overcapacitycan facilitate the region's structural transformation and upgrading, and contribute to greater resilience in the long-term.

\section{Figure B1.6b: Credit Spreads between Government Bonds and 3-Year BBB Corporate Bonds}

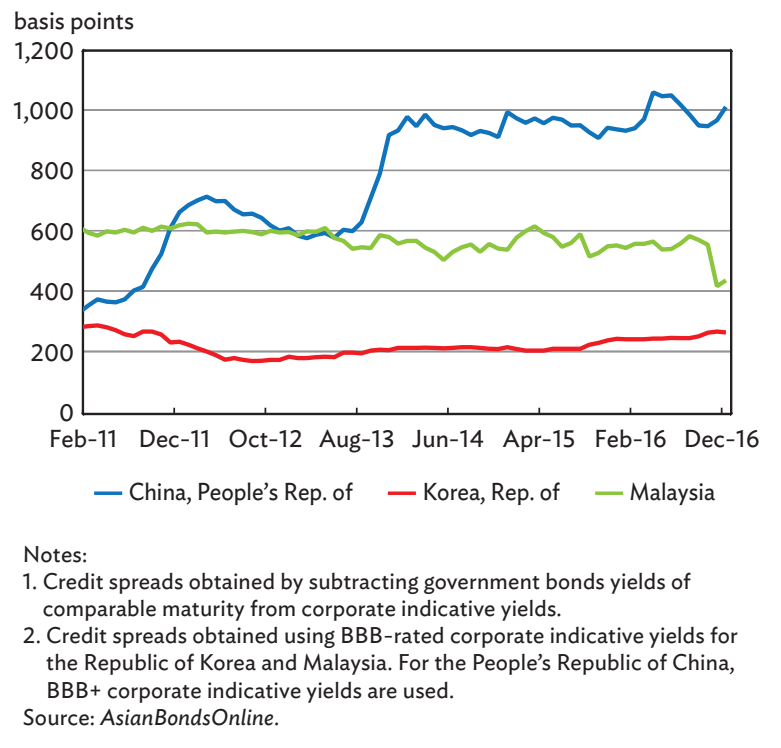

Developing Asia comprises the 45 regional developing member economies of the Asian Development Bank. https:/www.adb.org/sites/default/files/publication/216421/ado -supplement-dec-2016.pdf

$g$ At their recent monetary policy meetings, the Bank of Japan and the European Central Bank both indicated that they would keep interest rates steady and maintain existing quantitative easing programs over the short-term. http://www.boj.or.jp/en/announcements/release_2017/k170131a.pdf and https:/www.ecb.europa.eu/press/pr/date/2017/html/ pr170119.en.html 


\section{Box 2: Asian Financial Markets Under a Cloud of Policy Uncertainty}

The year kicked off with signs of moderate economic recovery in major developed economies. In the United States (US), the Consumer Price Index (CPI) recorded a $0.6 \%$ month-on-month ( $\mathrm{m}-\mathrm{o}-\mathrm{m})$ increase in January, the largest gain since February 2013. ' Sales for retail and food services rose $0.4 \% \mathrm{~m}-\mathrm{o}-\mathrm{m}$ in January, while total business sales saw a m-o-m increase of $2.0 \%$ in December 2016 . $^{\text {b }}$

In the eurozone, the All-Items Harmonised Indices of Consumer Prices increased 1.8\% y-o-y in January, a 4-year high. The eurozone's unemployment rate of $9.6 \%$ in December 2016 and January 2017 were the lowest since May 2009. . At the same time, core inflation in the eurozone remained low and the region's $0.4 \%$ quarter-onquarter gross domestic product growth rate for the fourth quarter of 2016 was slightly lower than expectations. ${ }^{d}$ The eurozone also saw $1.6 \% \mathrm{~m}-\mathrm{o}-\mathrm{m}$ and $0.3 \% \mathrm{~m}-\mathrm{o}-\mathrm{m}$ decreases in industrial production and retail trade volume, respectively, in December 2016. ${ }^{\text {e }}$

In Japan, the annual CPI increase in December 2016 was $0.3 \%$. The Bank of Japan expects the CPI to increase at a pace of $1.7 \%$ y-o-y by fiscal year 2018, which would be close to the central bank's annual target level of $2.0 \%$. Japan's real gross domestic product growth forecast was raised from $1.0 \%$ to $1.4 \%$ for fiscal year 2016 and from $1.3 \%$ to $1.5 \%$ for fiscal year 2017 . $^{\text {}}$

A somewhat more robust recovery in the US than in the eurozone and Japan is causing monetary policies to diverge. The US Federal Reserve is expected to hike policy rates two or three times in 2017, while the European Central Bank and the Bank of Japan will retain their respective quantitative easing programs. Notwithstanding heterogeneity in the speed of economic recovery among major developed economies, their overall economic prospects are positive. Yet, looming political and policy uncertainties in developed economies pose potential downside risks. Concerns over these uncertainties are engendering momentum for safehaven assets such as precious metals. Gold prices, for example, increased following the Federal Reserve's rate hike in December 2016, which was at odds with conventional price patterns (Figure B2.1).
Given the region's healthy economic outlook, emerging Asian financial markets have become more attractive amid global political and policy uncertainty. Since the beginning of 2017, major emerging Asian currencies have appreciated against the US dollar and regional stock markets have risen tangibly (Figures B2.2a, B2.2b). Over the course of 2017,

\section{Figure B2.1: Standard and Poor's Goldman Sachs Commodity Index Gold Total Return Index (close price)}

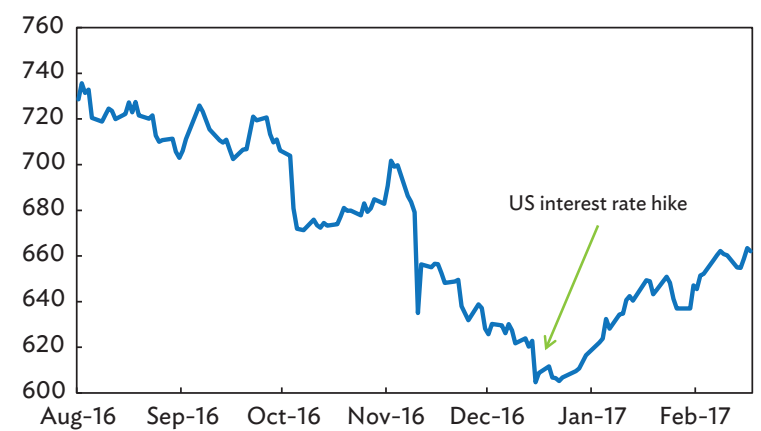

US $=$ United States.

Note: Data as of 17 February 2017

Source: Wind Information.

Figure B2.2a: Change in United States Dollar Value per Unit of Local Currency between 31 December 2016 and 31 January 2017 (in \%)

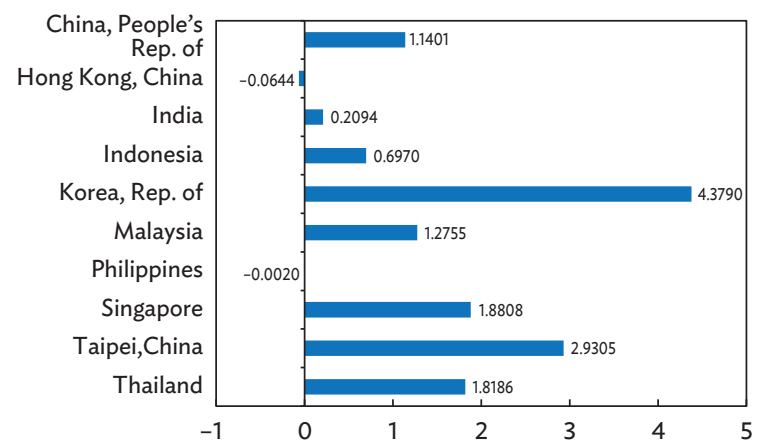

Note: A positive (negative) value means the appreciation (depreciation) of the local currency relative to the United States dollar. Source: Haver Analytics.

\footnotetext{
a https://www.bls.gov/news.release/cpi.nro.htm

b https://www.commerce.gov/economicindicators, http://www.census.gov/retail/marts/www/marts_current.pdf, http://www.census.gov/mtis/www/data/pdf/mtis_current.pdf http://ec.europa.eu/eurostat/news/news-releases

In January, $y$-o-y core inflation (exclusive of energy and unprocessed food) in the eurozone was 0.9\%, which was the same as December 2016 and 0.1 percentage point lower than in January 2016. http://ec.europa.eu/eurostat/documents/2995521/7885873/2-22022017-AP-EN.pdf/67b105f6-fd32-4685-ac1d-62e7a394eca1

e http://ec.europa.eu/eurostat/documents/2995521/7868348/2-14022017-BP-EN.pdf/da0c1c33-2d80-4cc2-9f34-de2dab92aac5, http://ec.europa.eu/eurostat/ documents/2995521/7868318/4-14022017-AP-EN.pdf/d735ee06-3a57-4078-9e2d-e54237b2e374, http://ec.europa.eu/eurostat/documents/2995521/7851535/4-03022017 -AP-EN.pdf/0ac0511e-b858-472d-828e-606c58d0ba7a

http://www.stat.go.jp/english/data/cpi/1581.htm, http://www.boj.or.jp/en/mopo/outlook/gor1701b.pdf

g Emerging Asia comprises the People's Republic of China; Hong Kong, China; India; Indonesia; the Republic of Korea; Malaysia; the Philippines; Singapore; Taipei,China; Thailand; and Viet Nam.
} 


\section{Box 2: Asian Financial Markets Under a Cloud of Policy Uncertainty continued}

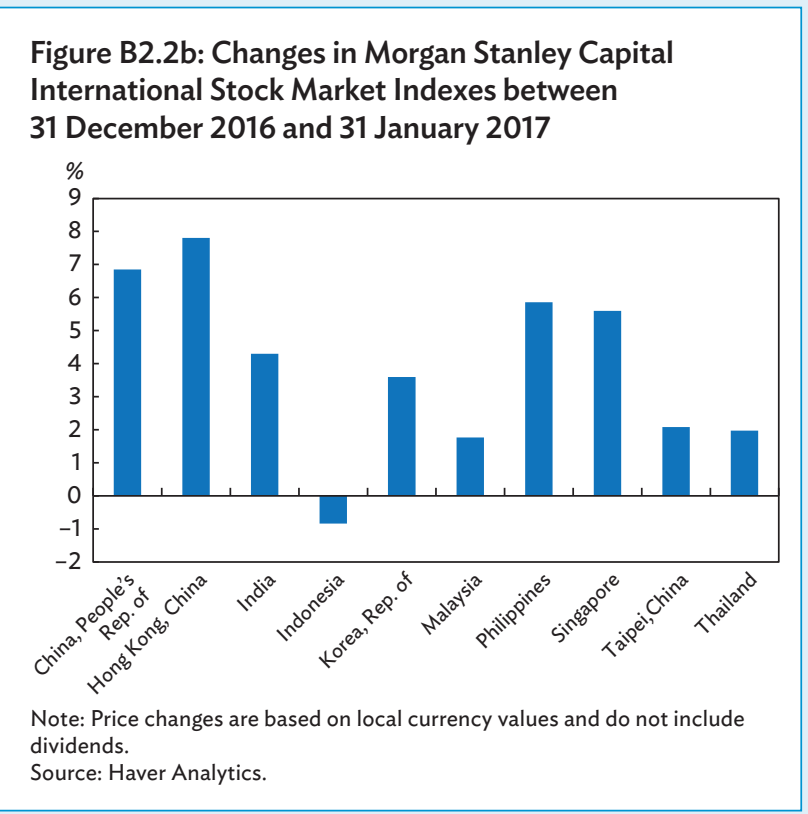

on the other hand, major political and policy events in the US and eurozone may influence emerging Asian financial markets in different ways.

\section{Policy Uncertainty in the United States}

The trade policy and fiscal stimulus of the new US administration has generated a great deal of interest and uncertainty. It is not yet clear how the new administration's approaches to trade and spending will evolve. Changes in trade policy would influence emerging Asia's growth, though the shocks could be mitigated. While its fiscal stimulus package lacks clarity at present, its mere airing has improved investment sentiment and risk appetite in the US. Such ebullience might spill over into emerging Asian financial markets.

Changes in trade policy could trigger trade tensions and conflict between the US and its major Asian trade partners. Many emerging Asian economies run trade surpluses with the US and therefore any change in trade policy would affect the region's exports and growth, and hit the earnings of many export-oriented corporations (Figure B2.3a). However, the multilateral World Trade Organization framework makes it difficult for members to unilaterally erect high tariffs and pursue other measures. Emerging Asian economies also have a long history of coping with tariff and nontariff barriers. Futhermore, many emerging Asian economies, especially members of the

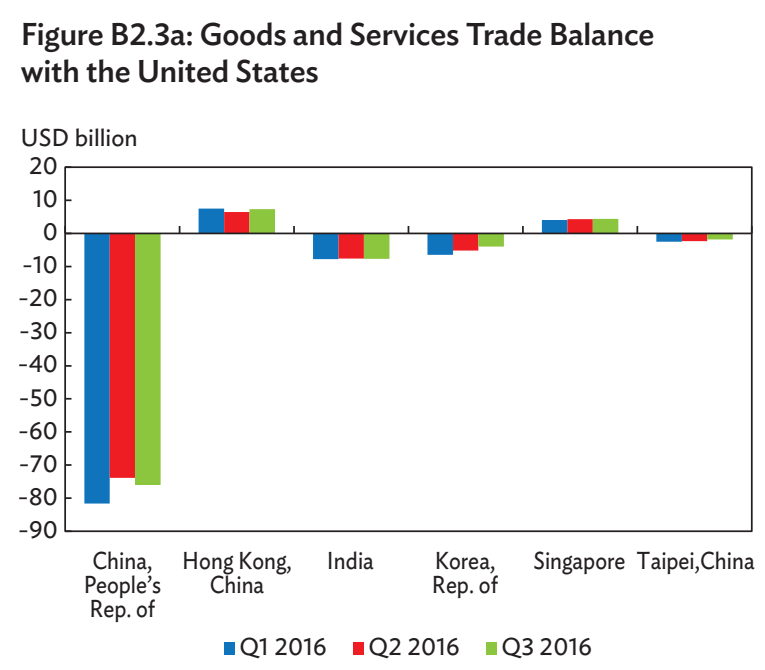

Q1 = first quarter, Q2 = second quarter, Q3 = third quarter, USD = United States dollar.

Source: Haver Analytics.

Figure B2.3b: Breakdown of Exports as Shares of Total Exports (\%)

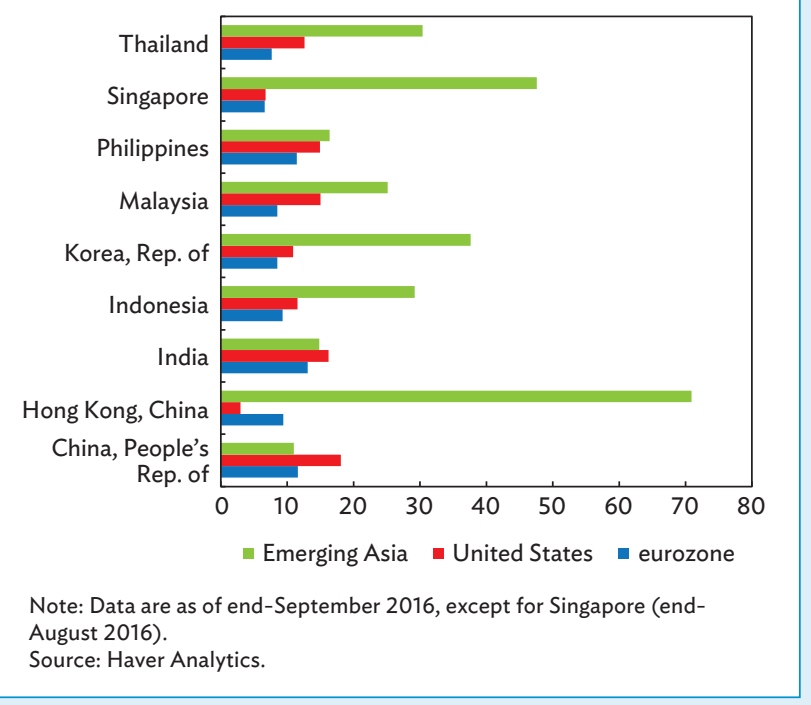

Association of Southeast Asian Nations, trade increasingly with regional partners (Figure B2.3b). There may also be resistance within the US against trade policy changes, including measures directed at manufactured goods from emerging Asia, which would raise prices and thus reduce the purchasing power of US households. Therefore, the magnitude of a US trade shock on emerging Asia may be more limited than widely feared. 


\section{Box 2: Asian Financial Markets Under a Cloud of Policy Uncertainty continued}

On the fiscal front, the US administration has proposed a stimulus package to boost domestic growth. Plans include individual and corporate tax cuts as well as large-scale infrastructure investments. Once approved by Congress, these tax cuts and infrastructure investments will bolster demand. A possible downside risk is a spike in inflation given the tightening labor market, which could accelerate the interest rate hike cycle and curb investments.

Despite the lack of detail about the magnitude, composition, and implementation of a fiscal stimulus package, the positive economic outlook has improved investor sentiment and risk appetite (Figures B2.4a, B2.4b). The Sentix Investor Confidence Index has surged more than $80 \%$ since November 2016 and over the past 3 months the Standard

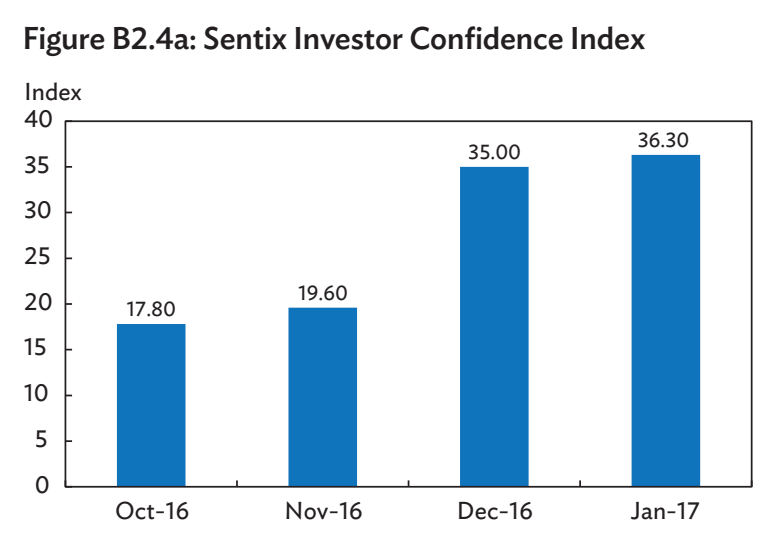

Source: Wind Information.

\section{Figure B2.4b: Price Trends in United States Equity} and Bond Markets

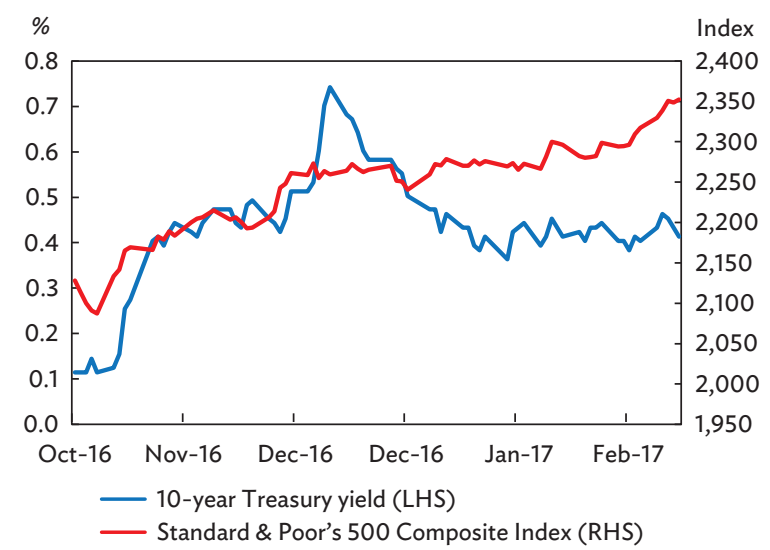

Note: Data as of 17 February 2017.

Source: Wind Information. and Poor's 500 Composite Index has gained 7.5\%. Yields on 10-year US Treasury bonds initially climbed after November's election result on expectations of a stronger US economy and tightened monetary stance, before sliding due to heightened policy uncertainty. Improved investment sentiment could spill over to emerging Asian financial markets by pushing down bond prices. However, concerns over rising inflation and a tighter liquidity environment might raise bond yields in emerging Asia, leading to a mixed picture. (Figure B2.5).

\section{Figure B2.5: Yields on 10-Year Government Bonds in Select Emerging Asian Bond Markets}

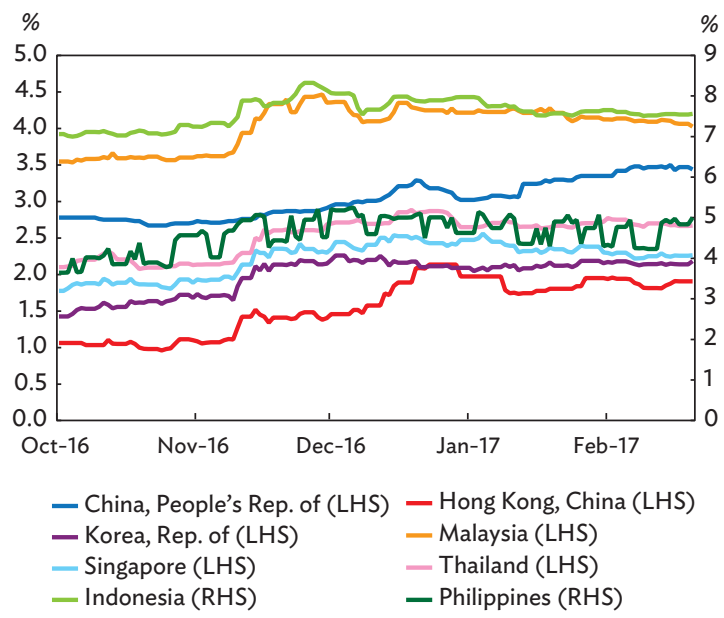

LHS = left-hand side, $\mathrm{RHS}=$ right-hand side

Note: Data as of 20 February 2017.

Source: Bloomberg LP.

\section{Political Risks in the Eurozone}

Notwithstanding signs of economic recovery, political uncertainty in the eurozone will be a major investment concern in 2017 as it tends to increase demand for less risky assets. Specific sources of uncertainty include negotiations over the terms of the United Kingdom's exit from the European Union and elections in a number of European economies (Table B2). New administrations of these European economies may shift the current policy agenda and influence the pace of recovery.

Recent opinion polls reveal the weakening of pro-European Union sentiment across the continent, further exacerbating political uncertainty. The possibility of changes in economic policies challenges the sustainability of economic recovery by adversely affecting business confidence, consumer confidence, demand, and growth. Despite some promising 


\section{Box 2: Asian Financial Markets Under a Cloud of Policy Uncertainty continued}

Table B2: Key Political Events in the Eurozone, 2016-2017

\begin{tabular}{|c|c|c|}
\hline Date & Event & Results \\
\hline Jun 2016 & $\begin{array}{l}\text { UK referendum on } \\
\text { EU membership }\end{array}$ & $\begin{array}{l}\text { The UK voted to leave } \\
\text { the EU by } 52 \% \text { to } 48 \% \text {. }\end{array}$ \\
\hline Dec 2016 & $\begin{array}{l}\text { Italian referendum on } \\
\text { constitutional reform }\end{array}$ & $\begin{array}{l}\text { Italy voted to reject } \\
\text { constitutional reform by } \\
59 \% \text { to } 41 \% \text {. Prime Minister } \\
\text { Matteo Renzi resigned. }\end{array}$ \\
\hline Feb-Mar 2017 & $\begin{array}{l}\text { The UK Parliament voted } \\
\text { on a bill to formally start } \\
\text { Brexit negotiations by } \\
\text { invoking Article } 50 \text { of } \\
\text { the Lisbon Treaty }\end{array}$ & $\begin{array}{l}\text { The UK Parliament passed } \\
\text { the bill to invoke Article } 50 \\
\text { of the Lisbon Treaty. }\end{array}$ \\
\hline Mar 2017 & $\begin{array}{l}\text { General election in } \\
\text { the Netherlands }\end{array}$ & $\begin{array}{l}\text { Mark Rutte's party won the } \\
\text { election. }\end{array}$ \\
\hline $\begin{array}{l}\text { Apr } 2017 \\
\text { May } 2017\end{array}$ & $\begin{array}{l}\text { Presidential election } \\
\text { in France }\end{array}$ & \\
\hline Oct 2017 & $\begin{array}{l}\text { General election } \\
\text { in Germany }\end{array}$ & \\
\hline
\end{tabular}

$\mathrm{EU}=$ European Union, UK = United Kingdom.

Source: AsianBondsOnline compilation.

signs of economic recovery in the eurozone, mounting policy risks partly contributed to the European Central Bank's decision to extend its quantitative easing program until December 2017. Both the euro exchange rate and
Figure B2.6: Exchange Rate and Benchmark 10-Year Government Bond Yields in the Eurozone

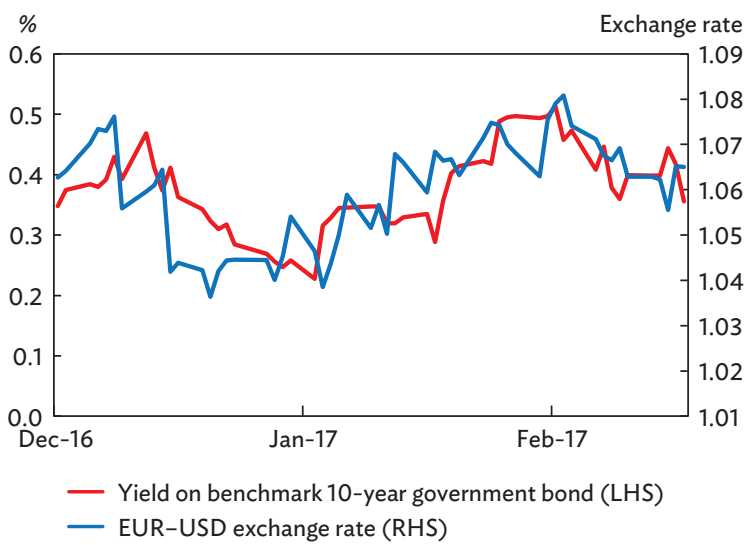

Note: Data as of 17 February 2017.

EUR = euro, $\mathrm{LHS}=$ left-hand side, $\mathrm{RHS}=$ right-hand side, USD = United States dollar.

Source: Wind Information.

yields on 10-year government bonds fell in February 2017 (Figure B2.6). Further political uncertainty in the eurozone may increase demand for safe-haven assets like precious metals and highly rated sovereign bonds. 


\section{Box 3: The Impact of the Chinese Yuan's Depreciation}

Over the past 12 months, the Chinese yuan has depreciated against the currencies of all major developed economies as well as many Asian currencies (Figure B3.1a). Given the People's Republic of China's (PRC) economic weight in Asia, the yuan's depreciation poses potential risks to the region's economies and financial markets. The yuan's depreciation also poses a risk to the PRC's financial stability, especially if its depreciation were to gain speed.

The depreciation of the yuan might adversely affect the exports of Asian economies to the PRC, with the impacts most pronounced in East and Southeast Asian economies that trade heavily with the PRC. On the other hand, since the PRC imports a significant amount of parts and components from East and Southeast Asian economies for final assembly and export, these economies would also partially benefit from increased Chinese exports driven by the depreciation of the yuan. The impact on other Asian economies that trade less with the PRC, such as India, would be more subdued (Figure B3.1b).

Asian exporters that compete with the PRC's exporters in markets such as the United States (US) would lose a degree of competitiveness due to a weaker Chinese yuan. The magnitude of the loss would depend on the relative depreciation of the exporter's currency vis-à-vis the yuan (Figure B3.2). For example, the extent to which manufacturing exporters in the Republic of Korea would

Figure B3.1a: Chinese Yuan versus Selected Currencies between 28 February 2016 and 27 February 2017 (\%)

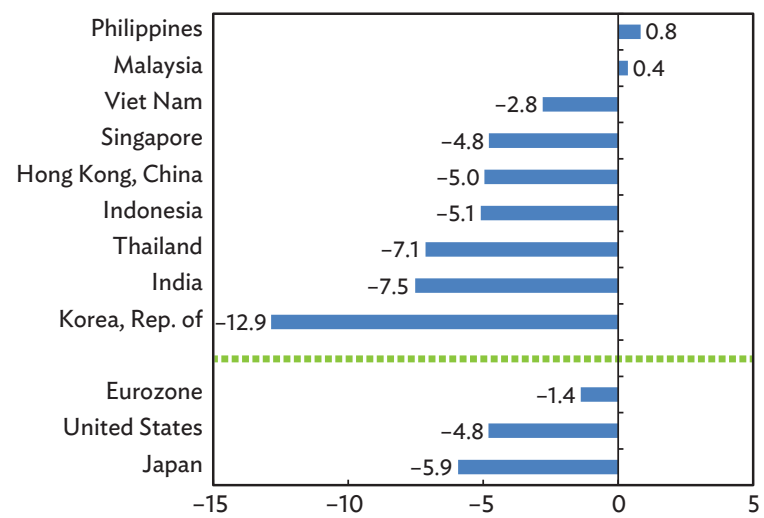

Note: A positive (negative) value means the appreciation (depreciation) of the Chinese yuan relative to other currencies. Source: Bloomberg LP.
Figure B3.1b: Exports to the People's Republic of China as Share of Total Exports, 2015 (\%)

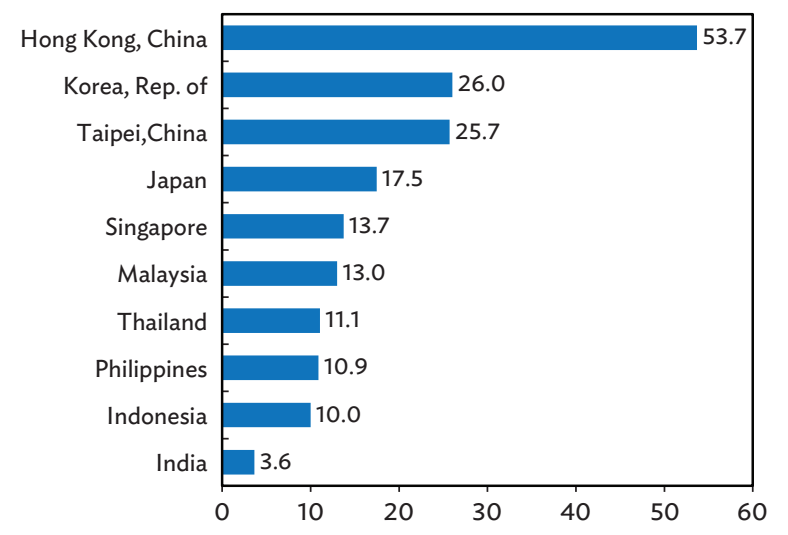

Sources: International Monetary Fund Direction of Trade Statistics and CEIC.

be impacted would depend on the relative depreciation of the won-dollar versus the yuan-dollar exchange rate. The competitiveness effects would be felt most strongly in East and Southeast Asian economies with significant exports of manufactured goods to the US and other markets in common with PRC exporters. In principle, this could raise the specter of competitive devaluation among regional currencies.

Figure B3.2: Change in United States Dollar Value per Unit of Local Currency between 1 January 2016 and 15 February 2017 (\%)

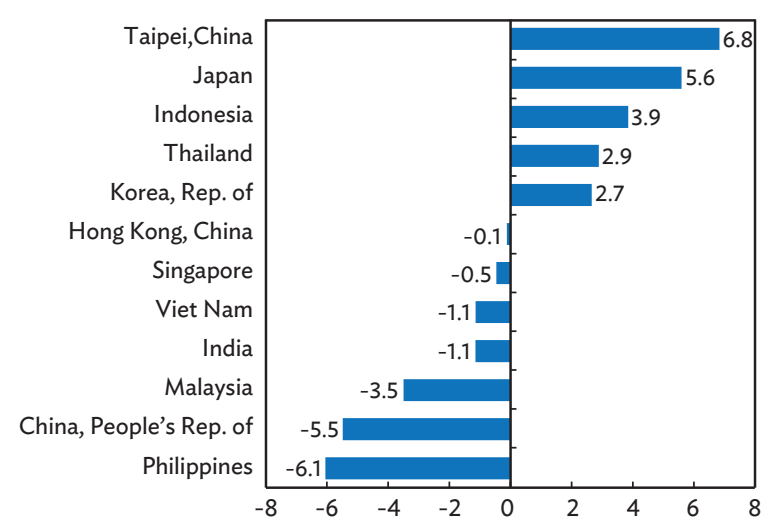

Note: A positive (negative) value means the appreciation (depreciation) of the local currency relative to the United States dollar. Source: Bloomberg LP. 


\section{Box 3: The Impact of the Chinese Yuan's Depreciation continued}

There is a risk that the depreciation of the yuan against the US dollar will further widen the US's bilateral trade deficit with the PRC, which could lead to a change in trade policy in the US. This would be a very negative development for Asia, which depends on trade and openness for its prosperity.

A weaker yuan would also reduce tourism demand across Asia. The large and growing number of tourists from the PRC is a major source of demand for many economies in the region. Reduced tourist traffic from the PRC resulting from a weaker yuan would be felt in the tourism sectors of many regional economies.

It is unlikely that the depreciation of the yuan would have a major effect on either foreign direct investment inflows or outflows in the absence of an extended and sharp depreciation since foreign direct investment is mainly driven by long-term fundamentals. However, since depreciation lowers the return on short-term portfolio investments, the PRC might experience short-term capital outflows, especially when the Federal Reserve accelerates the pace of its interest rate increases in 2017. Short-term capital outflows would further contribute to expectations of currency depreciation and may lead to more capital flight from the PRC. If such a negative feedback loop were to form, investor sentiment on the PRC would sour. Given the strong economic linkages between the PRC and many East and Southeast Asian economies, the expectations of further yuan depreciation would also lead to negative investor sentiment in the region and short-term capital outflows from Asia, including outflows from the region's bond markets. As an example of the impact of weakening investor sentiment in the region, in the third quarter of 2016, portfolio investment in Asian markets fell almost USD50 billion from the previous quarter. $^{a}$

In an unlikely case, an extended and sharp depreciation of the yuan also poses significant risk to the PRC's financial stability. The low interest rate environment globally during the past several years led to a build-up of foreign currency debt in the PRC, especially in the private sector (Figure B3.3). The yuan's rapid depreciation would increase the risk of currency mismatch in instances where US dollar loans were used to finance investments that generate revenues in yuan. This would also lead to the erosion of corporate profits. In addition, exacerbated capital outflows

\section{Figure B3.3: Foreign-Currency-Denominated Bonds Outstanding in the People's Republic of China}

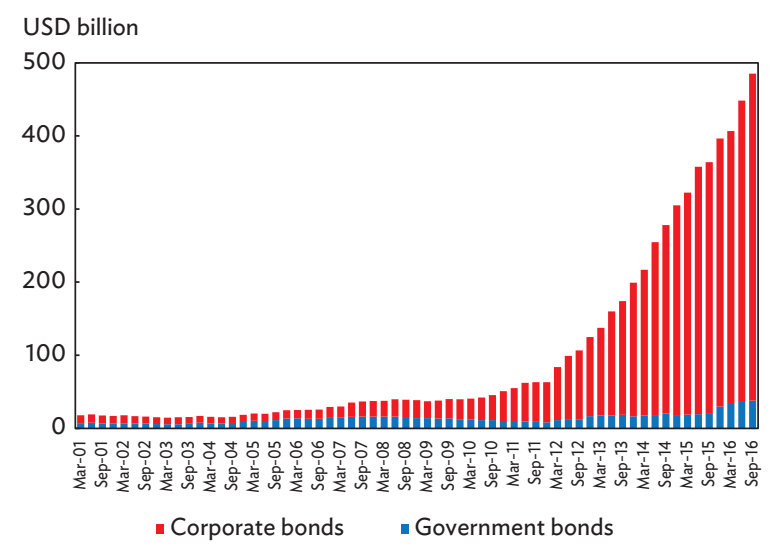

USD = United States dollar.

Source: AsianBondsOnline.

based on market expectations of further depreciation could trigger declines in asset prices, such as real estate, which would not only weaken the balance sheets of financial institutions but also heighten default risks for investors with significant leverage.

Despite the potential risks mentioned above, several factors are likely to mitigate the negative effects of a weaker yuan on Asia. First, the dominant driver of global currency markets at present is the prospect of a strong US dollar. The likely policy mix of the new US administrationfiscal stimulus and trade policy combined with monetary tightening-suggests that a strong US dollar will persist for some time. Given the dominance of the dollar in exchange rate movements, other Asian currencies are also likely to remain weak and the scope for their depreciation vis-à-vis the yuan will be limited.

Second, there are indications that PRC authorities view the yuan's rapid fall negatively given the risk it poses to financial stability. Throughout 2016, the People's Bank of China intervened in foreign exchange markets to prevent the rapid depreciation of the yuan by utilizing its foreign exchange reserves (Figure B3.4). Authorities may undertake an array of measures to arrest the yuan's slide, including tightening restrictions on capital outflows. While the yuan cannot be

\footnotetext{
a This figure was generated using data from Haver Analytics on 11 Asian economies: the People's Republic of China; Hong Kong, China; India; Indonesia; the Republic of Korea;
} Malaysia; the Philippines; Singapore; Taipei,China; Thailand; and Viet Nam. 


\section{Box 3: The Impact of the Chinese Yuan's Depreciation continued}

\section{Figure B3.4: Foreign Currency Reserves of the People's Republic of China}

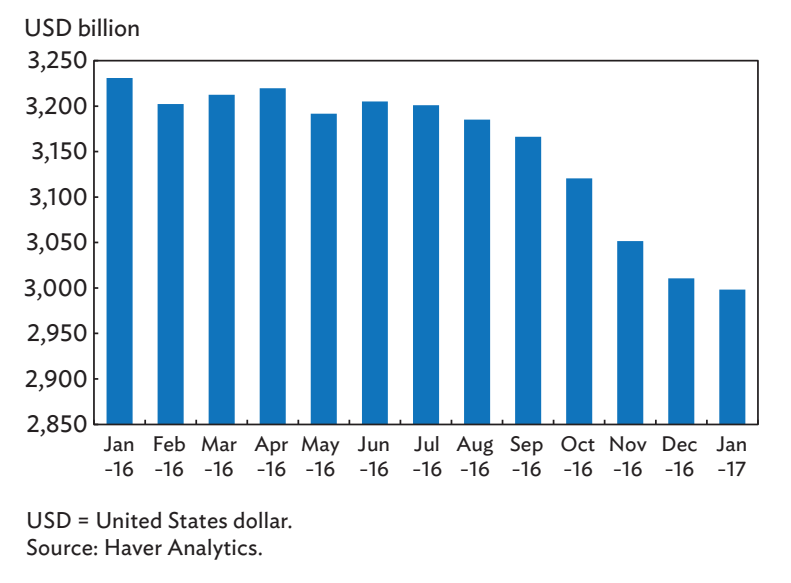

exchanged freely, every citizen of the PRC has an annual currency conversion quota of up to USD50,000. In practice, authorities may conduct tighter scrutiny of this conversion allowance by more closely examining the purpose of currency exchanges. Greater inspection of capital account trades, such as international foreign exchange transfers, could also be used to manage the pace of capital outflows. These potential measures imply that the central bank could put a hard floor on the yuan's decline. 


\section{Bond Market Developments in the Fourth Quarter of 2016}

\section{Size and Composition}

\section{Emerging East Asia's local currency bonds outstanding reached USD10.2 trillion at the end of December.}

The size of emerging East Asia's local currency (LCY) bond market climbed to USD10,177 billion at the end of December. ${ }^{8}$ Growth in the fourth quarter (Q4) of 2016 moderated to $2.4 \%$ quarter-on-quarter ( $\mathrm{q}-\mathrm{o}-\mathrm{q}$ ) from $3.3 \%$ $\mathrm{q}-\mathrm{o}-\mathrm{q}$ in the previous quarter (Figure 1a). Singapore and Thailand posted increased q-o-q growth rates in Q4 2016, while q-o-q growth slowed in the People's Republic of China (PRC); Hong Kong, China; Indonesia; and the Philippines. LCY bond markets in the Republic of Korea, Malaysia, and Viet Nam contracted on a q-o-q basis in Q4 2016.

\section{Figure 1a: Growth of Local Currency Bond Markets} in the Third and Fourth Quarters of 2016 (q-o-q, \%)

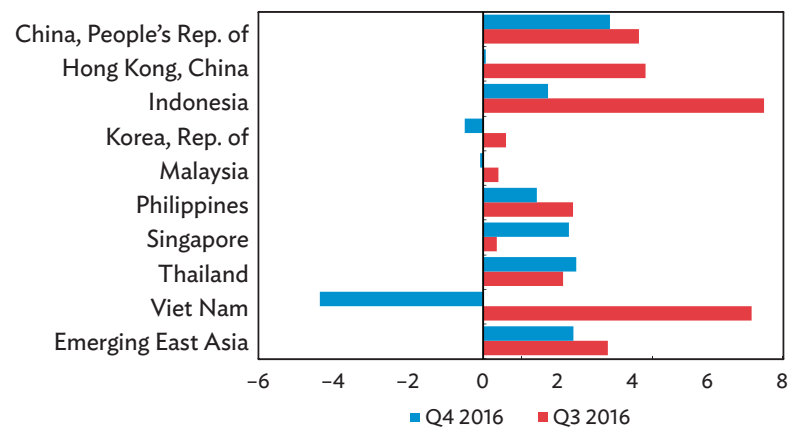

q-o-q = quarter-on-quarter, Q3 = third quarter, Q4 = fourth quarter.

Notes:

1. Calculated using data from national sources.

2. Growth rates are calculated from local currency base and do not include currency effects.

3. Emerging East Asia growth figures are based on 31 December 2016 currency exchange rates and do not include currency effects.

4. For Singapore, corporate bonds outstanding data based on AsianBondsOnline estimates.

Sources: People's Republic of China (ChinaBond and Wind Information); Hong Kong, China (Hong Kong Monetary Authority); Indonesia (Bank Indonesia; Directorate General of Budget Financing and Risk Management, Ministry of Finance; and Indonesia Stock Exchange); Republic of Korea (EDAILY BondWeb and the Bank of Korea); Malaysia (Bank Negara Malaysia); Philippines (Bureau of the Treasury and Bloomberg LP); Singapore (Monetary Authority of Singapore, Singapore Government Securities, and Bloomberg LP); Thailand (Bank of Thailand); and Viet Nam (Bloomberg LP and Vietnam Bond Market Association).
Leading the region in terms of LCY bond market size was the PRC, where outstanding bonds reached USD7,129 billion at the end of December, accounting for $70.0 \%$ of emerging East Asia's LCY bond market. The PRC's bond market expanded 3.4\% q-o-q in Q4 2016, compared with $4.2 \%$ q-o-q growth in the third quarter (Q3) of 2016, largely driven by increases in the stock of Treasury and other government bonds, particularly local government bonds. Policy bank bonds and corporate bonds also contributed to growth in the PRC bond market in Q4 2016.

The next largest LCY bond market in the region was the Republic of Korea's, with outstanding bonds of USD1,714 billion at the end of December. The LCY bond market in the Republic of Korea contracted on a q-o-q basis in Q4 2016, with both its government and corporate bond segments posting declines due to maturities exceeding new issuance. Government bonds slipped 1.0\% q-o-q in Q4 2016, largely driven by decreases in the stock of central bank bonds. The corporate bond market experienced a marginal drop of $0.2 \% \mathrm{q}-\mathrm{o}-\mathrm{q}$.

In Thailand, the LCY bond market expanded to reach a size of USD303 billion at the end of December on growth of $2.5 \% \mathrm{q}-\mathrm{o}-\mathrm{q}$, which stemmed largely from increases in the stock of central bank bonds and corporate bonds. In contrast, the stock of state-owned enterprise bonds contracted in Q4 2016, while government bonds and Treasury bills were broadly unchanged.

At the end of December, the outstanding size of Malaysia's LCY bond market stood at USD260 billion, contracting 0.1\% q-o-q in Q4 2016. The decline was largely driven by corporate bonds and central bank bills, which saw lower issuance volumes during the quarter. On the other hand, central government bonds posted a marginal $0.7 \%$ q-o-q hike, buoyed by an increase in the stock of Malaysian Government Securities.

Sukuk (Islamic bonds) comprise more than half of Malaysia's LCY bond market. At the end of December, Malaysia remained the largest Islamic debt market in

\footnotetext{
${ }^{8}$ Emerging East Asia comprises the People's Republic of China; Hong Kong, China; Indonesia; the Republic of Korea; Malaysia; the Philippines; Singapore; Thailand; and Viet Nam.
} 
emerging East Asia. About 41.7\% of total government bonds and $73.9 \%$ of total corporate bonds comprise sukuk.

Hong Kong, China's LCY bond market was broadly unchanged in Q4 2016 at a size of USD236 billion at the end of December. Government bonds declined as maturities exceeded new issuance of Exchange Fund Notes and Hong Kong Special Administrative Region bonds. The q-o-q growth in Hong Kong, China's LCY bond market was mostly led by corporate bonds as corporates locked in low borrowing costs. Increased demand for Hong Kong dollar-denominated assets as an investment option also encouraged corporates to borrow, following the depreciation of the Chinese yuan.

Singapore's LCY bond market climbed to a size of USD230 billion at the end of December, up 2.3\% q-o-q in Q4 2016. Growth was driven largely by the government bond segment on the back of increased sales of Monetary Authority of Singapore (MAS) bills and Singapore Government Securities bills and bonds during the quarter. In contrast, the corporate bond segment contracted 2.0\% q-o-q, with sentiments dampened by corporate defaults, particularly in the energy sector.

The LCY bond market in Indonesia rose to a size of USD163 billion at the end of December on 1.7\% q-o-q growth. Growth was largely driven by increases in the stock of central government bonds and corporate bonds. Modest growth in the stock of government bonds came about as the government has mostly fulfilled its issuance plan for the year, resulting in fewer auctions of Treasury instruments in Q4 2016. Corporate bonds climbed at a much faster pace, albeit from a lower base, on more active issuance by corporates as they took advantage of lower borrowing costs. Central bank bills, known as Sertifikat Bank Indonesia, declined as Bank Indonesia opted to use other tools to manage liquidity.

At the end of December, the Philippines' outstanding LCY bonds reached a size of USD98 billion, rising a modest 1.4\% q-o-q in Q4 2016. Growth was led by increases in the stock of Treasury bonds and corporate bonds. In contrast, the stocks of Treasury bills and other government bonds declined during the review period.

The size of the LCY bond market in Viet Nam slipped to USD44 billion at the end of December as growth contracted $4.4 \%$ q-o-q, led by a drop in government bonds, particularly State Bank of Vietnam bills and stateowned enterprise bonds. On the other hand, corporate bonds outstanding rose on new issuance by six corporate entities in Q4 2016.

Growth in emerging East Asia's LCY bond market also moderated on a year-on-year ( $y-0-y)$ basis in Q4 2016, rising at a slower pace of $16.4 \% \mathrm{y}-\mathrm{o}-\mathrm{y}$ compared with $19.4 \%$ y-o-y in the previous quarter (Figure 1b). While all markets posted positive $y-0-y$ growth during the review period, six out of the nine markets experienced slower rates of expansion. The exceptions to this trend were the Philippines and Singapore which both showed faster growth, and Thailand where growth was unchanged. The fastest-growing bond markets in Q4 2016 on a y-o-y basis were Indonesia (25.1\%); the PRC (22.0\%); and Hong Kong, China (13.4\%).

Emerging East Asia's LCY bond market continued to be dominated by government bonds, which comprised the equivalent of USD6,572 billion, or $64.6 \%$ of the regional total, at the end of December (Table 1). Growth moderated on both a q-o-q and y-o-y basis, easing to $3.2 \%$ q-o-q and $23.8 \%$ y-o-y from $4.8 \%$ q-o-q

\section{Figure 1b: Growth of Local Currency Bond Markets} in the Third and Fourth Quarters of 2016 (y-o-y, \%)

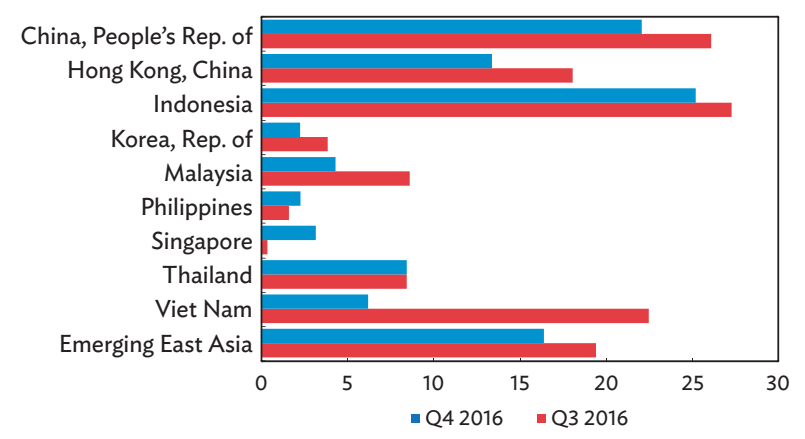

Q3 = third quarter, $Q 4$ = fourth quarter, $y-0-y=$ year-on-year.

Notes:

1. Calculated using data from national sources.

2. Growth rates are calculated from local currency base and do not include currency effects.

3. Emerging East Asia growth figures are based on 31 December 2016 currency exchange rates and do not include currency effects.

4. For Singapore, corporate bonds outstanding data based on AsianBondsOnline estimates.

Sources: People's Republic of China (ChinaBond and Wind Information); Hong Kong, China (Hong Kong Monetary Authority); Indonesia (Bank Indonesia; Directorate General of Budget Financing and Risk Management, Ministry of Finance; and Indonesia Stock Exchange); Republic of Korea (EDAILY BondWeb and the Bank of Korea); Malaysia (Bank Negara Malaysia); Philippines (Bureau of the Treasury and Bloomberg LP); Singapore (Monetary Authority of Singapore, Singapore Government Securities, and Bloomberg LP); Thailand (Bank of Thailand); and Viet Nam (Bloomberg LP and Vietnam Bond Market Association). 
Table 1: Size and Composition of Local Currency Bond Markets

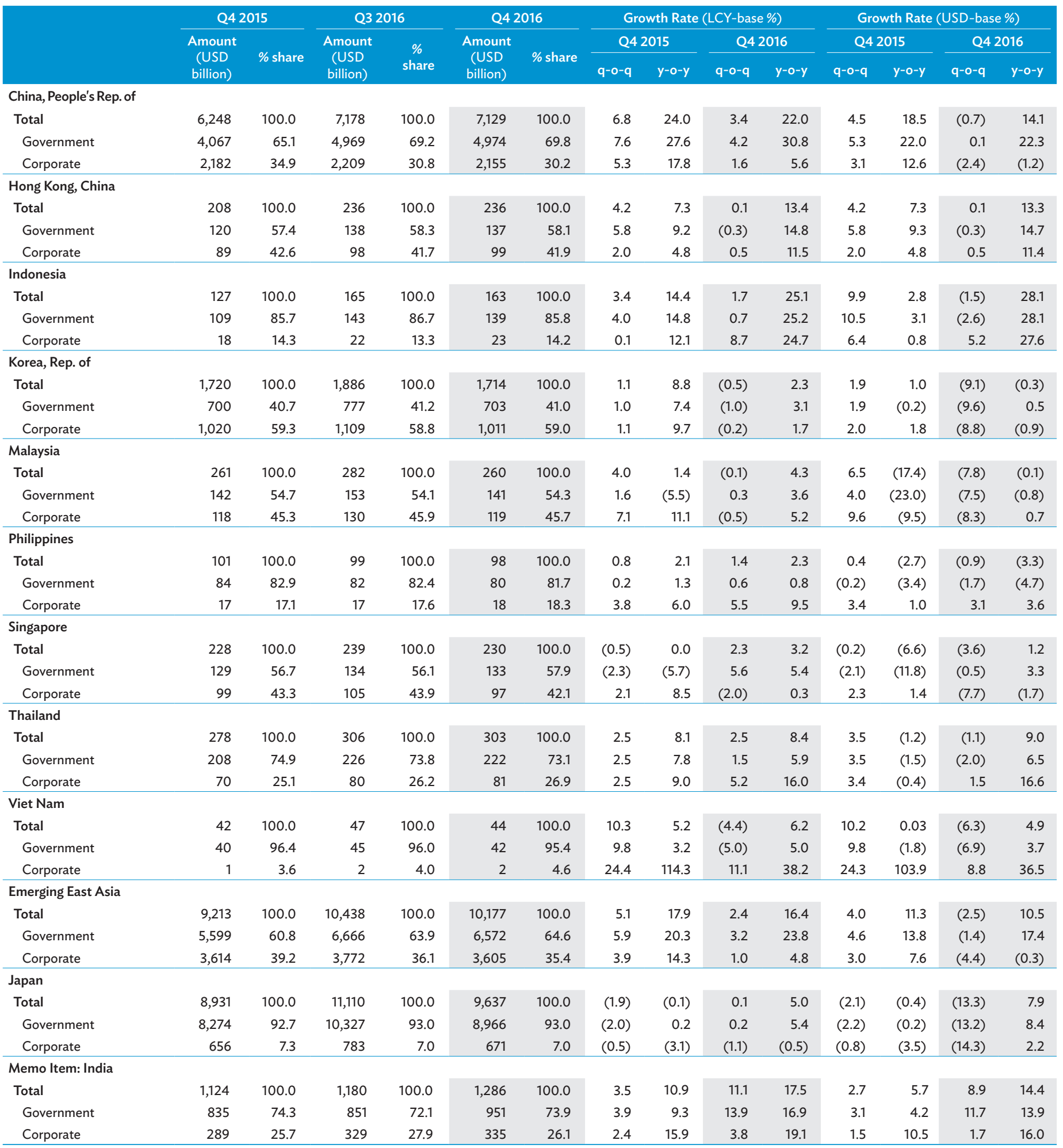

()$=$ negative, $L C Y=$ local currency, q-o-q = quarter-on-quarter, $Q 3=$ third quarter, $Q 4=$ fourth quarter, USD = United States dollar, $y-0-y=y e a r-o n-y e a r$.

Notes:

1. For Singapore, corporate bonds outstanding data based on AsianBonds Online estimates.

2. Corporate bonds include issues by financial institutions.

3. Bloomberg LP end-of-period LCY-USD rates are used.

4. For LCY base, emerging East Asia growth figures based on 31 December 2016 currency exchange rates and do not include currency effects.

5. Emerging East Asia comprises the People's Republic of China; Hong Kong, China; Indonesia; the Republic of Korea; Malaysia; the Philippines; Singapore; Thailand; and Viet Nam.

Sources: People's Republic of China (ChinaBond and Wind Information); Hong Kong, China (Hong Kong Monetary Authority); Indonesia (Bank Indonesia; Directorate General of Budget

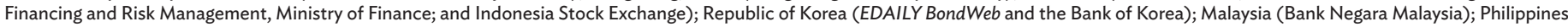

(Bureau of the Treasury and Bloomberg LP); Singapore (Monetary Authority of Singapore, Singapore Government Securities, and Bloomberg LP); Thailand (Bank of Thailand); Viet Nam

(Bloomberg LP and Vietnam Bond Market Association); Japan (Japan Securities Dealers Association); and India (Securities and Exchange Board of India and Bloomberg LP). 
and 27.0\% y-o-y in Q3 2016. The PRC led the region in terms of size, with government bonds outstanding of USD4,974 billion at the end of December. The Republic of Korea was second with outstanding bonds of USD703 billion and Thailand was next at USD222 billion. They were followed by Malaysia with government bonds valued at USD141 billion and Indonesia with USD139 billion. The government bond markets of Hong Kong, China and Singapore were the next largest, with outstanding bonds of USD137 billion and USD133 billion, respectively. The Philippines and Viet Nam have the two smallest government bond markets in emerging East Asia with government bonds outstanding of USD80 billion and USD42 billion, respectively.

LCY corporate bonds outstanding in emerging East Asia rose to USD3,605 billion at the end of December, reflecting gains of $1.0 \% \mathrm{q}-\mathrm{o}-\mathrm{q}$ and $4.8 \% \mathrm{y}-\mathrm{o}-\mathrm{y}$. The region's q-o-q growth rate in Q4 2016 was up from $0.7 \%$ q-o-q in Q3 2016 despite q-o-q contractions in the corporate bond markets of the Republic of Korea, Malaysia, and Singapore. All other emerging East Asian markets experienced positive q-o-q growth rates, which helped offset the decline. Higher growth in corporate bonds in Q4 2016 was due to increased issuance ahead of potential Federal Reserve rate increases in 2017.

The corporate bond segment's share of the region's overall LCY bond market stood at 35.4\% at the end of December. The PRC accounts for the lion's share of corporate bonds in emerging East Asia, comprising 59.8\% of the region's total outstanding stock of corporate bonds, followed by the Republic of Korea at $28.0 \%$.

As a share of GDP, emerging East Asia's LCY bond market was the equivalent of $68.5 \%$ at the end of December, down from $69.2 \%$ in the previous quarter (Table 2). The decline was due to much weaker growth in the corporate bond market. Corporate bonds as a share of GDP fell to 24.3\% in Q4 2016 from 25.0\% in Q3 2016, while the share of government bonds to GDP was broadly unchanged at $44.2 \%$. The Republic of Korea was a significant driver of the decline. Despite this, it maintained its position as the market with the largest share of bonds to GDP at $117.3 \%$ in Q4 2016, although this was down from $129.1 \%$ in the previous quarter, stemming from a decline in the share of corporate bond to GDP from 75.9\% in Q3 2016 to 69.2\% in Q4 2016. Malaysia's LCY bond market as a share of GDP was the second largest in the region at $94.9 \%$.
Table 2: Size and Composition of Local Currency Bond Markets (\% of GDP)

\begin{tabular}{|c|c|c|c|}
\hline & Q4 2015 & Q3 2016 & Q4 2016 \\
\hline \multicolumn{4}{|c|}{ China, People's Rep. of } \\
\hline Total & 58.9 & 66.0 & 66.5 \\
\hline Government & 38.3 & 45.7 & 46.4 \\
\hline Corporate & 20.6 & 20.3 & 20.1 \\
\hline \multicolumn{4}{|c|}{ Hong Kong, China } \\
\hline Total & 67.4 & 74.5 & 73.6 \\
\hline Government & 38.7 & 43.4 & 42.8 \\
\hline Corporate & 28.7 & 31.1 & 30.8 \\
\hline \multicolumn{4}{|l|}{ Indonesia } \\
\hline Total & 15.2 & 17.7 & 17.7 \\
\hline Government & 13.0 & 15.4 & 15.1 \\
\hline Corporate & 2.2 & 2.4 & 2.5 \\
\hline \multicolumn{4}{|l|}{ Korea, Rep. of } \\
\hline Total & 129.6 & 129.1 & 117.3 \\
\hline Government & 52.7 & 53.2 & 48.1 \\
\hline Corporate & 76.9 & 75.9 & 69.2 \\
\hline \multicolumn{4}{|l|}{ Malaysia } \\
\hline Total & 96.7 & 96.9 & 94.9 \\
\hline Government & 52.9 & 52.4 & 51.5 \\
\hline Corporate & 43.8 & 44.5 & 43.4 \\
\hline \multicolumn{4}{|l|}{ Philippines } \\
\hline Total & 35.8 & 34.0 & 33.7 \\
\hline Government & 29.7 & 28.0 & 27.5 \\
\hline Corporate & 6.1 & 6.0 & 6.2 \\
\hline \multicolumn{4}{|l|}{ Singapore } \\
\hline Total & 79.2 & 80.0 & 81.3 \\
\hline Government & 44.9 & 44.8 & 47.1 \\
\hline Corporate & 34.3 & 35.1 & 34.2 \\
\hline \multicolumn{4}{|l|}{ Thailand } \\
\hline Total & 73.2 & 74.7 & 75.6 \\
\hline Government & 54.8 & 55.1 & 55.3 \\
\hline Corporate & 18.4 & 19.6 & 20.3 \\
\hline \multicolumn{4}{|l|}{ Viet Nam } \\
\hline Total & 22.4 & 23.8 & 22.1 \\
\hline Government & 21.6 & 22.8 & 21.1 \\
\hline Corporate & 0.8 & 0.9 & 1.0 \\
\hline \multicolumn{4}{|c|}{ Emerging East Asia } \\
\hline Total & 63.6 & 69.2 & 68.5 \\
\hline Government & 38.6 & 44.2 & 44.2 \\
\hline Corporate & 24.9 & 25.0 & 24.3 \\
\hline \multicolumn{4}{|l|}{ Japan } \\
\hline Total & 202.4 & 210.4 & 209.8 \\
\hline Government & 187.5 & 195.6 & 195.2 \\
\hline Corporate & 14.9 & 14.8 & 14.6 \\
\hline
\end{tabular}

$\mathrm{GDP}=$ gross domestic product, $\mathrm{Q} 3$ = third quarter, $\mathrm{Q} 4$ = fourth quarter.

Notes:

1. Data for GDP is from CEIC. Q4 2016 GDP figure carried over from Q3 2016 for the Republic of Korea.

2. For Singapore, corporate bonds outstanding data based on AsianBondsOnline estimates.

Sources: People's Republic of China (ChinaBond and Wind Information); Hong Kong, China (Hong Kong Monetary Authority); Indonesia (Bank Indonesia; Directorate General of Budget Financing and Risk Management, Ministry of Finance; and Indonesia Stock Exchange); Republic of Korea (EDAILY BondWeb and the Bank of Korea); Malaysia (Bank Negara Malaysia); Philippines (Bureau of the Treasury and Bloomberg LP); Singapore (Monetary Authority of Singapore, Singapore Government Securities, and Bloomberg LP); Thailand (Bank of Thailand); Viet Nam (Bloomberg LP and Vietnam Bond Market Association); and Japan (Japan Securities Dealers Association). 
Foreign holding shares in emerging East Asian government bond markets fell amid volatile market conditions in Q4 2016.

The share of foreign holdings in most emerging East Asian markets declined in Q4 2016 due to a stronger US dollar and expectations of accelerated US interest rate hikes in 2017. At the end of December, nonresident holdings of LCY government bonds had declined on a q-o-q basis for most markets for which data are available (Figure 2). Recent data in January indicated a partial reversal, reflecting improving sentiments for emerging market assets.

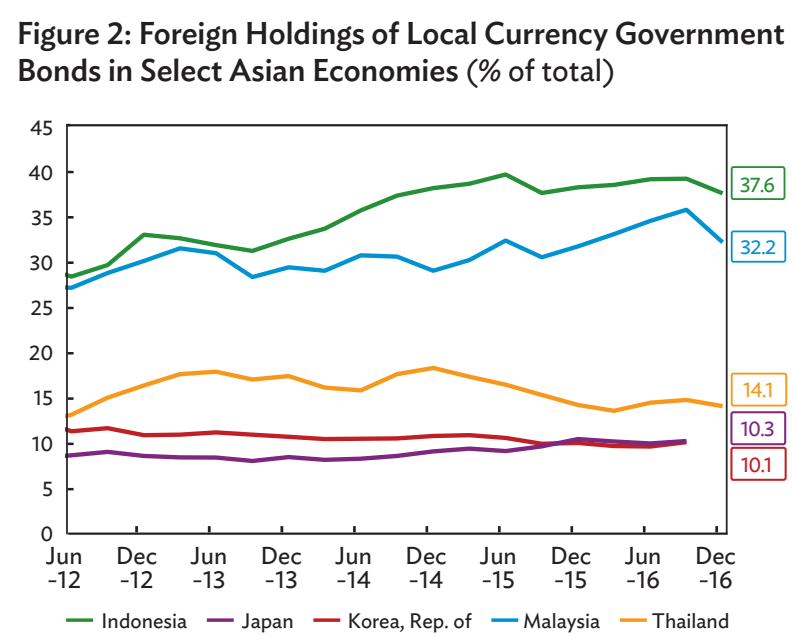

Note: Data as of end-December 2016 except for Japan and the Republic of Korea (end-September 2016).

Source: AsianBondsOnline.

At the end of December, the largest decline was noted in Malaysia, where foreign investors' holdings fell by more than 3 percentage points to $32.2 \%$. In the same period, the share of foreign holdings in Indonesia slipped by 1.6 percentage points to $37.6 \%$. In both Indonesia and Malaysia, a large share of government bonds is held by foreign investors, making these markets susceptible to capital flight during market sell-offs. This was evident in Q4 2016, when volatile financial market conditions persisted and the foreign holdings share in these two markets declined more rapidly than in regional markets with lower foreign holding shares.
At the same time, the Indonesian and Malaysian markets were not severely affected by these outflows as demand from domestic investors remained strong. Furthermore, market players have already priced in more aggressive rate hikes by the Federal Reserve in 2017 and the selloffs tend to be short-lived. In January, for example, foreign investors shored up their holdings of Indonesian government bonds with their share rising to $37.8 \%$ of the total.

Thailand's foreign holdings share slipped to $14.1 \%$ at the end of December from $14.8 \%$ at the end of September. In the Republic of Korea, the foreign holdings share inched up to $10.1 \%$ at the end of September from a share of $9.7 \%$ at the end of June.

For LCY corporate bonds, the negligible share of offshore investors is in stark contrast to foreign holdings of government bonds. In Indonesia, nonresident holdings accounted for only $6.4 \%$ of the total at the end of December, down slightly from $6.7 \%$ at the end of September (Figure 3). Since reaching a peak of 10.5\% at the end of March 2015, the foreign holdings share of the corporate bond market in Indonesia has steadily declined. The share of nonresident investor holdings in the Republic of Korea's LCY corporate bond market was a negligible $0.1 \%$ at the end of September.

Figure 3: Foreign Holdings of Local Currency Corporate Bonds in Indonesia and the Republic of Korea (\% of total)

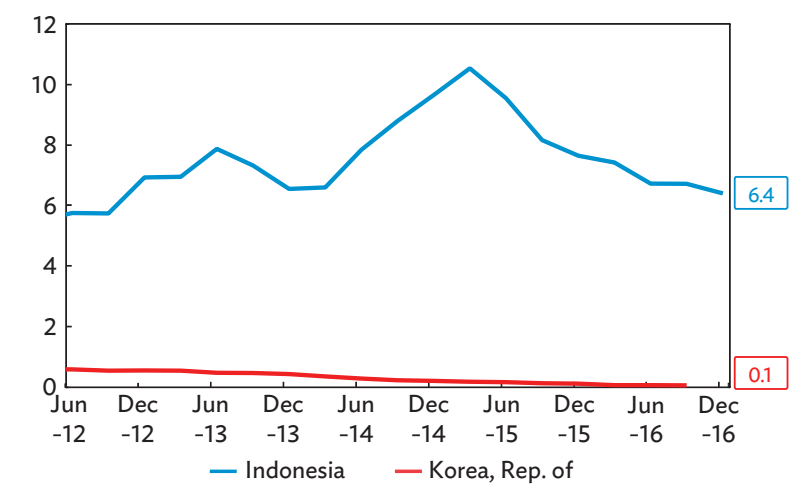

Notes:

1. For Indonesia, data as of end-December 2016.

2. For the Republic of Korea, data as of end-September 2016.

Sources: Based on data from Otoritas Jasa Keuangan and the Bank of Korea. 


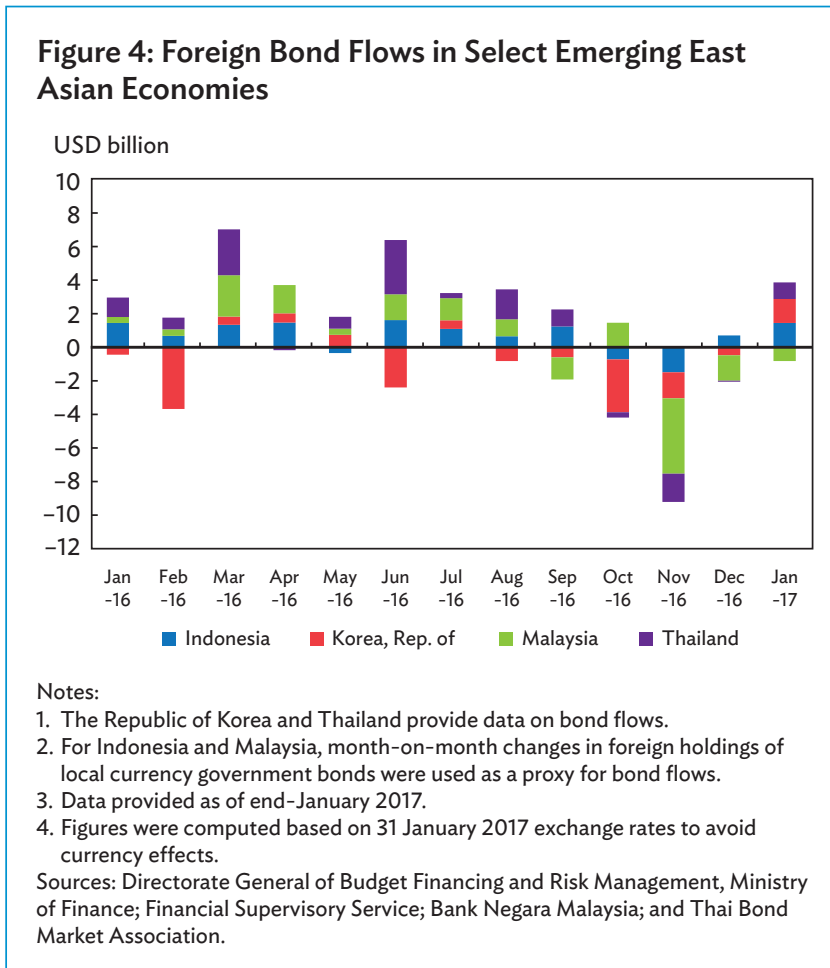

Foreign capital outflows from emerging East Asian bond markets were observed in Q4 2016.

As global financial markets were mostly volatile in Q4 2016, foreign investors became risk averse, which resulted in capital outflows in all four markets for which data on capital flows are available (Figure 4). Negative investor sentiments dragged down the region's bond markets on account of the uncertain direction of US economic policies and expectations of more frequent interest rate hikes by the Federal Reserve.

The largest bond outflows were noted in the Republic of Korea, where offshore investors reduced their bond holdings by USD5.1 billion in Q4 2016 following outflows of USD0.9 billion in Q3 2016. Data from the Financial Supervisory Service indicated that the outflows from the Republic of Korea's bond market were due largely to redemptions of maturing debt securities, particularly Korean Treasury Bonds and Monetary Stabilization Bonds (MSBs).

In Malaysia, capital outflows from the bond market totaled USD4.5 billion in Q4 2016, a reversal from inflows of USD1.0 billion in Q3 2016. Thailand posted net outflows of USD2.1 billion and Indonesia recorded bond outflows of USD1.4 billion.

For full-year 2016, the Republic of Korea's bond market was the only one in the region to post net foreign capital outflows at USD10.6 billion. Thailand had the largest foreign capital inflows in 2016, which amounted to USD9.4 billion. Indonesia and Malaysia also posted foreign capital inflows in 2016 at USD8.0 billion and USD3.3 billion, respectively.

More recent data suggest improved sentiments in the region's bond markets, with most experiencing a net inflow of foreign capital in January. Indonesia had the largest inflows in the region, with foreign investors adding USD1.5 billion to their holdings of IDR-denominated bonds. Rebounding strongly in January was the Republic of Korea, which after 5 months of posting capital outflows recorded net inflows of USD1.4 billion in January, due partly to a lower volume of bond redemptions. Thailand lodged net inflows of USD1.0 billion in its bond market in the first month of the year. The only exception to this trend among markets for which data are available was Malaysia, which continued to post capital outflows in January, albeit a much smaller USD0.8 billion. Malaysia posted outflows due to maturing bonds exceeding new issuances, leading to a smaller supply of available bonds to reinvest in.

Local currency bond issuance in emerging East Asia was down in the fourth quarter of 2016, driven by the decline in issuance of government bonds in most markets.

Issuance of LCY bonds in emerging East Asia was down 14.8\% q-o-q to USD946 billion in Q4 2016 (Table 3). The decline was driven by a $23.0 \%$ q-o-q contraction in the issuance of government bonds to USD608 billion, while corporate bond issuance rose $5.3 \%$ q-o-q to USD338 billion. Issuance in the region fell 8.4\% y-o-y on lower volumes of new issues in both the government and corporate bond markets.

Issuance of central government bonds-Treasury bills, Treasury bonds, and other government securitiesamounted to USD368 billion in Q4 2016, comprising $38.9 \%$ of total LCY bond issuance in the region. This was down 31.9\% from the volume issued in Q3 2016. Almost all markets in the region exhibited the same trend. The only exceptions were in Hong Kong, China and Singapore, 
Table 3: Local-Currency-Denominated Bond Issuance (gross)

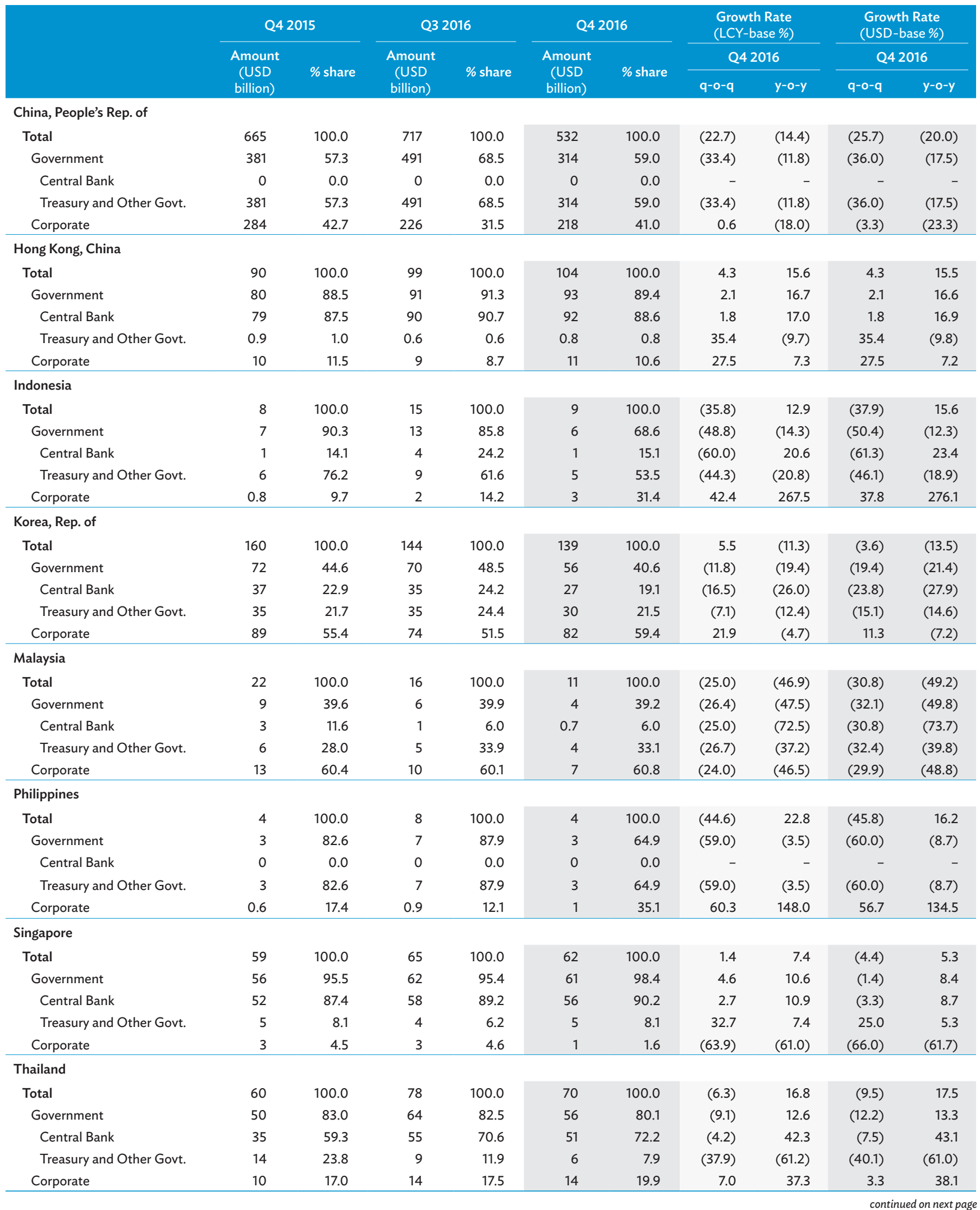


Table 3 continued

\begin{tabular}{|c|c|c|c|c|c|c|c|c|c|c|}
\hline & \multicolumn{2}{|c|}{ Q4 2015} & \multicolumn{2}{|c|}{ Q3 2016} & \multicolumn{2}{|c|}{ Q4 2016} & \multirow{2}{*}{\multicolumn{2}{|c|}{$\begin{array}{c}\begin{array}{c}\text { Growth Rate } \\
\text { (LCY-base \%) }\end{array} \\
\text { Q4 } 2016 \\
\end{array}$}} & \multirow{2}{*}{\multicolumn{2}{|c|}{$\begin{array}{c}\begin{array}{c}\text { Growth Rate } \\
\text { (USD-base \%) }\end{array} \\
\text { Q4 } 2016 \\
\end{array}$}} \\
\hline & \multirow{2}{*}{$\begin{array}{l}\text { Amount } \\
\text { (USD } \\
\text { billion) }\end{array}$} & \multirow{2}{*}{$\%$ share } & \multirow{2}{*}{$\begin{array}{l}\text { Amount } \\
\text { (USD } \\
\text { billion) }\end{array}$} & \multirow{2}{*}{$\%$ share } & \multirow{2}{*}{$\begin{array}{l}\text { Amount } \\
\text { (USD } \\
\text { billion) }\end{array}$} & \multirow{2}{*}{$\%$ share } & & & & \\
\hline & & & & & & & $q-o-q$ & $y-o-y$ & $q-0-q$ & $y-0-y$ \\
\hline \multicolumn{11}{|l|}{ Viet Nam } \\
\hline Total & 14 & 100.0 & 18 & 100.0 & 14 & 100.0 & $(22.1)$ & 2.5 & $(23.7)$ & 1.3 \\
\hline Government & 14 & 98.6 & 18 & 99.3 & 14 & 98.6 & $(22.7)$ & 2.5 & $(24.3)$ & 1.3 \\
\hline Central Bank & 7 & 52.7 & 15 & 83.3 & 13 & 90.1 & $(15.7)$ & 75.3 & $(17.4)$ & 73.2 \\
\hline Treasury and Other Govt. & 6 & 45.9 & 3 & 16.0 & 1 & 8.4 & $(59.0)$ & $(81.1)$ & $(59.8)$ & $(81.4)$ \\
\hline Corporate & 0.2 & 1.4 & 0.1 & 0.7 & 0.2 & 1.4 & 69.7 & 3.4 & 66.2 & 2.2 \\
\hline \multicolumn{11}{|l|}{ Emerging East Asia } \\
\hline Total & 1,082 & 100.0 & 1,160 & 100.0 & 946 & 100.0 & $(14.8)$ & (8.4) & $(18.5)$ & $(12.6)$ \\
\hline Government & 671 & 62.0 & 822 & 70.9 & 608 & 64.3 & $(23.0)$ & $(5.4)$ & $(26.0)$ & (9.4) \\
\hline Central Bank & 213 & 19.7 & 258 & 22.2 & 240 & 25.4 & (3.6) & 13.5 & (6.9) & 12.4 \\
\hline Treasury and Other Govt. & 457 & 42.3 & 564 & 48.7 & 368 & 38.9 & $(31.9)$ & $(14.7)$ & $(34.8)$ & (19.6) \\
\hline Corporate & 411 & 38.0 & 338 & 29.1 & 338 & 35.7 & 5.3 & $(13.3)$ & 0.1 & (17.8) \\
\hline \multicolumn{11}{|l|}{ Japan } \\
\hline Total & 434 & 100.0 & 509 & 100.0 & 413 & 100.0 & $(6.2)$ & $(7.3)$ & $(18.7)$ & (4.7) \\
\hline Government & 410 & 94.7 & 454 & 89.3 & 389 & 94.1 & $(1.1)$ & (7.8) & $(14.3)$ & (5.2) \\
\hline Central Bank & 0 & 0.0 & 0 & 0.0 & 0 & 0.0 & - & - & - & - \\
\hline Treasury and Other Govt. & 410 & 94.7 & 454 & 89.3 & 389 & 94.1 & (1.1) & (7.8) & $(14.3)$ & (5.2) \\
\hline Corporate & 23 & 5.3 & 55 & 10.7 & 24 & 5.9 & $(48.7)$ & 1.6 & $(55.6)$ & 4.4 \\
\hline
\end{tabular}

()$=$ negative, - = not applicable, $L C Y=$ local currency, $q-o-q=$ quarter-on-quarter, $Q 3=$ third quarter, $Q 4=$ fourth quarter, USD = United States dollar, $y-0-y=$ year-on-year. Notes:

1. Corporate bonds include issues by financial institutions.

2. Bloomberg LP end-of-period LCY-USD rates are used.

3. For LCY-base, emerging East Asia growth figures are based on 31 December 2016 currency exchange rates and do not include currency effects.

Sources: People's Republic of China (ChinaBond); Hong Kong, China (Hong Kong Monetary Authority); Indonesia (Bank Indonesia; Directorate General of Budget Financing and Risk Management, Ministry of Finance; and Indonesia Stock Exchange); Republic of Korea (EDAILY Bondweb and the Bank of Korea); Malaysia (Bank Negara Malaysia); Philippines (Bloomberg LP and Bureau of the Treasury); Singapore (Singapore Government Securities and Bloomberg LP); Thailand (Bank of Thailand and Thailand Bond Market Association); Viet Nam (Bloomberg LP and Vietnam Bond Market Association); and Japan (Japan Securities Dealers Association).

which issue central government bonds to provide yield curve guidance for the pricing of private debt securities, unlike other governments in the region that issue bonds to fund budget deficits. The q-o-q increases in issuances in Hong Kong, China and Singapore were part of their programmed issuance plans for the year.

The main driver of the $\mathrm{q}-\mathrm{O}-\mathrm{q}$ contraction in central government bonds was the $33.4 \%$ q-o-q decline in issuance by the PRC. The PRC accounts for $85.4 \%$ of the region's total issuance of central government paper. The slowdown was most evident in the issuance of local government bonds, which fell to CNY959 billion in Q4 2016 from CNY1,508 billion in Q3 2016. This was partly due to the implementation of a quota by the Ministry of Finance in bond swaps of local government bank loans into bonds, which is part of efforts to restructure local government debt. The auctions of Treasury bonds, particularly during the latter part of the year, was met with low demand mostly due to tight domestic liquidity conditions and the expected
Federal Reserve rate hikes. Issuance of policy bank bonds also fell in Q4 2016.

Issuance of central bank bonds, which account for $25.4 \%$ of the region's issuance total, also declined in Q4 2016, albeit at a slower pace of 3.6\% q-o-q, to USD240 billion. Most central banks in the region issued fewer bonds in Q4 2016 as liquidity conditions were tight. The largest drop in volume was in the issuance of MSBs by the Bank of Korea, which reduced its planned auctions to help stabilize the market after the US elections. The decline in volume was capped by the relatively stable issuance of the two largest issuers of central bank bonds in emerging East Asia, the Hong Kong Monetary Authority and MAS, which together account for $61.7 \%$ of the region's total.

In contrast, corporate bond issuance in emerging East Asia rose 5.3\% q-o-q to reach USD338 billion in Q4 2016, driven by the $21.9 \%$ q-o-q surge in new corporate bond issues in the Republic of Korea, the 
second largest corporate bond issuer in the region. Its corporate bond market accounted for nearly one fourth of the region's corporate issuance total. Most markets in the region posted double-digit q-o-q growth in Q4 2016.

The PRC corporate bond market, which accounted for nearly two thirds of new corporate bond issuance in the region, posted marginal growth of $0.6 \%$ q-o-q. Malaysia and Singapore posted q-o-q contractions of $24.0 \%$ and 63.9\%, respectively, in Q4 2016. The tepid issuance in Singapore was partly due to bond defaults in the second half of the year leading to risk aversion in the corporate bond sector.

Most markets in the region issued lower volumes of LCY bonds in Q4 2016 compared with the previous quarter. The exceptions were Hong Kong, China; the Republic of Korea; and Singapore.

The PRC remained the largest issuer of LCY bonds in Q4 2016 with total issuance of USD532 billion, comprising $56.3 \%$ of the regional total. Issuance for the quarter fell $22.7 \%$ q-o-q and $14.4 \%$ y-o-y. The q-o-q contraction was mainly due to lower issuance volumes for government bonds while new corporate bond issues were almost unchanged from the previous quarter. The tepid issuance of corporate bonds in Q4 2016 was a result of some companies canceling or postponing planned bond sales due to market volatility and liquidity concerns. The $y-0-y$ decline was driven by falling issuance of both government and corporate bonds.

The Republic of Korea was the second largest issuer in Q4 2016 with total issuances up 5.5\% q-o-q to USD139 billion. The rise in corporate bond issuance was capped by a decline in issuance of government securities. The government and the Bank of Korea decreased issuance of Korea Treasury Bonds and MSBs, respectively, to help stabilize market volatility after the US elections in November. On a y-o-y basis, total issuance fell 11.3\%, with declines in both the government and corporate bond sectors.

In Hong Kong, China, total LCY bond issuance rose 4.3\% q-o-q to USD104 billion. The Hong Kong Monetary Authority issued more Exchange Fund Bills in Q4 2016 in response to increased demand from banks amid rising liquidity in the market. Corporate bond issuance was also up in Q4 2016 as companies took advantage of relatively lower interest rates. Compared to a year earlier, growth in LCY bond issuance in Hong Kong, China accelerated to $15.6 \%$ y-o-y.

Singapore's LCY bond issuance of USD62 billion in Q4 2016 was almost at par with that of Q3 2016, inching up $1.4 \% \mathrm{q}-\mathrm{o}-\mathrm{q}$, as the rise in issuance of government bonds was capped by lower issuance of corporate bonds. On a y-o-y basis, issuance in Singapore rose 7.4\%, led by MAS bills, which are used to mop up excess liquidity and manage currency volatility.

Bond issuance in Thailand amounted to USD70 billion, down $6.3 \%$ q-o-q on fewer planned auctions of central government paper and Bank of Thailand bonds. In addition, a number of the auctions were only partially awarded and met with weak demand as Q4 2016 saw the lowest average bid coverage ratios for auctions of government and central bank bonds. Meanwhile, issuance of corporate bonds rose $7.0 \%$ q-o-q. On a y-o-y basis, Thailand's bond issuance rose $16.8 \%$, as both the government and corporate bond segments posted growth.

In Viet Nam, LCY bond issuance dropped 22.1\% q-o-q to USD14 billion due to reduced issuance by the central government and the State Bank of Vietnam. The corporate bond sector recorded a surge in issuance in Q4 2016 that was driven by two firms. Compared to the same period a year earlier, issuance in Viet Nam inched up $2.5 \%$.

Malaysia's LCY bond issuance in Q4 2016 was down $25.0 \%$ q-o-q to USD11 billion as both government and corporate bond issuance fell. Issuance of central government bonds dropped partly due to a smaller budget deficit target as part of Malaysia's fiscal consolidation efforts. Total issuance in Malaysia's LCY bond market fell $46.9 \% \mathrm{y}-\mathrm{o}-\mathrm{y}$ on declines in both sectors.

In Indonesia, total LCY bond issuance fell $35.8 \%$ q-o-q to USD9 billion, largely driven by fewer scheduled auctions of central government bonds in Q4 2016 as the government had mostly met its program goals for the year through a frontloading policy in which it issues more bonds during the first half of the year. Issuance of central bank bonds also declined in Q4 2016 as Bank Indonesia continued to use other monetary policy tools to manage liquidity. Meanwhile, new corporate bond issues surged 42.4\% q-o-q in Q4 2016 as corporates took advantage of lower borrowing costs. On a y-o-y basis, Indonesia's bond 
issuance rose $12.9 \%$, driven by a jump in new corporate bond issues.

Total LCY bond issuance dropped the most in the Philippines, declining 44.6\% q-o-q to USD4 billion. This was partly the result of a high base in Q3 2016 when the Government of the Philippines issued PHP100 billion worth of retail Treasury bonds. The Bureau of the Treasury also rejected or only partially awarded most of its scheduled auctions of Treasury bills and bonds in Q4 2016 as market participants sought higher yields given uncertainty in the market. Bonds issued by Philippine corporates rose 60.3\% q-o-q in Q4 2016 as they opted to increase borrowing in anticipation of higher interest rates. Total issuance rose $22.8 \%$ y-o-y, driven mainly by growth in the corporate bond sector.

Total cross-border bond issuance in emerging East Asia amounted to USD2.2 billion, reflecting contractions of 37.5\% q-o-q and 12.5\% y-o-y in Q4 2016.

Three PRC-based financial firms sold HKD864 million (USD111 million) worth of bonds denominated in Hong Kong dollars in Q4 2016, while five institutions from Hong Kong, China issued a combined CNY7.5 billion of yuan-denominated bonds with tenors of between 3 months and 5 years.

Issuers from the Republic of Korea sold Hong Kong dollar debt securities worth HKD1.6 billion and yuandenominated bonds amounting to CNY1 billion. Stateowned Korea Development Bank was the largest crossborder issuer, with issuance in both Hong Kong dollars and Chinese yuan.

The Lao People's Democratic Republic (Lao PDR) issued a multi-tranche sovereign bond amounting to THB11 billion. The longest tenor was 12 years with a coupon rate of $5.15 \%$. It was the fifth issuance in Thai baht by the Government of the Lao PDR since it first began such issuances in May 2013.

Malaysia's KNM Group, a metal processing and fabrication company, raised THB2.78 billion worth of 5 -year bonds at a 3.0\% coupon, while Maybank issued HKD378 million worth of 5-year bonds with a 2.05\% coupon.
In Singapore, new cross-border bonds were mainly issued by two financial institutions in Q4 2016. Standard Chartered Bank sold a multi-tranche bond comprising yuan-denominated (CNY554 million) and rupiahdenominated (IDR386 billion) tranches. Nomura International Funding held a dual-tranche sale of KRW120 billion worth of bonds with a 15-year maturity.

Total G3 currency bond issuance in emerging East Asia climbed to USD216 billion in 2016.

G3 currency bond issuance in emerging East Asia in Q4 2016 amounted to USD62.6 billion, up 14.7\% q-o-q and $25.0 \% \mathrm{y}-0-\mathrm{y} .{ }^{9}$ Bond sales denominated in $\mathrm{G} 3$ currencies in 2016 reached USD216 billion, topping the USD183 billion recorded in 2015 (Table 4).

US dollar-denominated bonds continued to account for the largest share in emerging East Asia's G3 currency bond market, comprising $90.1 \%$ of the total issuance in 2016. Bond sales increased 17.3\% y-o-y to USD194.3 billion from USD165.6 billion in 2015. The issuance of eurodenominated bonds, which comprised $8.6 \%$ of total G3 issuance, rose 30\% y-o-y to USD18.4 billion. Japanese yen bond issuance, which made up 1.3\% of the total, increased $1.9 \%$ y-o-y to USD2.9 billion.

The larger G3 currency bond sales in 2016, particularly in Q4 2016, were mainly due to issuers taking advantage of low funding costs ahead of the Federal Reserve talking a more aggressive monetary policy stance in 2017. The PRC had the highest G3 currency bond sales in 2016 and in Viet Nam there was no G3 issuance during the year. All other markets in the region registered increased G3 currency bond issuance in 2016 compared to a year earlier, except for Malaysia and the Philippines.

Despite the slowdown in the PRC's economy in 2016, it continued to fuel the growth of the region's G3 currency bond market. The PRC issued a total of USD120 billion in 2016, an increase of $15.9 \%$ over the amount issued in 2015. The PRC accounted for more than half of the total G3 currency bond issuance in the region in 2016 and about $92 \%$ of this issuance was denominated in US dollars. Firms in the PRC took advantage of low funding costs for US dollar debt to pay off maturing

\footnotetext{
${ }^{9} \mathrm{G} 3$ currency bonds are bonds denominated in either euros, Japanese yen, or US dollars.
} 
Table 4: G3 Currency Bond Issuance

\begin{tabular}{|c|c|c|c|c|c|}
\hline \multicolumn{3}{|l|}{2015} & \multicolumn{3}{|l|}{2016} \\
\hline Issuer & $\begin{array}{c}\text { Amount } \\
\text { (USD million) }\end{array}$ & Issue Date & Issuer & $\begin{array}{c}\text { Amount } \\
\text { (USD million) }\end{array}$ & Issue Date \\
\hline China, People's Rep. of & 103,527 & & China, People's Rep. of & 120,019 & \\
\hline China Construction Bank 4.65\% Perpetual & 3,050 & 16-Dec-15 & China Cinda Asset Management 4.45\% Perpetual & 3,200 & 30-Sep-16 \\
\hline Sinopec $2.5 \% 2020$ & 2,500 & 28-Apr-15 & Proven Honour Capital 4.125\% 2026 & 2,000 & 6-May-16 \\
\hline Bank of Communications 5\% Perpetual & 2,450 & 29-Jul-15 & China Minsheng Banking 4.95\% Perpetual & 1,439 & 14-Dec-16 \\
\hline China Construction Bank 3.875\% 2025 & 2,000 & 13-May-15 & Huarong Finance 3.625\% 2021 & 1,350 & 22-Nov-16 \\
\hline CNOOC Finance 3.5\% 2025 & 2,000 & 5-May-15 & Sinopec 2\% 2021 & 1,300 & 29-Sep-16 \\
\hline ICBC $4.875 \% 2025$ & 2,000 & 21-Sep-15 & Export-Import Bank of China 2\% 2021 & 1,250 & 26-Apr-16 \\
\hline China Cinda Finance (2015) 4.25\% 2025 & 1,700 & 23-Apr-15 & Export-Import Bank of China 0.25\% 2019 & 1,209 & 2-Dec-16 \\
\hline Evergrande Real Estate Group 9\% Perpetual & 1,500 & 29-Dec-15 & Sinopec $1.75 \% 2019$ & 1,100 & 29-Sep-16 \\
\hline Others & 86,327 & & Others & 107,171 & \\
\hline Hong Kong, China & 18,702 & & Hong Kong, China & 29,204 & \\
\hline Shimao Property 8.375\% 2022 & 1,100 & $10-$ Feb-15 & China Overseas Finance 0\% 2023 & 1,500 & 5-Jan-16 \\
\hline Hong Kong, China (Sovereign) Sukuk 1.894\% 2020 & 1,000 & 3-Jun-15 & CK Hutchison $1.25 \% 2023$ & 1,420 & 8-Apr-16 \\
\hline Others & 16,602 & & Others & 26,284 & \\
\hline Indonesia & 15,572 & & Indonesia & 17,888 & \\
\hline Indonesia (Sovereign) 4.75\% 2026 & 2,250 & 8-Dec-15 & Perusahaan Penerbit SBSN Sukuk 4.55\% 2026 & 1,750 & 29-Mar-16 \\
\hline Indonesia (Sovereign) 4.125\% 2025 & 2,000 & 15-Jan-15 & Indonesia (Sovereign) 2.625\% 2023 & 1,578 & 14-Jun-16 \\
\hline Indonesia (Sovereign) 5.125\% 2045 & 2,000 & $15-J a n-15$ & Indonesia (Sovereign) 3.75\% 2028 & 1,578 & 14-Jun-16 \\
\hline Perusahaan Penerbit SBSN Sukuk 4.325\% 2025 & 2,000 & 28-May-15 & Indonesia (Sovereign) 5.25\% 2047 & 1,500 & 8-Dec-16 \\
\hline Indonesia (Sovereign) 3.375\% 2025 & 1,397 & $30-J u l-15$ & Indonesia (Sovereign) 4.352027 & 1,250 & 8-Dec-16 \\
\hline Others & 5,925 & & Others & 10,233 & \\
\hline Korea, Rep. of & 23,348 & & Korea, Rep. of & 28,593 & \\
\hline Korea Eximbank 2.875\% 2025 & 1,250 & 21-Jan-15 & Korea Development Bank 3\% 2026 & 1,000 & 13-Jan-16 \\
\hline Korea Eximbank 2.25\% 2020 & 1,000 & 21-Jan-15 & Korea Eximbank 1.75\% 2019 & 1,000 & 26-May-16 \\
\hline Korea Eximbank 3.25\% 2025 & 1,000 & 10-Nov-15 & Korea Eximbank 2.625\% 2026 & 1,000 & 26-May-16 \\
\hline Others & 20,098 & & Others & 25,593 & \\
\hline Lao People's Dem. Rep. & 182 & & Lao People's Dem. Rep. & 312 & \\
\hline Malaysia & 8,496 & & Malaysia & 6,026 & \\
\hline Petronas Capital 3.5\% 2025 & 1,500 & 18-Mar-15 & Malaysia (Sovereign) Sukuk 3.179\% 2026 & 1,000 & 27-Apr-16 \\
\hline Petronas Capital 4.5\% 2045 & 1,500 & 18-Mar-15 & Danga Capital 3.035\% 2021 & 750 & 1-Mar-16 \\
\hline Petronas Global Sukuk 2.707\% 2020 & 1,250 & 18-Mar-15 & TNB Global Ventures Capital 3.244\% 2026 & 750 & 19-Oct-16 \\
\hline Others & 4,246 & & Others & 3,526 & \\
\hline Philippines & 4,256 & & Philippines & 2,675 & \\
\hline Philippines (Sovereign) 3.95\% 2040 & 2,000 & 20-Jan-15 & Philippines (Sovereign) 3.7\% 2041 & 2,000 & 1-Mar-16 \\
\hline Royal Capital BV 5.5\% Perpetual & 450 & 26-Aug-15 & Others & 675 & \\
\hline Others & 1,806 & & Singapore & 9,636 & \\
\hline Singapore & 8,346 & & BOC Aviation 3.875\% 2026 & 750 & 27-Apr-16 \\
\hline Global Logistics Properties 3.875\% 2025 & 1,000 & 4-Jun-15 & DBS Group 3.6\% Perpetual & 750 & 7-Sep-16 \\
\hline DBS Bank 1.625\% 2018 & 1,000 & 6-Aug-15 & Others & 8,136 & \\
\hline BOC Aviation 3\% 2020 & 750 & 30-Mar-15 & Thailand & 1,225 & \\
\hline Others & 5,596 & & Kasikorn Bank PLC 2.375\% 2022 & 400 & $6-O c t-16$ \\
\hline Thailand & 176 & & Others & 825 & \\
\hline Emerging East Asia Total & 182,605 & & Emerging East Asia Total & 215,579 & \\
\hline Memo Items: & & & Memo Items: & & \\
\hline India & 10,919 & & India & 8,354 & \\
\hline Bharti Airtel 4.375\% 2025 & 1,000 & 10-Jun-15 & Export-Import Bank of India 3.375\% 2026 & 1,000 & 5-Aug-16 \\
\hline Others & 9,919 & & Others & 7,354 & \\
\hline Sri Lanka & 3,649 & & Sri Lanka & 2,916 & \\
\hline
\end{tabular}

USD = United States dollar.

Notes:

1. Emerging East Asia comprises the People's Republic of China; Hong Kong, China; Indonesia; the Republic of Korea; the Lao People's Democratic Republic; Malaysia; the Philippines; Singapore; Thailand; and Viet Nam.

2. Data exclude certificates of deposit.

3. G3 currency bonds are bonds denominated in either euros, Japanese yen, or US dollars.

Source: AsianBondsOnline calculations based on Bloomberg LP data. 
debt or refinance existing debt. There was also an implicit tightening in the PRC's domestic credit, thus prompting companies to tap the US dollar bond market. China Development Bank was the PRC's largest issuer of $\mathrm{G} 3$ currency bonds in 2016, raising more than USD6.3 billion from the combined sale of euro- and US dollar-denominated bonds.

Hong Kong, China overtook the Republic of Korea as the second largest G3 currency bond issuer in emerging East Asia in 2016 with total issuance of USD29.2 billion, up 56.2\% from the preceding year. Most G3 currency bond issuance in Hong Kong, China came from the financial sector. The full-year 2016 amount was shored up by issuances during Q4 2016, which saw the highest quarterly bond sales of the year at USD11.7 billion, a 66.3\% q-o-q increase from Q3 2016. China Great Wall International Holdings was the largest bond issuer in Q4 2016 with a total of USD1.5 billion comprising a USD800 million 5-year bond with a $2.625 \%$ coupon and a USD700 million 3-year bond with a $2.25 \%$ coupon.

The Republic of Korea's G3 currency bond issuance increased 22.5\% y-o-y to USD28.6 billion in 2016. In Q4 2016, the Republic of Korea's G3 bond issuance reached USD7.7 billion with the government-owned Korea Export-Import Bank selling a total of USD3.1 billion.

Markets in the Association of Southeast Asian Nations (ASEAN) saw total sales of G3 currency bonds increase slightly in 2016 to USD37.8 billion from USD37.0 billion in 2015. Indonesia continued to lead all ASEAN economies, accounting for almost half of its aggregate $\mathrm{G} 3$ bond issuance. Indonesia's new $\mathrm{G} 3$ issuances in 2016 increased $14.9 \%$ y-o-y to USD17.9 billion while a total of USD5.6 billion was issued in Q4 2016. Among this quarterly total, Indonesia issued a triple-tranche sovereign bond-consisting of USD1.5 billion of 30-year bonds, USD1.25 billon of 10-year bonds, and USD750 million of 5-year bonds - to prefund its 2017 state budget.

Singapore issued USD9.6 billion of G3 currency bonds in 2016 on growth of 15.5\% y-o-y. In Q4 2016, the economy's $\mathrm{G} 3$ bond issuance dropped $66.3 \%$ q-o-q, which was reflective of a traditionally slow period. A large part of the Q4 2016 issuance came from SingTel Group Treasury, which sold USD500 million worth of bonds. In Thailand, USD1.2 billion worth of G3 currency bonds were sold in 2016 and USD550 million in Q4 2016.
The Lao PDR had no G3 bond sales in Q4 2016; all of its issuance during the year took place in Q3 2016.

The Philippines' G3 currency bond sales declined $37.1 \%$ y-o-y to USD2.7 billion in 2016, with the remaining sales during the year coming in Q4 2016 following the USD2.0 billion sovereign bond issuance in the first quarter. Sales in Q4 2016 came from corporate entities issuing a total of USD675 million. In Malaysia, G3 currency bond issuance was down to USD6.0 billion on a $29.0 \%$ y-o-y drop. The decline was contributed to by the low issuance volume in Q3 2016, but the recent recovery in oil prices and the stabilization of the Malaysian ringgit is helping to dispel negative investor sentiment.

On a monthly basis, the lowest volumes of G3 currency bond issuance in emerging East Asian economies were registered in February and August at USD6.9 billion and USD9.5 billion, respectively (Figure 5). The decline in August was followed by a sharp rise in issuance in September to USD25.2 billion. Succeeding months saw a gradual fall in $\mathrm{G} 3$ currency bond issuance, although the monthly amounts remained above the 2016 monthly average bond sales of USD17.9 billion. This trend may have been the result of issuers taking advantage of low borrowing costs ahead of the accelerated pace of rate hikes by the Federal Reserve in 2017.

\section{Figure 5: G3 Currency Bond Issuance in Emerging East Asia}

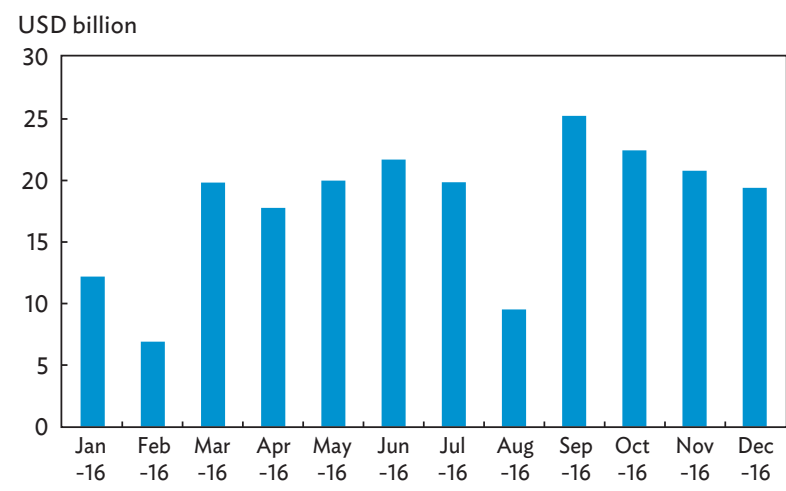

USD = United States dollar.

Notes:

1. Emerging East Asia comprises the People's Republic of China; Hong Kong, China; Indonesia; the Republic of Korea; the Lao People's Democratic Republic; Malaysia; the Philippines; Singapore; Thailand; and Viet Nam.

2. G3 currency bonds are bonds denominated in either euros, Japanese yen, or US dollars.

3. Figures were computed based on 31 December 2016 currency exchange rates and do not include currency effects.

Source: AsianBondsOnline calculations based on Bloomberg LP data. 
Government bond yield curves in most emerging East Asian markets fell for most tenors on improving investor sentiment.

Markets in emerging East Asia are experiencing renewed optimism as there are signs that global economic growth is gaining momentum, leading to increased risk appetite in a number of emerging East Asian economies.

In the US, due to the trend of economic growth in the latter half of 2016 and in the early months of 2017, the Federal Reserve has hinted that it would accelerate the pace of its rate hikes in 2017. Job gains averaged 190,000 in the second half of 2016 and rose to 235,000 in February. In addition, the unemployment rate stood at $4.7 \%$ in February, which was within range of estimates of the US economy's natural rate of unemployment. US GDP growth, however, was weaker, with annualized growth in Q4 2016 at 1.9\% y-o-y, down from 3.5\% y-o-y in Q3 2016.

Inflation in the US has shown signs of firming. In full-year 2016 , consumer price inflation was $1.6 \%$, but it rose to $2.5 \% \mathrm{y}-\mathrm{o}-\mathrm{y}$ in January and $2.7 \mathrm{y}-\mathrm{o}-\mathrm{y}$ in February.

In February, Federal Reserve Chair Janet Yellen indicated that if these trends continue, an adjustment in the policy rate would be most likely, suggesting that the Federal Reserve will be accelerating the pace of its rate hike this year. Other statements from members of the Federal Reserve suggest the same. Cleveland Federal Reserve President Loretta Mester announced the following week that she would be comfortable with a rate hike if unemployment and inflation continue along their current trends. Federal Reserve Governor Jerome Powell noted that the US economy is currently near the Federal Reserve's employment targets and is on track to meet the inflation target.

In other advanced economies, downside risks have also diminished though some remain. In the eurozone, GDP growth for Q4 2016 was stable at 0.4\% q-o-q, the same rate as in the prior quarter. Inflation rose to $2.0 \% \mathrm{y}-\mathrm{o}-\mathrm{y}$ in February on rising energy prices as the underlying trend remained unchanged. Mario Draghi, President of the European Central Bank, said that monetary stimulus would still be needed to support the central bank's targets.

In Japan, the central bank raised its economic growth forecasts. For fiscal year 2016, the growth forecast was raised to $1.4 \%$ from $1.0 \%$, while for fiscal year 2017 it was raised to $1.5 \%$ from $1.3 \%$. For fiscal year 2018, the growth forecast was raised to $1.1 \%$ from $0.9 \%$. While there was no change in the forecast for consumer price inflation, the central bank noted that long-term inflation expectations had stopped declining.

Japan's GDP data showed that growth was unchanged at 0.3\% q-o-q in Q4 2016 from the previous quarter. Even more encouraging, exports from Japan increased $5.4 \%$ y-o-y in December and 1.3\% y-o-y in January following 14 months of $y-0-y$ declines, showing that global demand is improving.

In emerging East Asia, there are signs of improving growth in some markets. In Hong Kong, China, GDP growth rose to 3.1\% y-o-y in Q4 2016 from 2.0\% y-o-y in the prior quarter. Malaysia's GDP growth also accelerated to $4.5 \%$ y-o-y from $4.3 \%$ y-o-y over the same period. In Singapore, GDP grew 2.9\% y-o-y in Q4 2016, up from 1.2\% y-o-y growth in Q3 2016. Viet Nam reported GDP growth of $6.2 \%$ for 2016 , up from 5.9\% y-o-y growth in the first 3 quarters of 2016. As a result of the better growth outlook, risk appetite has been returning to the region.

The improved outlook has led to declines in 2-year yields in all markets except the PRC (Figures 6a, 6b). For 10-year yields, declines were noted in all markets except for the PRC, the Republic of Korea, the Philippines, and Thailand (Figures 7a, 7b). ${ }^{10}$

Improved investor sentiment was also evident in gains in foreign exchange and equity markets in most emerging East Asian economies. This has also led to downward shifts in most yield curves in the region (Figure 8). The yield curve shifted downward for all tenors in Hong Kong, China; Singapore; and Viet Nam; and for most tenors in Indonesia, the Republic of Korea, Malaysia, the Philippines, and Thailand. The PRC was the sole market where the entire yield curve shifted upward.

\footnotetext{
10 Bond yields in many emerging East Asian markets have rebounded slightly since the end of the review period (mid-February), largely due to the United States Federal Reserve's policy rate hike on 15 March. Nevertheless, regional bond yields were still mostly down year-to-date as of 15 March.
} 


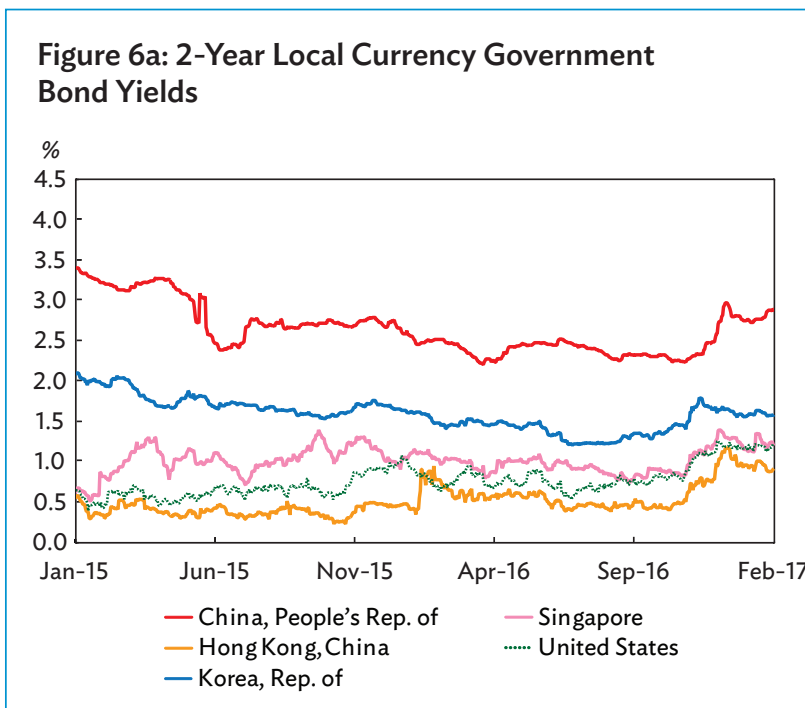

Note: Data as of 15 February 2017.

Source: Based on data from Bloomberg LP.

\section{Figure 6b: 2-Year Local Currency Government Bond Yields}

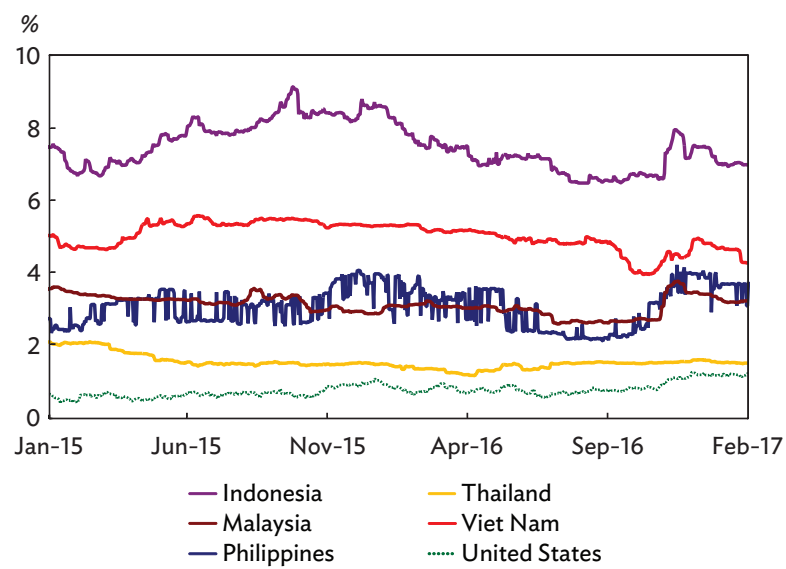

Note: Data as of 15 February 2017.

Source: Based on data from Bloomberg LP.

The PRC has been the exception to the fall in yields seen in most emerging East Asian markets as the People's Bank of China (PBOC) has been largely concerned with managing credit and asset price risk. In February, the $\mathrm{PBOC}$ raised rates on its repurchase agreements by 10 basis points (bps) and by 35 bps on its Standing Lending Facility.

The largest yield declines were seen in Indonesia, despite slower GDP growth in Q4 2016. This was largely due to improving market sentiments due to the current account deficit narrowing in Q4 2016, an upgrade in sovereign

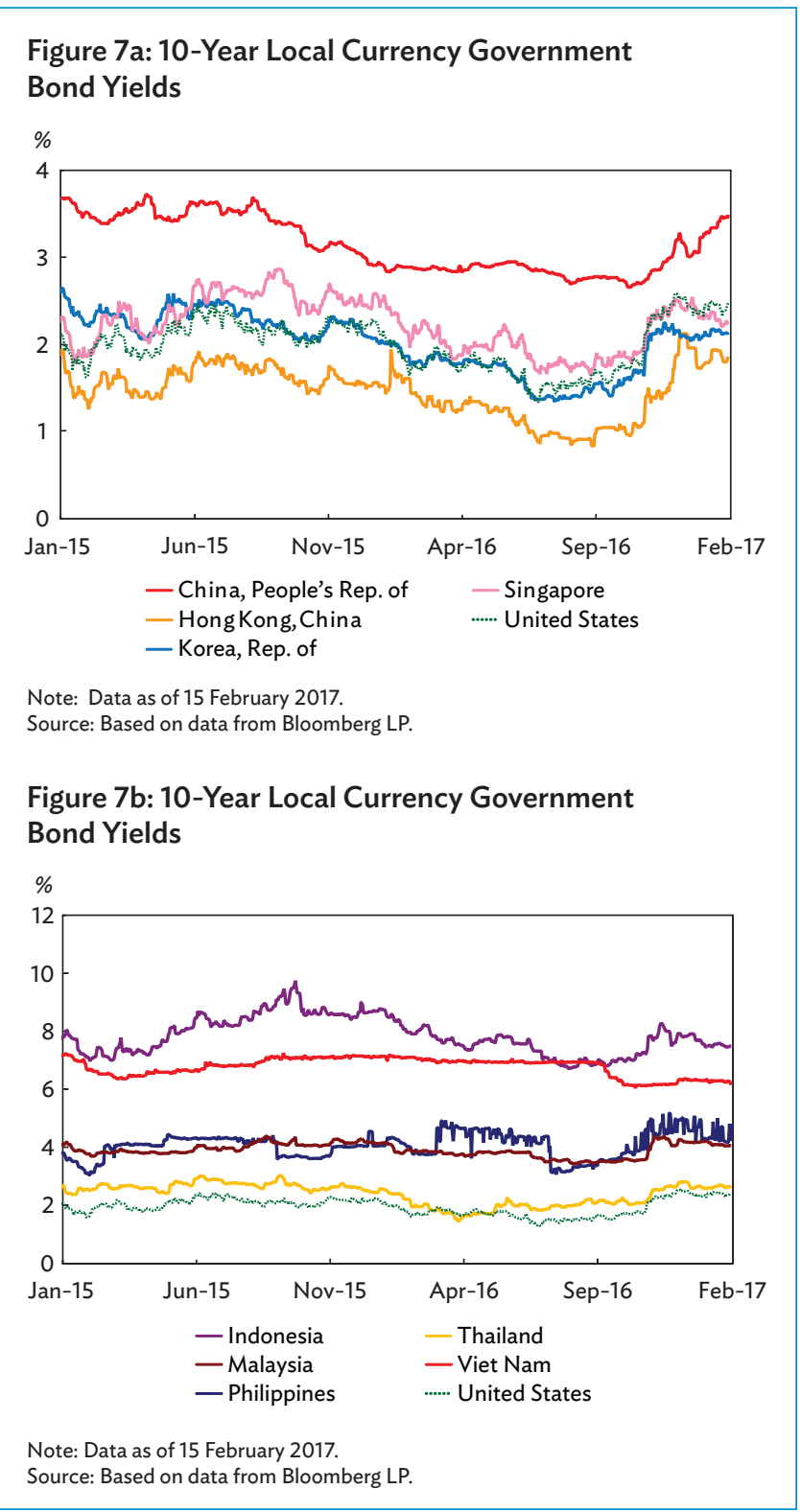

rating outlooks (Fitch Ratings in December and Moody's Investors Service in February 2017), higher international reserves, and various structural reforms initiated by the government.

In addition, improving economic growth and rising energy prices have resulted in steadily rising inflation rates.

Most emerging East Asian markets showed a rise in their inflation rate in January (Figures 9a). Rising prices have pushed Singapore out of deflation. Malaysia had the most rapid rise in y-o-y inflation in January versus December (Figure 9b). 
Figure 8: Benchmark Yield Curves-Local Currency Government Bonds
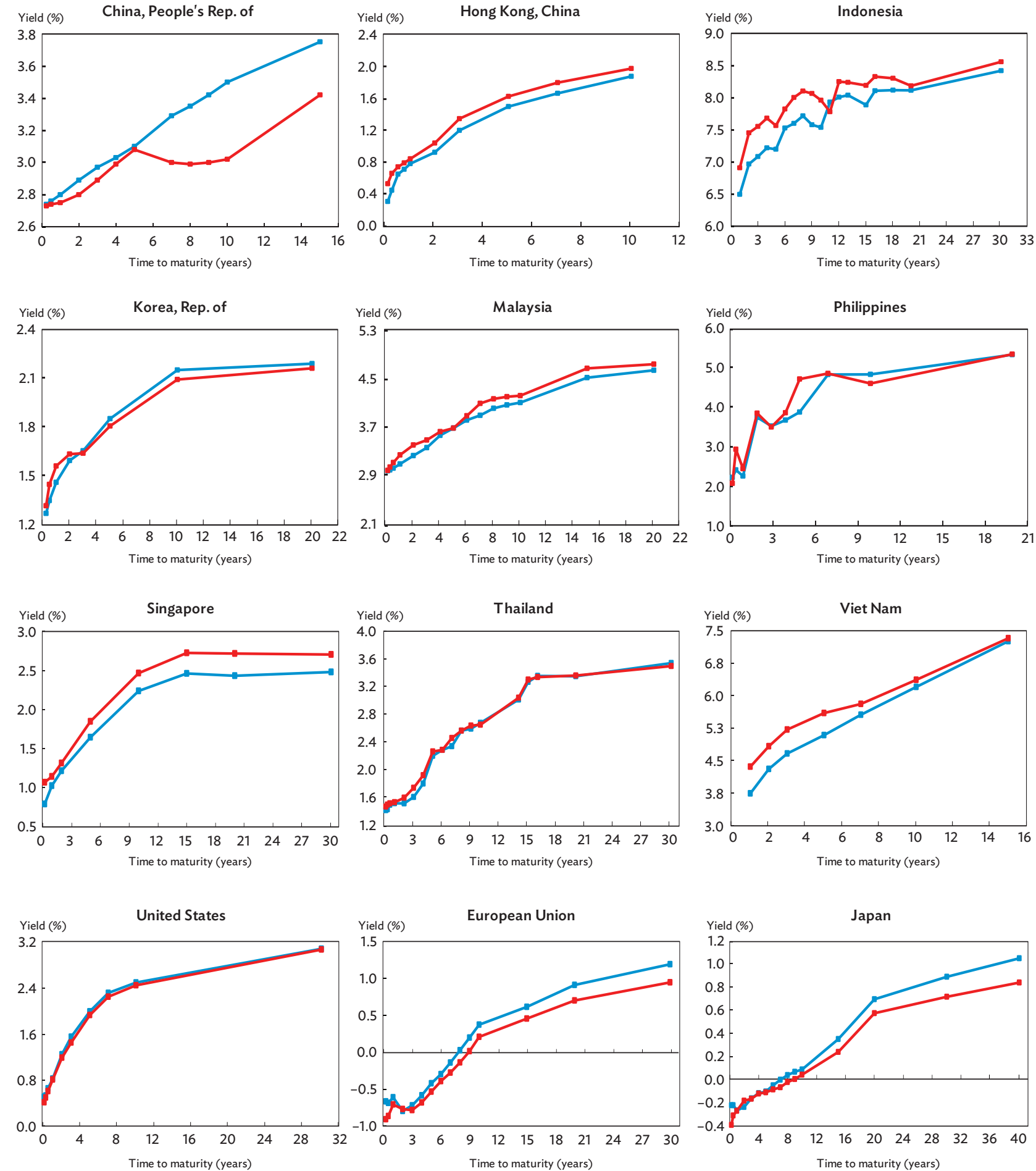

$-15-$ Feb-17

-31-Dec-16

Source: Based on data from Bloomberg LP. 
Figure 9a: Headline Inflation Rates

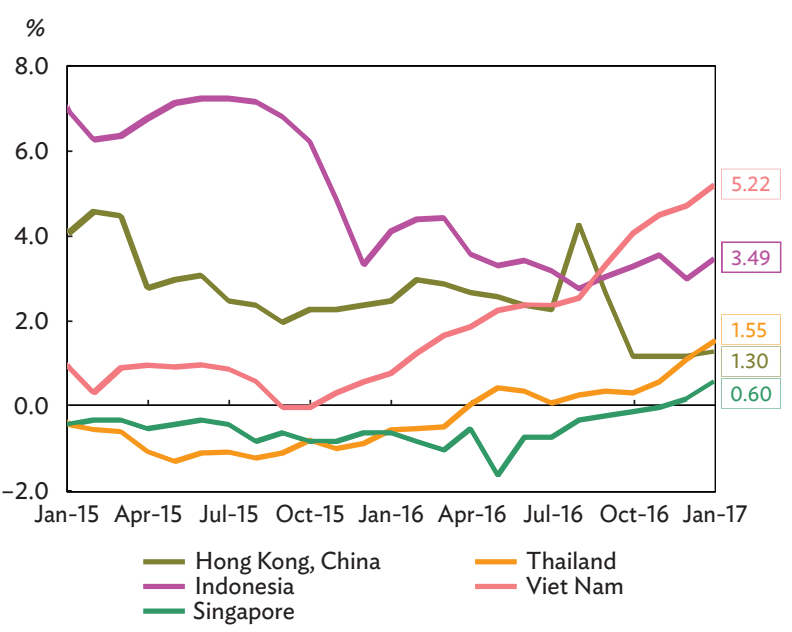

Note: Data as of January 2017.

Source: Based on data from Bloomberg LP.

\section{Figure 9b: Headline Inflation Rates}

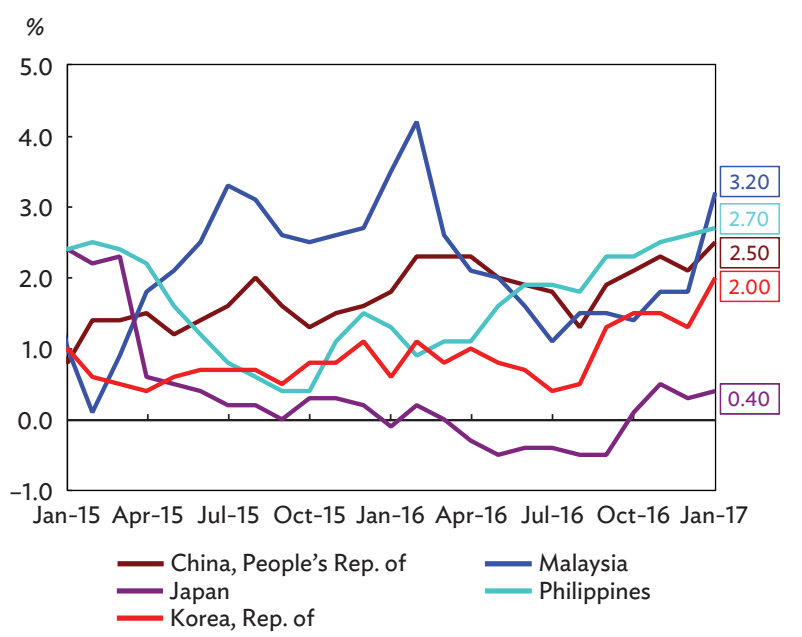

Note: Data as of January 2017.

Source: Based on data from Bloomberg LP.
While there have been improvements in the global economy, central banks have largely maintained their existing monetary policy stances while awaiting greater clarity on the possible direction and impacts of US monetary policy. Central bank policy rates were unchanged in Q4 2016 in all emerging East Asian markets except Hong Kong, China, which raised its policy rate in December following the Federal Reserve rate hike (Figures 10a, 10b). The PRC's policy rates were unchanged as the PBOC has been using other tools, such as adjusting rates on reverse repurchase agreements, to guide monetary policy.

Given the improved economic prospects, the 2-year versus 10 -year yield spread rose in nearly all regional markets except for Singapore between 31 December and 15 February (Figure 11).

\section{Figure 10a: Policy Rates}

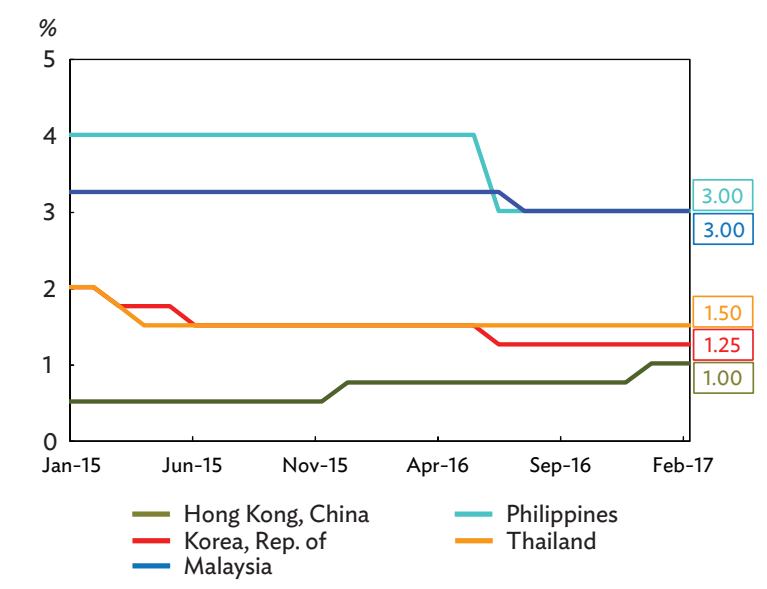

Notes:

1. Data as of 15 February 2017.

2. The policy rate of the Philippines was adjusted to $3.0 \%$ from $4.0 \%$ in June following the shift in the Bangko Sentral ng Pilipinas' monetary operations to an interest rate corridor system.

Source: Based on data from Bloomberg LP.
Figure 10b: Policy Rates

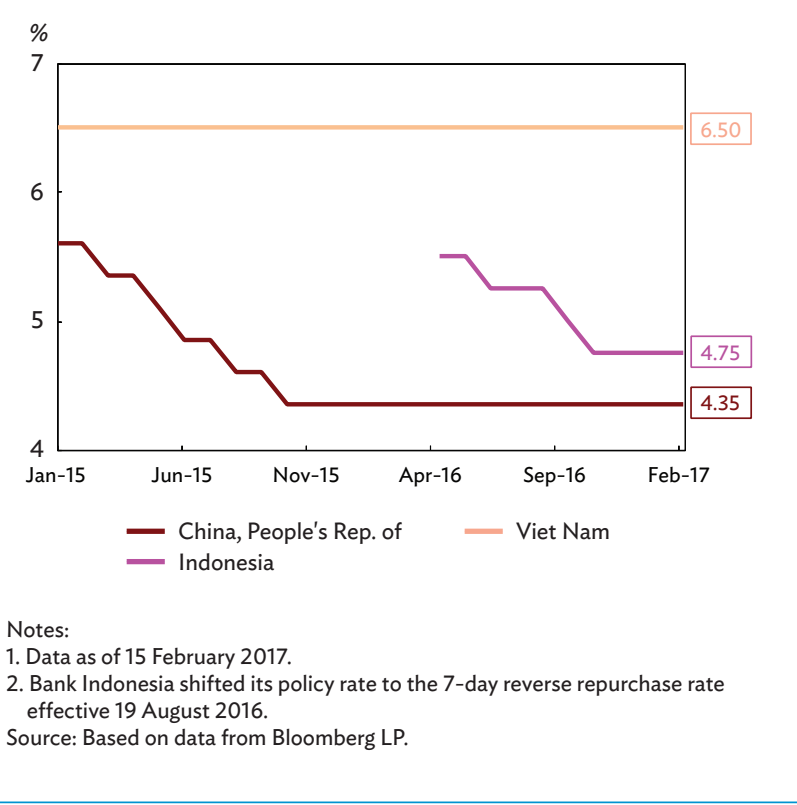




\section{Figure 11: Yield Spreads Between 2-Year and 10-Year Government Bonds}

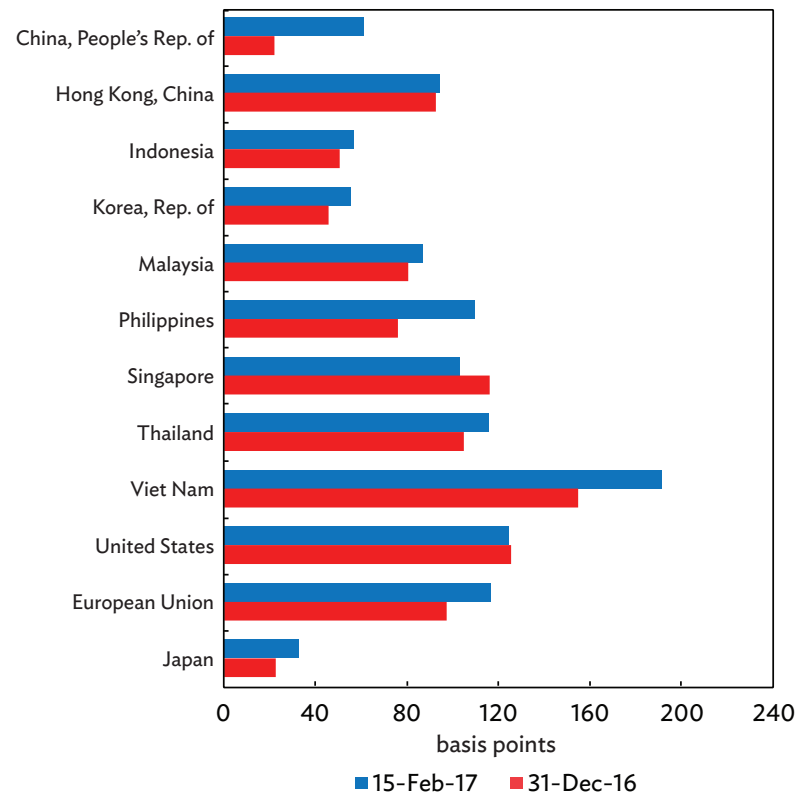

Source: Based on data from Bloomberg LP.
The AAA-rated corporate yield versus government yield spread fell in the PRC and the Republic of Korea, but rose in Malaysia.

Yield spreads of AAA-rated corporate yields versus government yields fell between 31 December and 15 February in the PRC on the back of improving confidence as the PBOC attempts to reduce leverage in the financial system. Improving investor sentiments in the Republic of Korea also led to a decline in spreads over the same period (Figure 12a). Malaysia was one of the few bond markets that experienced outflows in the early part of 2017, leading to a rise in AAA-rated credit spreads for most tenors.

In all three markets for which data are available, the yield spreads between AAA-rated corporates and lower-rated corporates were mostly unchanged between 31 December and 15 February (Figure 12b).

Figure 12a: Credit Spreads-Local Currency Corporates Rated AAA vs. Government Bonds
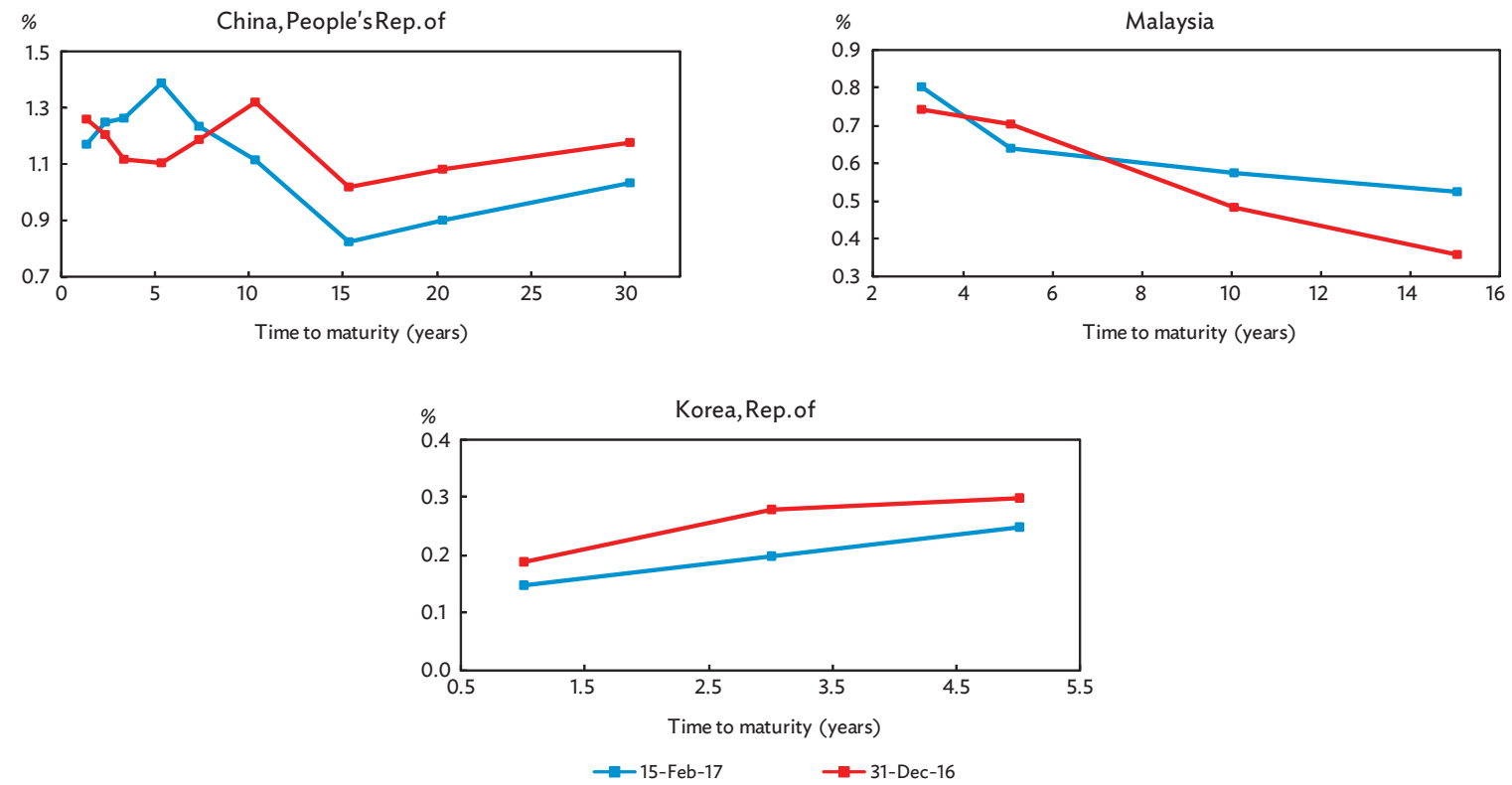

Notes:

1. Credit spreads are obtained by subtracting government yields from corporate indicative yields.

2. For Malaysia, data on corporate bond yields are as of 30 December 2016 and 14 February 2017.

Sources: People's Republic of China (Wind Information), Republic of Korea (EDAILY BondWeb), and Malaysia (Bank Negara Malaysia). 
Figure 12b: Credit Spreads-Lower-Rated Local Currency Corporates vs. AAA
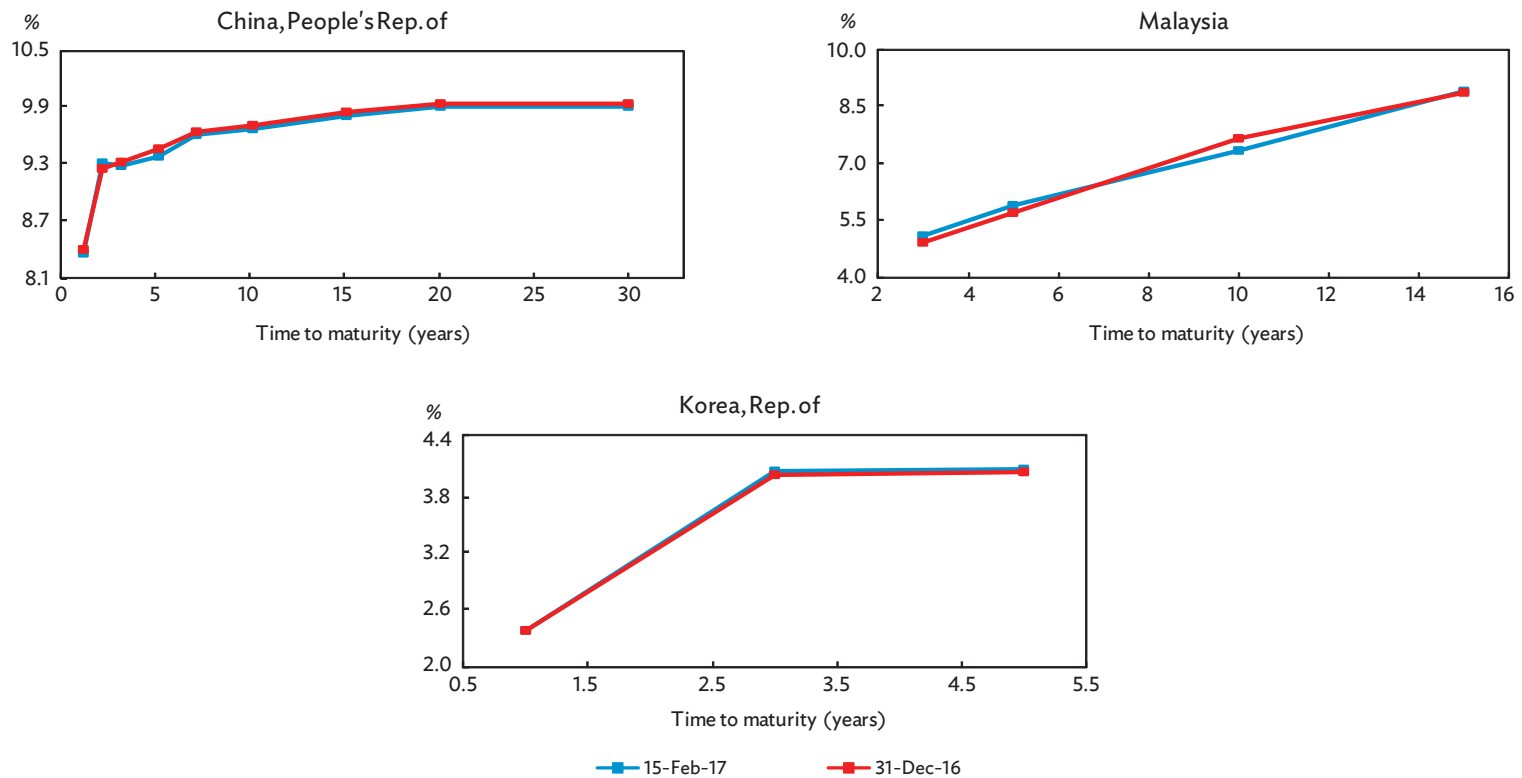

Notes:

1. For the People's Republic of China and the Republic of Korea, credit spreads are obtained by subtracting corporate indicative yields rated AAA from corporate indicative yields rated $\mathrm{BBB}+$.

2. For Malaysia, credit spreads are obtained by subtracting corporate indicative yields rated AAA from corporate indicative yields rated BBB.

3. For Malaysia, data on corporate bond yields are as of 30 December 2016 and 14 February 2017.

Sources: People's Republic of China (Wind Information), Republic of Korea (EDAILY BondWeb), and Malaysia (Bank Negara Malaysia). 


\section{Policy and Regulatory Developments}

\section{People's Republic of China}

People's Bank of China Lowers Reporting Threshold for Certain Financial Transactions

In December, the People's Bank of China lowered the threshold-from CNY200,000 to CNY50,000-at which banks must notify the central bank of any domestic deposit, withdrawal, or transfer. In addition, the central bank announced that banks must report to the central bank cross-border transfers of CNY200,000 and above.

The People's Republic of China Allows Foreign Investors to Invest in Currency Derivatives

In February, the People's Republic of China's State Administration of Foreign Exchange announced that it would allow foreign institutions investing in the People's Republic of China's interbank bond market to purchase currency forwards, currency swaps, cross-currency swaps, and currency options. Investors will be only allowed to purchase these derivatives to hedge their bond investments.

\section{Hong Kong, China}

\section{Hong Kong Monetary Authority Raises Countercyclical Capital Requirement for Banks}

In January, the Hong Kong Monetary Authority raised the countercyclical capital buffer requirement for banks from $1.25 \%$ to $1.875 \%$ as part of its implementation of Basel III. The Hong Kong Monetary Authority said that domestic risks remain due to current credit levels and property prices.

\section{Indonesia}

\section{Ministry of Finance Announces Government Bond Issuance Plan for 2017}

In November, the Ministry of Finance announced that it would continue its frontloading policy for the issuance of government bonds in 2017. The ministry plans to issue about $60 \%$ of its gross issuance target for 2017 in the first
7 months of the year. The adoption of the frontloading policy aims to provide funding for government expenditures in the early part of the year given the seasonality in the timing of government revenues. The government bond issuance plan for 2017 calls for 20\% of the total to be raised from the international market and the remaining from the domestic market. In the first quarter of 2017, the government is looking to raise IDR155 trillion worth of conventional and Islamic government bonds.

Bank Indonesia Signs Memoranda of Understanding with Bank Negara Malaysia and Bank of Thailand to Promote Local Currency Settlement Framework

Bank Indonesia, Bank Negara Malaysia (BNM), and the Bank of Thailand (BOT) signed two memoranda of understanding in December to promote the settlement of cross-border trade and direct investment in their respective local currencies. The agreements' goal is to help reduce financial costs and improve trade and investment.

\section{Republic of Korea}

\section{Financial Services Commission Announces Measures to Improve Derivatives Market}

In November, the Financial Services Commission announced measures to further develop the Republic of Korea's derivatives markets, including the simplification of the listing procedures and diversification of derivatives that can be issued in the exchange-traded derivatives market and increased flexibility in the requirements for investors. For the over-the-counter (OTC) derivatives market, Korea Exchange will allow certain non KRWdenominated OTC derivatives to be centrally cleared in the exchange. The Financial Services Commission will also consider introducing electronic trading platforms for the OTC derivatives market and will continue to strengthen risk management of both equity-linked and derivativeslinked securities by conducting regular stress tests of securities firms. 
The Republic of Korea Will Frontload Spending in the First Half of 2017

In December, the Republic of Korea's Ministry of Strategy and Finance announced that it will frontload the spending of $68.0 \%$ of the government's 2017 budget of KRW339.7 trillion in the first half of the year. KRW123.4 trillion (36.3\%) will be spent in the first quarter and KRW107.5 trillion (31.7\%) in the second quarter. According to the ministry, the frontloading will be used to spur economic growth, with allocations earmarked for increasing employment, completing Social Overhead Capital projects, and improving safety.

\section{Malaysia}

\section{Bank Negara Malaysia Restricts Activities} in the Nondeliverable Forward Market

In November, BNM moved to discourage trading of Malaysian ringgit in the nondeliverable forward (NDF) market. The central bank sees it as speculative activity that can potentially destabilize the Malaysian ringgit. According to $\mathrm{BNM}$, while the foreign exchange administration is unchanged and no new measures were introduced, existing rules that prohibit facilitation of Malaysian ringgit NDFs will be reinforced. Transactions relating to offshore Malaysian ringgit NDF market activities will not be recognized as the Malaysian ringgit is not an internationalized currency.

\section{Exporters Can Retain Up to 25\% of Proceeds in Foreign Currency}

On 2 December, BNM announced that exporters can retain up to $25 \%$ of export proceeds in a foreign currency and the rest must be converted to Malaysian ringgit. Exporters may hold higher balances in a foreign currency to meet payment requirements with approval from BNM. A special deposit facility is being offered by BNM for Malaysian ringgit proceeds that pays a higher deposit rate of $3.25 \%$ per annum. The facility will be available until 31 December 2017 and is subject to further review. Other BNM measures include a requirement that domestic trade in goods and services by resident exporters be paid in Malaysian ringgit and that exporters are allowed to hedge and unhedge up to 6 months of their foreign currency obligations.

\section{Philippines}

Government Set to Borrow PHP631.3 billion in 2017

The Government of the Philippines plans to borrow PHP631.3 billion in 2017 to support its expenditures and loan payments. Of the total amount, $80 \%$ will come from domestic borrowing and $20 \%$ will be tapped from foreign sources. The government will boost its spending, particularly in infrastructure, to sustain the economy's growth momentum. It plans to raise the budget deficit to about 3\% of gross domestic product in 2017.

\section{Bangko Sentral ng Pilipinas Discontinues Trust Entities' Access to Deposit Facility}

Bangko Sentral ng Pilipinas (BSP) decided in November to discontinue the access of trust entities to its Overnight Deposit Facility and Term Deposit Facility beginning 1 July 2017 in an effort to rationalize the use of the deposit facility as a liquidity management tool.

\section{Bangko Sentral ng Pilipinas Will Adopt Liquidity Coverage Ratio Framework}

Universal and commercial banks will formally adopt a Liquidity Coverage Ratio beginning 1 January 2018 as part of the BSP's move to liberalize liquidity rules. According to the BSP, once the formal adoption is in place, the following guidelines could be lifted: (i) liquid assets should be equivalent to at least half of government deposits and other liabilities, (ii) foreign-currency-denominated liquid assets should be equivalent to at least $30 \%$ of foreign currency deposit unit liabilities, and (iii) foreigncurrency-denominated assets should be equivalent to $70 \%$ of foreign currency deposit unit liabilities in the same currency as the liability. The Liquidity Coverage Ratio framework will require universal and commercial banks to hold sufficient high-quality liquid assets that can easily be converted into cash to service liquidity requirements over a 30-day stress period.

\section{Singapore}

\section{Monetary Authority of Singapore Launches Asian Bond Grant Scheme}

On 17 November, the Monetary Authority of Singapore announced its Asian Bond Grant Scheme that will run 
from 2017 until 2019. To qualify under the scheme, the following criteria, among others, must be met: (i) issuers should be a first-time Asian company or nonbank financial institution with global headquarters in a member of the Association of Southeast Asian Nations, Australia, the People's Republic of China, India, Japan, the Republic of Korea, or New Zealand; (ii) bond issuance must be at least SGD200 million (or its equivalent in the respective local currency or a G3 currency); and (iii) bonds must have a maturity of at least 3 years. Also, the bonds should be listed on the Singapore Exchange, while SGD-denominated bonds should be rated by either Fitch Ratings, Moody's Investors Service, or Standard and Poor's.

Those who meet these criteria may apply for the grant to help offset $50 \%$ of the one-time issuance costs, which include international legal fees, arrangers' fees, auditors' fees, credit rating fees, and listing fees. The objective of the scheme is to broaden the issuer base in the Singapore bond market.

Monetary Authority of Singapore and Bank of Japan Establish Bilateral Local Currency Swap Agreement

On 30 November, the Monetary Authority of Singapore and Bank of Japan signed an agreement allowing for the exchange of local currencies of up to SGD15 billion or JPY1.1 trillion. The swap agreement, which will be in effect for 3 years, aims to enhance financial stability and provide liquidity to cross-border transactions of financial institutions based in both markets.

\section{Thailand}

\section{Thailand's Securities and Exchange Commission Strengthens Measures against Shadow Banking}

Thailand's Securities and Exchange Commission introduced a measure, effective 16 January, limiting intermediary holdings to one third for every new issuance of unrated debt securities falling below investment grade. In addition, intermediaries are restricted from being the main creditor of the debt issuer. Intermediaries are given 120 days to comply and are instructed to examine the quality of the unrated debt securities, verify and conduct due diligence regarding the issuer's financial health, and make the information available to investors.
According to the Securities and Exchange Commission, the regulation is meant to stop intermediaries, such as asset management firms, from getting involved in shadow banking activities, especially with regard to unrated noninvestment grade debt.

\section{Bank of Thailand Releases Planned Issuance} Program for Bonds in the First Half of 2017

For the first half of 2017, the BOT announced that auction days and issuance frequencies for all types of BOT bonds will remain unchanged from the previous year. A new issue of the 3-year floating-rate bond was opened in February, while the opening of new 1-year bills will be moved to the last month of each quarter to accommodate seasonal liquidity factors and the monthly reopenings will continue to enhance secondary market liquidity. Beginning in the second quarter of 2017, the BOT plans to introduce a postauction option for successful competitive bidders of bonds with maturities of at least 1 year in which additional purchases will be possible at a weighted-average accepted yield.

\section{Viet Nam}

\section{Ministry of Finance to Submit 2017-2020 Roadmap for the Local Currency Bond Market}

In January, Viet Nam's Ministry of Finance disclosed that it plans to submit its 4-year roadmap for the local currency bond market. The 2017-2020 roadmap is expected to improve fiscal and monetary policy coordination for better supervision of Viet Nam's financial markets. The roadmap includes, among other activities, the launch of bond derivatives in the first quarter of 2017, issuance of floating-rate government bonds in the second quarter, and creation of a corporate bond database to provide greater transparency.

Viet Nam to Issue VND183.3 Trillion of Government Bonds in 2017

In February, the State Treasury of Viet Nam announced its bond issuance plan for 2017 amounting to VND183.3 trillion. Of the total issuance, $15 \%$ will comprise bonds with maturities of 3 years or less, $60 \%$ will comprise bonds with maturities of between 5 years and 10 years, and the remaining $25 \%$ will comprise bonds with maturities of 15 years to 30 years. 


\section{Market Summaries}

\section{People's Republic of China}

The amount of local currency (LCY) bonds outstanding in the People's Republic of China (PRC) grew $3.4 \%$ quarter-on-quarter (q-o-q) and $22.0 \%$ year-on-year ( $y-0-y)$ to reach CNY49.5 trillion (USD7.1 trillion) at the end of December. The expansion was driven mostly by Treasury bonds and other government bonds, which grew 5.9\% q-o-q and $47.8 \%$ y-o-y. Growth in the latter category was fueled mainly by local government bonds, which grew 9.3\% q-o-q and $220.2 \%$ y-o-y as local governments continued to refinance existing debt and issue new bonds. Central bank bonds outstanding were substantially lower at the end of December; the People's Bank of China has ceased issuing bonds as remaining bonds mature.

Table 1: Size and Composition of the Local Currency Bond Market in the People's Republic of China

\begin{tabular}{|c|c|c|c|c|c|c|c|c|c|c|}
\hline & \multicolumn{6}{|c|}{ Outstanding Amount (billion) } & \multicolumn{4}{|c|}{ Growth Rates (\%) } \\
\hline & \multicolumn{2}{|c|}{ Q4 2015} & \multicolumn{2}{|c|}{ Q3 2016} & \multicolumn{2}{|c|}{ Q4 2016} & \multicolumn{2}{|c|}{ Q4 2015} & \multicolumn{2}{|c|}{ Q4 2016} \\
\hline & CNY & USD & CNY & USD & CNY & USD & $q-0-q$ & $y-0-y$ & $q-o-q$ & $y-0-y$ \\
\hline Total & 40,576 & 6,248 & 47,890 & 7,178 & 49,510 & 7,129 & 6.8 & 24.0 & 3.4 & 22.0 \\
\hline Government & 26,408 & 4,067 & 33,154 & 4,969 & 34,545 & 4,974 & 7.6 & 27.6 & 4.2 & 30.8 \\
\hline Treasury Bonds & 14,984 & 2,307 & 20,912 & 3,134 & 22,142 & 3,188 & 13.0 & 45.4 & 5.9 & 47.8 \\
\hline Central Bank Bonds & 428 & 66 & 27 & 4 & 6 & 1 & 0.0 & 0.0 & $(78.2)$ & $(98.6)$ \\
\hline Policy Bank Bonds & 10,996 & 1,693 & 12,215 & 1,831 & 12,397 & 1,785 & 1.3 & 10.4 & 1.5 & 12.7 \\
\hline Corporate & 14,168 & 2,182 & 14,736 & 2,209 & 14,965 & 2,155 & 5.3 & 17.8 & 1.6 & 5.6 \\
\hline \multicolumn{11}{|l|}{ Policy Bank Bonds } \\
\hline China Development Bank & 6,601 & 1,017 & 7,051 & 1,057 & 7,081 & 1,020 & $(0.1)$ & 5.4 & 0.4 & 7.3 \\
\hline Export-Import Bank of China & 1,852 & 285 & 2,028 & 304 & 2,133 & 307 & 1.9 & 16.9 & 5.2 & 15.2 \\
\hline Agricultural Devt. Bank of China & 2,543 & 392 & 3,136 & 470 & 3,184 & 458 & 4.7 & 20.6 & 1.5 & 25.2 \\
\hline
\end{tabular}

$($ ) = negative, $C N Y=$ Chinese yuan, $L C Y=$ local currency, $q-o-q=$ quarter-on-quarter, $Q 3=$ third quarter, $Q 4=$ fourth quarter, USD = United States dollar, $y$-o-y = year-on-year. Notes:

1. Calculated using data from national sources.

2. Treasury bonds include savings bonds and local government bonds.

3. Bloomberg LP end-of-period LCY-USD rate is used.

4. Growth rates are calculated from an LCY base and do not include currency effects.

Sources: Bloomberg LP, ChinaBond, and Wind Information.

Corporate bond issuance totaled CNY1.5 trillion in the fourth quarter of 2016 on $0.6 \%$ q-o-q growth as some companies were hesitant to borrow amidst tighter liquidity.

Table 2: Notable Local Currency Corporate Bond Issuance in the Fourth Quarter of 2016

\begin{tabular}{|c|c|c|c|c|c|}
\hline Corporate Issuers & $\begin{array}{c}\text { Coupon Rate } \\
(\%)\end{array}$ & $\begin{array}{l}\text { Issued Amount } \\
\text { (CNY billion) }\end{array}$ & Corporate Issuers & $\begin{array}{c}\text { Coupon Rate } \\
(\%)\end{array}$ & $\begin{array}{l}\text { Issued Amount } \\
\text { (CNY billion) }\end{array}$ \\
\hline China Railway & & & 1-year bond & 2.99 & 10.0 \\
\hline 10-year bond & 3.01 & 15.0 & 3-year bond & 2.80 & 5.0 \\
\hline 10-year bond & 3.35 & 15.0 & 3-year bond & 2.80 & 5.0 \\
\hline 10-year bond & 3.00 & 15.0 & 3-year bond & 2.99 & 5.0 \\
\hline 10-year bond & 3.69 & 15.0 & 5-year bond & 2.99 & 5.0 \\
\hline 10-year bond & 3.10 & 15.0 & 5-year bond & 3.15 & 5.0 \\
\hline 20-year bond & 3.54 & 5.0 & Bank of Communications & & \\
\hline 20-year bond & 3.31 & 5.0 & 3-year bond & 2.94 & 10.0 \\
\hline 20-year bond & 3.88 & 5.0 & 5-year bond & 3.25 & 20.0 \\
\hline 30-year bond & 3.40 & 5.0 & Postal Savings Bank of China & & \\
\hline 30-year bond & 3.53 & 5.0 & 10-year bond & 3.30 & 30.0 \\
\hline State Grid Corporation of China & & & China Huarong Asset Management & & \\
\hline 178-day bond & 2.59 & 5.0 & 3-year bond & 3.35 & 12.5 \\
\hline 180-day bond & 3.49 & 5.0 & 5-year bond & 3.54 & 12.5 \\
\hline
\end{tabular}


LCY corporate bonds outstanding among the top 30 corporate bond issuers in the PRC reached

CNY6.0 trillion at the end of December, accounting for about $40 \%$ of the total LCY corporate bond market.

The largest issuer remained China Railway with CNY1.4 trillion of bonds outstanding.

Table 3: Top 30 Issuers of Local Currency Corporate Bonds in the People's Republic of China

\begin{tabular}{|c|c|c|c|c|c|c|}
\hline & & Outstanc & Amount & & & \\
\hline & Issuers & $\begin{array}{l}\text { LCY Bonds } \\
\text { (CNY billion) }\end{array}$ & $\begin{array}{l}\text { LCY Bonds } \\
\text { (USD billion) }\end{array}$ & Owned & Company & Type of Industry \\
\hline 1. & China Railway & $1,363.5$ & 196.33 & Yes & No & Transportation \\
\hline 2. & State Grid Corp of China & 497.1 & 71.58 & Yes & No & Public Utilities \\
\hline 3. & China National Petroleum & 365.0 & 52.56 & Yes & No & Energy \\
\hline 4. & Agricultural Bank of China & 278.0 & 40.03 & Yes & Yes & Banking \\
\hline 5. & Industrial \& Commercial Bank of China & 268.0 & 38.59 & Yes & Yes & Banking \\
\hline 6. & Bank of China & 258.9 & 37.27 & Yes & Yes & Banking \\
\hline 7. & Industrial Bank & 231.0 & 33.26 & No & Yes & Banking \\
\hline 8. & Bank of Communications & 224.0 & 32.25 & No & Yes & Banking \\
\hline 9. & China Construction Bank & 212.0 & 30.53 & Yes & Yes & Banking \\
\hline 10. & Shanghai Pudong Development Bank & 184.6 & 26.58 & No & Yes & Banking \\
\hline 11. & PetroChina & 181.0 & 26.06 & Yes & Yes & Energy \\
\hline 12. & China Minsheng Banking & 175.1 & 25.21 & No & Yes & Banking \\
\hline 13. & State Power Investment & 162.2 & 23.36 & Yes & No & Energy \\
\hline 14. & Bank of Beijing & 122.9 & 17.70 & Yes & Yes & Banking \\
\hline 15. & Central Huijin Investment & 109.0 & 15.69 & Yes & No & Asset Management \\
\hline 16. & China CITIC Bank & 107.5 & 15.48 & No & Yes & Banking \\
\hline 17. & Shenhua Group & 104.5 & 15.05 & Yes & No & Energy \\
\hline 18. & China Huarong Asset Management & 102.0 & 14.69 & Yes & Yes & Asset Management \\
\hline 19. & China Three Gorges & 97.5 & 14.04 & Yes & No & Public Utilities \\
\hline 20. & Shaanxi Coal and Chemical Industry Group & 97.0 & 13.97 & Yes & Yes & Energy \\
\hline 21. & China United Network Communications & 97.0 & 13.97 & Yes & Yes & Telecommunications \\
\hline 22. & $\begin{array}{l}\text { Tianjin Infrastructure Construction } \\
\text { \& Investment Group }\end{array}$ & 94.9 & 13.66 & Yes & No & Industrial \\
\hline 23. & China Petroleum \& Chemical & 94.5 & 13.61 & Yes & Yes & Energy \\
\hline 24. & China Datang & 91.7 & 13.20 & Yes & Yes & Energy \\
\hline 25. & China Everbright Bank & 89.0 & 12.81 & Yes & Yes & Banking \\
\hline 26. & China Guangfa Bank & 86.5 & 12.46 & No & Yes & Banking \\
\hline 27. & Guotai Junan Securities & 85.0 & 12.24 & Yes & Yes & Brokerage \\
\hline 28. & Haitong Securities & 84.0 & 12.10 & Yes & Yes & Brokerage \\
\hline 29. & $\begin{array}{l}\text { Beijing State-owned Capital Operation } \\
\text { and Management Center }\end{array}$ & 80.5 & 11.59 & Yes & No & Asset Management \\
\hline 30. & Huaxia Bank & 80.4 & 11.58 & Yes & No & Banking \\
\hline Tot & I Top 30 LCY Corporate Issuers & $6,024.30$ & 867.43 & & & \\
\hline Tot & LCY Corporate Bonds & $14,964.97$ & $2,154.78$ & & & \\
\hline Top & 30 as $\%$ of Total LCY Corporate Bonds & $40.3 \%$ & $40.3 \%$ & & & \\
\hline
\end{tabular}

CNY $=$ Chinese yuan, $\mathrm{LCY}=$ local currency, USD = United States dollar

Notes:

1. Data as of end-December 2016

2. State-owned firms are defined as those in which the government has more than a $50 \%$ ownership stake.

Source: AsianBondsOnline calculations based on Bloomberg LP data. 


\section{Hong Kong, China}

The amount of local currency (LCY) bonds outstanding in Hong Kong, China increased to HKD1.8 trillion (USD236 billion) at the end of December. Total bonds outstanding grew only $0.1 \%$ quarter-on-quarter (q-o-q), due to declines in Exchange Fund Notes and Hong Kong Special Administrative Region bonds, and $13.4 \%$ year-on-year $(y-0-y)$. Among government bonds, only Exchange Fund Bills showed an increase, rising $0.4 \%$ q-o-q and $18.8 \%$ y-o-y.

Table 1: Size and Composition of the Local Currency Bond Market in Hong Kong, China

\begin{tabular}{|c|c|c|c|c|c|c|c|c|c|c|}
\hline & \multicolumn{6}{|c|}{ Outstanding Amount (billion) } & \multicolumn{4}{|c|}{ Growth Rate (\%) } \\
\hline & \multicolumn{2}{|c|}{ Q4 2015} & \multicolumn{2}{|c|}{ Q3 2016} & \multicolumn{2}{|c|}{ Q4 2016} & \multicolumn{2}{|c|}{ Q4 2015} & \multicolumn{2}{|c|}{ Q4 2016} \\
\hline & HKD & USD & HKD & USD & HKD & USD & $q-o-q$ & $y-0-y$ & $q-0-q$ & $y-0-y$ \\
\hline Total & 1,616 & 208 & 1,830 & 236 & 1,832 & 236 & 4.2 & 7.3 & 0.1 & 13.4 \\
\hline Government & 927 & 120 & 1,067 & 138 & 1,064 & 137 & 5.8 & 9.2 & $(0.3)$ & 14.8 \\
\hline Exchange Fund Bills & 770 & 99 & 911 & 117 & 915 & 118 & 8.2 & 12.6 & 0.4 & 18.8 \\
\hline Exchange Fund Notes & 59 & 8 & 51 & 7 & 48 & 6 & $(4.9)$ & $(14.7)$ & $(5.9)$ & (17.7) \\
\hline HKSAR Bonds & 99 & 13 & 105 & 14 & 101 & 13 & $(4.2)$ & 2.5 & $(3.8)$ & 2.4 \\
\hline Corporate & 689 & 89 & 764 & 98 & 767 & 99 & 2.0 & 4.8 & 0.5 & 11.5 \\
\hline
\end{tabular}

()$=$ negative, HKD = Hong Kong dollar, HKSAR = Hong Kong Special Administrative Region, LCY = local currency, q-o-q = quarter-on-quarter, Q3 = third quarter, Q4 = fourth quarter, USD = United States dollar, $y-0-y=$ year-on-year. Notes:

1. Calculated using data from national sources.

2. Bloomberg LP end-of-period LCY-USD rates are used.

3. Growth rates are calculated from an LCY base and do not include currency effects.

Sources: Hong Kong Monetary Authority and Bloomberg LP.

Corporate bond issuance totaled HKD85.5 billion in the fourth quarter of 2016, up from HKD67.1 billion in the prior quarter, as companies locked in borrowing rates ahead of expected Federal Reserve rate hikes.

Table 2: Notable Local Currency Corporate Bond Issuance in the Fourth Quarter of 2016

\begin{tabular}{lcc}
\multicolumn{1}{c}{ Corporate Issuers } & $\begin{array}{c}\text { Coupon Rate } \\
(\%)\end{array}$ & $\begin{array}{c}\text { Issued Amount } \\
\text { (HKD billion) }\end{array}$ \\
$\begin{array}{l}\text { Hong Kong Mortgage Corporation } \\
\text { 2-year bond }\end{array}$ & 1.00 & 0.10 \\
3-year bond & 1.60 & 0.35 \\
\hline Swire Pacific MTN Financing & & \\
5-year bond & 1.98 & 0.45 \\
\hline Hong Kong Interbank Clearing & & 0.20 \\
3-year bond & 1.45 & 0.20 \\
5-year bond & 1.85 & \\
\hline
\end{tabular}

HKD = Hong Kong dollar, MTN = medium-term note.

Source: Central Moneymarkets Unit, Hong Kong Monetary Authority. 
LCY corporate bonds outstanding among the top 30 nonbank corporate bond issuers in Hong Kong, China reached HKD136.3 billion at the end of December, accounting for about 17.8\% of the total LCY corporate bond market. The largest issuer remained Hong Kong Mortgage Corporation, with HKD24.0 billion of bonds outstanding.

Table 3: Top 30 Nonbank Issuers of Local Currency Corporate Bonds in Hong Kong, China

\begin{tabular}{|c|c|c|c|c|c|c|}
\hline & & Outstand & g Amount & & & \\
\hline & Issuers & $\begin{array}{l}\text { LCY Bonds } \\
\text { (HKD billion) }\end{array}$ & $\begin{array}{l}\text { LCY Bonds } \\
\text { (USD billion) }\end{array}$ & Owned & Company & Type of Industry \\
\hline 1. & The Hong Kong Mortgage Corporation & 24.04 & 3.10 & Yes & No & Finance \\
\hline 2. & Sun Hung Kai Properties (Capital Market) & 9.35 & 1.21 & No & No & Real Estate \\
\hline 3. & Swire Pacific MTN Financing & 8.62 & 1.11 & No & Yes & Diversified \\
\hline 4. & The Link Finance (Cayman) 2009 & 8.09 & 1.04 & No & No & Finance \\
\hline 5. & CLP Power Hong Kong Financing & 7.81 & 1.01 & No & No & Finance \\
\hline 6. & HKCG (Finance) & 7.80 & 1.01 & No & No & Finance \\
\hline 7. & Hongkong Electric Finance & 7.69 & 0.99 & No & No & Finance \\
\hline 8. & MTR Corporation (C.I.) & 7.02 & 0.91 & Yes & Yes & Transportation \\
\hline 9. & Wharf Finance & 5.70 & 0.73 & No & No & Finance \\
\hline 10. & NWD (MTN) & 5.50 & 0.71 & No & Yes & Finance \\
\hline 11. & Swire Properties MTN Financing & 4.34 & 0.56 & No & No & Finance \\
\hline 12. & Vanke Real Estate (Hong Kong) & 3.65 & 0.47 & No & No & Real Estate \\
\hline 13. & Wheelock Finance & 3.60 & 0.46 & No & No & Finance \\
\hline 14. & Kowloon-Canton Railway & 3.40 & 0.44 & Yes & No & Transportation \\
\hline 15. & Urban Renewal Authority & 3.30 & 0.43 & Yes & No & Real Estate \\
\hline 16. & Emperor International Holdings & 2.75 & 0.35 & No & Yes & Real Estate \\
\hline 17. & Cathay Pacific MTN Financing & 2.70 & 0.35 & No & Yes & Finance \\
\hline 18. & Leading Affluence & 2.30 & 0.30 & No & No & Real Estate \\
\hline 19. & Tencent Holdings & 2.20 & 0.28 & No & Yes & Comunications \\
\hline 20. & Bohai International Capital & 2.00 & 0.26 & No & No & Iron and Steel \\
\hline 21. & China Energy Reserve and Chemicals Group Overseas & 2.00 & 0.26 & No & No & Oil \\
\hline 22. & Hong Kong Science and Technology Parks & 1.71 & 0.22 & Yes & No & Real Estate \\
\hline 23. & Value Success International & 1.55 & 0.20 & No & No & Finance \\
\hline 24. & Chueng Kong Finance (MTN) & 1.50 & 0.19 & No & No & Finance \\
\hline 25. & Airport Authority Hong Kong & 1.45 & 0.19 & Yes & No & Transportation \\
\hline 26. & Hysan (MTN) & 1.40 & 0.18 & No & Yes & Real Estate \\
\hline 27. & Wharf Finance (No. 1) & 1.33 & 0.17 & No & No & Finance \\
\hline 28. & Nan Fung Treasury & 1.31 & 0.17 & No & No & Finance \\
\hline 29. & Henderson Land MTN & 1.19 & 0.15 & No & Yes & Finance \\
\hline 30. & Cheung Kong Bond Securities (02) & 1.00 & 0.13 & No & No & Finance \\
\hline Tot & Top 30 Nonbank LCY Corporate Issuers & 136.26 & 17.57 & & & \\
\hline Tot & LCY Corporate Bonds & 767.48 & 98.95 & & & \\
\hline Top & 30 as $\%$ of Total LCY Corporate Bonds & $17.8 \%$ & $17.8 \%$ & & & \\
\hline
\end{tabular}

$\mathrm{HKD}=$ Hong Kong dollar, LCY = local currency, USD = United States dollar.

Notes:

1. Data as of end-December 2016.

2. State-owned firms are defined as those in which the government has more than a $50 \%$ ownership stake.

Source: AsianBondsOnline calculations based on Hong Kong Monetary Authority data. 


\section{Indonesia}

Indonesia's local currency (LCY) bond market reached a size of IDR2,190 trillion (USD163 billion) at the end of the fourth quarter (Q4) of 2016, up 1.7\% quarter-on-quarter and 25.1\% year-on-year. Growth stemmed from increases in the stock of central government bonds and corporate bonds.

Table 1: Size and Composition of the Local Currency Bond Market in Indonesia

\begin{tabular}{|c|c|c|c|c|c|c|c|c|c|c|}
\hline & \multicolumn{6}{|c|}{ Outstanding Amount (billion) } & \multicolumn{4}{|c|}{ Growth Rate (\%) } \\
\hline & \multicolumn{2}{|c|}{ Q4 2015} & \multicolumn{2}{|c|}{ Q3 2016} & \multicolumn{2}{|c|}{ Q4 2016} & \multicolumn{2}{|c|}{ Q4 2015} & \multicolumn{2}{|c|}{ Q4 2016} \\
\hline & IDR & USD & IDR & USD & IDR & USD & $q-o-q$ & $y-0-y$ & $q-o-q$ & $y-0-y$ \\
\hline Total & $1,750,306$ & 127 & $2,153,035$ & 165 & $2,190,326$ & 163 & 3.4 & 14.4 & 1.7 & 25.1 \\
\hline Government & $1,500,426$ & 109 & $1,866,325$ & 143 & $1,878,648$ & 139 & 4.0 & 14.8 & 0.7 & 25.2 \\
\hline Central Govt. Bonds & $1,461,846$ & 106 & $1,749,384$ & 134 & $1,773,279$ & 132 & 5.0 & 20.8 & 1.4 & 21.3 \\
\hline of which: Sukuk & 159,236 & 12 & 239,868 & 18 & 245,708 & 18 & 5.9 & 43.8 & 2.4 & 54.3 \\
\hline Central Bank Bills & 38,580 & 3 & 116,941 & 9 & 105,369 & 8 & $(23.4)$ & $(60.2)$ & $(9.9)$ & 173.1 \\
\hline of which: Sukuk & 6,280 & 0.5 & 9,442 & 0.7 & 10,788 & 0.8 & (18.7) & (22.8) & 14.3 & 71.8 \\
\hline Corporate & 249,880 & 18 & 286,710 & 22 & 311,679 & 23 & 0.1 & 12.1 & 8.7 & 24.7 \\
\hline of which: Sukuk & 9,802 & 0.7 & 10,744 & 0.8 & 11,578 & 0.9 & 18.3 & 38.0 & 7.8 & 18.1 \\
\hline
\end{tabular}

()$=$ negative, IDR = Indonesian rupiah, $L C Y=$ local currency, $q-o-q=$ quarter-on-quarter, $Q 3=$ third quarter, $Q 4=$ fourth quarter, USD = United States dollar, $y-0-y=y e a r-o n-y e a r$. Notes:

1. Calculated using data from national sources.

2. Bloomberg LP end-of-period LCY-USD rates are used.

3. Growth rates are calculated from an LCY base and do not include currency effects.

4. The total stock of nontradable bonds as of end-December stood at IDR238.2 trillion.

Sources: Bank Indonesia; Directorate General of Budget Financing and Risk Management, Ministry of Finance; Indonesia Stock Exchange; Otoritas Jasa Keuangan; and Bloomberg LP.

In Q4 2016, new corporate debt issues totaled IDR38.9 trillion, up on both a quarter-on-quarter and year-on-year basis. A total of $\mathbf{2 7}$ corporate entities locked in lower borrowing costs by raising funds from the debt market in Q4 2016. As in past quarters, banking and financial institutions dominated the list of new corporate debt issuers in Q4 2016.

Table 2: Notable Local Currency Corporate Bond Issuance in the Fourth Quarter of 2016

\begin{tabular}{|c|c|c|c|c|c|}
\hline Corporate Issuers & $\begin{array}{c}\text { Coupon Rate } \\
(\%)\end{array}$ & $\begin{array}{l}\text { Issued Amount } \\
\text { (IDR billion) }\end{array}$ & Corporate Issuers & $\begin{array}{c}\text { Coupon Rate } \\
(\%)\end{array}$ & $\begin{array}{l}\text { Issued Amount } \\
\text { (IDR billion) }\end{array}$ \\
\hline Bank Mandiri & & & Angkasa Pura I & & \\
\hline 5-year bond & 7.95 & 1,100 & 5-year bond & 8.10 & 622 \\
\hline 7-year bond & 8.50 & 1,500 & 5-year sukuk ijarah & 8.10 & 268 \\
\hline 10-year bond & 8.65 & 2,400 & 7-year bond & 8.40 & 389 \\
\hline Sarana Multi Infrastruktur & & & 7-year sukuk ijarah & 8.40 & 55 \\
\hline 3-year bond & 7.85 & 2,298 & 10-year bond & 8.55 & 1,489 \\
\hline 5-year bond & 8.20 & 1,328 & 10-year sukuk ijarah & 8.55 & 177 \\
\hline 10-year bond & 8.65 & 700 & Indonesia Eximbank & & \\
\hline 15-year bond & 8.90 & 674 & 370-day bond & 7.15 & 672 \\
\hline Bank Rakyat Indonesia & & & 3-year bond & 7.85 & 540 \\
\hline 370-day bond & 7.25 & 616 & 5-year bond & 8.20 & 282 \\
\hline 3-year bond & 8.00 & 964 & 7-year bond & 8.50 & 1,038 \\
\hline 5-year bond & 8.20 & 193 & & & \\
\hline 7-year bond & 8.65 & 477 & & & \\
\hline 10-year bond & 8.90 & 2,350 & & & \\
\hline
\end{tabular}

IDR = Indonesian rupiah.

Note: Sukuk ljarah refers to Islamic bonds backed by lease agreements.

Source: Indonesia Stock Exchange. 
At the end of December, the top $30 \mathrm{LCY}$ corporate bond issuers in Indonesia had an aggregate bond stock of IDR228.0 trillion, accounting for $73.2 \%$ of the total LCY corporate bond market. Leading the list was Indonesia Eximbank with outstanding bonds of IDR31.4 trillion at the end of December. Climbing to the second spot was Bank Rakyat Indonesia. Both Indonesia Eximbank and Bank Rakyat Indonesia raised additional funds from the LCY debt market in Q4 2016. Telecommunications firm Indosat had the third largest stock of outstanding bonds at the end of December.

Table 3: Top 30 Issuers of Local Currency Corporate Bonds in Indonesia

\begin{tabular}{|c|c|c|c|c|c|c|}
\hline & & Outstanc & Amount & & & \\
\hline & Issuers & $\begin{array}{l}\text { LCY Bonds } \\
\text { (IDR billion) }\end{array}$ & $\begin{array}{l}\text { LCY Bonds } \\
\text { (USD billion) }\end{array}$ & $\begin{array}{l}\text { State- } \\
\text { Owned }\end{array}$ & $\begin{array}{l}\text { Listed } \\
\text { Company }\end{array}$ & Type of Industry \\
\hline 1. & Indonesia Eximbank & 31,402 & 2.33 & Yes & No & Banking \\
\hline 2. & Bank Rakyat Indonesia & 15,945 & 1.18 & Yes & Yes & Banking \\
\hline 3. & Indosat & 13,721 & 1.02 & No & Yes & Telecommunications \\
\hline 4. & Bank Tabungan Negara & 12,950 & 0.96 & Yes & Yes & Banking \\
\hline 5. & PLN & 11,733 & 0.87 & Yes & No & Energy \\
\hline 6. & Bank Pan Indonesia & 9,685 & 0.72 & No & Yes & Banking \\
\hline 7. & Astra Sedaya Finance & 9,475 & 0.70 & No & No & Finance \\
\hline 8. & Telekomunikasi Indonesia & 8,995 & 0.67 & Yes & Yes & Telecommunications \\
\hline 9. & Federal International Finance & 8,893 & 0.66 & No & No & Finance \\
\hline 10. & Adira Dinamika Multifinance & 8,638 & 0.64 & No & Yes & Finance \\
\hline 11. & Bank Internasional Indonesia & 7,320 & 0.54 & No & Yes & Banking \\
\hline 12. & Perum Pegadaian & 6,792 & 0.50 & Yes & No & Finance \\
\hline 13. & Sarana Multigriya Finansial & 6,530 & 0.48 & Yes & No & Finance \\
\hline 14. & Medco-Energi International & 6,274 & 0.47 & No & Yes & Petroleum and Natural Gas \\
\hline 15. & Bank CIMB Niaga & 6,230 & 0.46 & No & Yes & Banking \\
\hline 16. & Sarana Multi Infrastruktur & 6,000 & 0.45 & Yes & No & Finance \\
\hline 17. & Bank Permata & 5,810 & 0.43 & No & Yes & Banking \\
\hline 18. & Waskita Karya & 5,575 & 0.41 & Yes & Yes & Building Construction \\
\hline 19. & Bank Mandiri & 5,000 & 0.37 & Yes & Yes & Banking \\
\hline 20. & Bank OCBC NISP & 4,785 & 0.36 & No & Yes & Banking \\
\hline 21. & Jasa Marga & 4,500 & 0.33 & Yes & Yes & Toll Roads, Airports, and Harbors \\
\hline 22. & Toyota Astra Financial Services & 4,421 & 0.33 & No & No & Finance \\
\hline 23. & Indofood Sukses Makmur & 4,000 & 0.30 & No & Yes & Food and Beverages \\
\hline 24. & Agung Podomoro Land & 3,700 & 0.27 & No & Yes & Property and Real Estate \\
\hline 25. & Permodalan Nasional Madani & 3,433 & 0.25 & Yes & No & Finance \\
\hline 26. & Mandiri Tunas Finance & 3,325 & 0.25 & No & No & Finance \\
\hline 27. & Bumi Serpong Damai & 3,315 & 0.25 & No & Yes & Property and Real Estate \\
\hline 28. & Maybank Indonesia Finance & 3,225 & 0.24 & No & No & Finance \\
\hline 29. & Bank UOB Indonesia & 3,200 & 0.24 & No & No & Banking \\
\hline 30. & Surya Artha Nusantara Finance & 3,150 & 0.23 & No & No & Finance \\
\hline Tot & Top 30 LCY Corporate Issuers & 228,022 & 16.92 & & & \\
\hline Tot & LCY Corporate Bonds & 311,679 & 23.13 & & & \\
\hline Top & 30 as $\%$ of Total LCY Corporate Bonds & $73.2 \%$ & $73.2 \%$ & & & \\
\hline
\end{tabular}

IDR = Indonesian rupiah, LCY = local currency, USD = United States dollar.

Notes:

1. Data as of end-December 2016.

2. State-owned firms are defined as those in which the government has more than a $50 \%$ ownership stake.

Source: AsianBondsOnline calculations based on Indonesia Stock Exchange data. 


\section{Republic of Korea}

The Republic of Korea's local currency (LCY) bond market declined $0.5 \%$ quarter-on-quarter (q-o-q) to KRW2,066 trillion (USD1,714 billion) at the end of the fourth quarter (Q4) of 2016. The decline was most notable in the government bond sector, which fell 1.0\% q-o-q to KRW848 trillion, largely driven by a decrease in central bank bonds outstanding. Corporate bonds also declined 0.2\% q-o-q to KRW1,219 trillion. On a year-on-year basis, the Republic of Korea's LCY bond market grew 2.3\% in Q4 2016.

Table 1: Size and Composition of the Local Currency Bond Market in the Republic of Korea

\begin{tabular}{|c|c|c|c|c|c|c|c|c|c|c|}
\hline & \multicolumn{6}{|c|}{ Outstanding Amount (billion) } & \multicolumn{4}{|c|}{ Growth Rate (\%) } \\
\hline & \multicolumn{2}{|c|}{ Q4 2015} & \multicolumn{2}{|c|}{ Q3 2016} & \multicolumn{2}{|c|}{ Q4 2016} & \multicolumn{2}{|c|}{ Q4 2015} & \multicolumn{2}{|c|}{ Q4 2016} \\
\hline & KRW & USD & KRW & USD & KRW & USD & $q-0-q$ & $y-0-y$ & $q-o-q$ & $y-0-y$ \\
\hline Total & $2,020,522$ & 1,720 & $2,076,602$ & 1,886 & $2,066,453$ & 1,714 & 1.1 & 8.8 & $(0.5)$ & 2.3 \\
\hline Government & 821,993 & 700 & 855,763 & 777 & 847,537 & 703 & 1.0 & 7.4 & $(1.0)$ & 3.1 \\
\hline Central Government Bonds & 485,104 & 413 & 517,267 & 470 & 516,908 & 429 & $(9.6)$ & 10.7 & $(0.1)$ & 6.6 \\
\hline Central Bank Bonds & 180,930 & 154 & 179,680 & 163 & 168,390 & 140 & $(2.9)$ & 1.6 & $(6.3)$ & $(6.9)$ \\
\hline Others & 155,959 & 133 & 158,816 & 144 & 162,239 & 135 & 72.6 & 4.8 & 2.2 & 4.0 \\
\hline Corporate & $1,198,529$ & 1,020 & $1,220,839$ & 1,109 & $1,218,916$ & 1,011 & 1.1 & 9.7 & $(0.2)$ & 1.7 \\
\hline
\end{tabular}

$($ ) = negative, KRW = Korean won, LCY = local currency, q-o-q = quarter-on-quarter, Q3 = third quarter, Q4 = fourth quarter, USD = United States dollar, $y$-o-y = year-on-year. Notes:

1. Calculated using data from national sources.

2. Bloomberg LP end-of-period LCY-USD rates are used.

3. Growth rates are calculated from an LCY base and do not include currency effects.

4. "Others" comprise Korea Development Bank bonds, National Housing bonds, and Seoul Metro bonds.

5. Corporate bonds include equity-linked securities and derivatives-linked securities.

Sources: The Bank of Korea and EDAILY BondWeb.

Corporate bond issuance in the Republic of Korea rose to KRW99,354 billion in Q4 2016 from KRW81,513 billion in the third quarter of 2016.

Table 2: Notable LCY Corporate Bond Issuance in the Fourth Quarter of 2016

\begin{tabular}{|c|c|c|c|c|c|}
\hline Corporate Issuers & $\begin{array}{c}\text { Coupon Rate } \\
(\%)\end{array}$ & $\begin{array}{l}\text { Issued Amount } \\
\text { (KRW billion) }\end{array}$ & Corporate Issuers & $\begin{array}{c}\text { Coupon Rate } \\
(\%)\end{array}$ & $\begin{array}{l}\text { Issued Amount } \\
\text { (KRW billion) }\end{array}$ \\
\hline Industrial Bank of Korea & & & \multicolumn{3}{|l|}{ Woori Bank } \\
\hline 1.5 -year bond & 1.47 & 270 & 2-year bond & 1.62 & 500 \\
\hline 1.5 -year bond & 1.50 & 370 & 2-year bond & 1.81 & 90 \\
\hline 20-year bond & 2.05 & 50 & 2-year bond & 1.84 & 100 \\
\hline 20-year bond & 2.07 & 30 & 2-year bond & 1.93 & 200 \\
\hline 20-year bond & 2.20 & 70 & 3-year bond & 1.65 & 150 \\
\hline 20-year bond & 2.40 & 80 & \multicolumn{3}{|c|}{ Daewoo Shipbuilding and Marine Engineering } \\
\hline 20-year bond & 2.50 & 50 & 30-year bond & 3.00 & 1,000 \\
\hline 20-year bond & 2.81 & 300 & \multicolumn{3}{|c|}{ National Federation of Fisheries Cooperatives } \\
\hline perpetual bond & 2.88 & 50 & 1.5 -year bond & 1.79 & 60 \\
\hline \multirow[t]{3}{*}{ perpetual bond } & 3.27 & 250 & 5-year bond & 1.87 & 550 \\
\hline & & & 7-year bond & 1.94 & 100 \\
\hline & & & 10-year bond & 2.06 & 150 \\
\hline
\end{tabular}

$\mathrm{KRW}=$ Korean won.

Source: Based on data from Bloomberg LP. 
LCY bonds outstanding among the top 30 corporate bond issuers in the Republic of Korea reached KRW787,910 billion at the end of December, representing $64.6 \%$ of total corporate bonds outstanding.

Table 3: Top 30 Issuers of Local Currency Corporate Bonds in the Republic of Korea

\begin{tabular}{|c|c|c|c|c|c|c|c|}
\hline & & Outstand & Amount & & & on & \\
\hline & Issuers & LCY Bonds & LCY Bonds & Owned & & & Type of Industry \\
\hline & & (KRW billion) & (USD billion) & & KOSPI & KOSDAQ & \\
\hline 1. & Korea Housing Finance Corporation & 105,761 & 87.7 & Yes & No & No & Housing Finance \\
\hline 2. & NH Investment \& Securities & 62,888 & 52.2 & Yes & Yes & No & Securities \\
\hline 3. & Mirae Asset Daewoo Co. & 55,951 & 46.4 & No & Yes & No & Securities \\
\hline 4. & Korea Investment and Securities & 51,579 & 42.8 & No & No & No & Securities \\
\hline 5. & Korea Land \& Housing Corporation & 47,324 & 39.2 & Yes & No & No & Real Estate \\
\hline 6. & Industrial Bank of Korea & 39,871 & 33.1 & Yes & Yes & No & Banking \\
\hline 7. & Mirae Asset Securities & 39,369 & 32.6 & No & Yes & No & Securities \\
\hline 8. & Hana Financial Investment & 36,898 & 30.6 & No & No & No & Securities \\
\hline 9. & Korea Deposit Insurance Corporation & 29,290 & 24.3 & Yes & No & No & Insurance \\
\hline 10. & KB Securities & 25,551 & 21.2 & No & No & No & Securities \\
\hline 11. & Korea Electric Power Corporation & 22,470 & 18.6 & Yes & Yes & No & $\begin{array}{c}\text { Electricity, Energy, } \\
\text { and Power }\end{array}$ \\
\hline 12. & Korea Highway & 20,910 & 17.3 & Yes & No & No & Infrastructure \\
\hline 13. & Samsung Securities & 19,517 & 16.2 & No & Yes & No & Securities \\
\hline 14. & Shinhan Bank & 18,952 & 15.7 & No & No & No & Banking \\
\hline 15. & Korea Rail Network Authority & 18,600 & 15.4 & Yes & No & No & $\begin{array}{c}\text { Transport } \\
\text { Infrastructure }\end{array}$ \\
\hline 16. & Woori Bank & 17,625 & 14.6 & Yes & Yes & No & Banking \\
\hline 17. & Kookmin Bank & 17,346 & 14.4 & No & No & No & Banking \\
\hline 18. & Daishin Securities & 16,716 & 13.9 & No & Yes & No & Securities \\
\hline 19. & NongHyup Bank & 16,100 & 13.4 & Yes & No & No & Banking \\
\hline 20. & Korea Gas Corporation & 14,469 & 12.0 & Yes & Yes & No & Gas Utility \\
\hline 21. & The Export-Import Bank of Korea & 13,160 & 10.9 & Yes & No & No & Banking \\
\hline 22. & Small \& Medium Business Corporation & 12,500 & 10.4 & Yes & No & No & SME Development \\
\hline 23. & Korea Student Aid Foundation & 11,660 & 9.7 & Yes & No & No & Student Loan \\
\hline 24. & Standard Charted Bank Korea & 11,110 & 9.2 & No & No & No & Banking \\
\hline 25. & Shinhan Card & 10,746 & 8.9 & No & No & No & Credit Card \\
\hline 26. & Korea Water Resources Corporation & 10,545 & 8.7 & Yes & No & No & Water \\
\hline 27. & Hyundai Capital Services & 10,494 & 8.7 & No & No & No & Consumer Finance \\
\hline 28. & NongHyup & 10,440 & 8.7 & Yes & No & No & Diversified \\
\hline 29. & KEB Hana Bank & 10,270 & 8.5 & No & No & No & Banking \\
\hline 30. & Korea Railroad Corporation & 9,800 & 8.1 & Yes & No & No & $\begin{array}{c}\text { Transport } \\
\text { Infrastructure }\end{array}$ \\
\hline Tot & I Top 30 LCY Corporate Issuers & 787,910 & 653 & & & & \\
\hline Tot & LCY Corporate Bonds & $1,218,916$ & 1,011 & & & & \\
\hline Top & 30 as $\%$ of Total LCY Corporate Bonds & $64.6 \%$ & $64.6 \%$ & & & & \\
\hline
\end{tabular}

KOSDAQ = Korean Securities Dealer Automated Quotations, KOSPI = Korea Composite Stock Price Index, KRW = Korean won, LCY $=$ local currency, SME $=$ small and medium-sized enterprises, USD = United States dollar.

Notes:

1. Data as of end-December 2016.

2. State-owned firms are defined as those in which the government has more than a $50 \%$ ownership stake.

3. Corporate bonds include equity-linked securities and derivatives-linked securities.

4. Data do not reflect the acquisition of Mirae Asset Securities by Mirae Asset Daewoo in January 2017.

Source: AsianBondsOnline calculations based on Bloomberg LP and EDAILY BondWeb data. 


\section{Malaysia}

Total local currency (LCY) bonds outstanding in Malaysia stood at MYR1,167 billion (USD260 billion) at the end of the fourth quarter (Q4) of 2016, a decrease of $0.1 \%$ quarter-on-quarter (q-o-q) but an increase of $4.3 \%$ year-on-year ( $y-0-y)$. The q-o-q contraction was due to corporate bonds falling $0.5 \% \mathrm{q}-0-\mathrm{q}$, offsetting the $0.3 \%$ q-o-q increase in government bonds. Government and corporate bonds outstanding grew 3.6\% y-o-y and 5.2\% y-o-y, respectively. Sukuk (Islamic bonds) comprised 41.7\% of total LCY government bonds outstanding and $73.9 \%$ of total LCY corporate bonds outstanding at the end of December.

Table 1: Size and Composition of the Local Currency Bond Market in Malaysia

\begin{tabular}{|c|c|c|c|c|c|c|c|c|c|c|}
\hline & \multicolumn{6}{|c|}{ Outstanding Amount (billion) } & \multicolumn{4}{|c|}{ Growth Rate (\%) } \\
\hline & \multicolumn{2}{|c|}{ Q4 2015} & \multicolumn{2}{|c|}{ Q3 2016} & \multicolumn{2}{|c|}{ Q4 2016} & \multicolumn{2}{|c|}{ Q4 2015} & \multicolumn{2}{|c|}{ Q4 2016} \\
\hline & MYR & USD & MYR & USD & MYR & USD & $q-o-q$ & $y-0-y$ & $q-0-q$ & $y-0-y$ \\
\hline Total & 1,119 & 261 & 1,168 & 282 & 1,167 & 260 & 4.0 & 1.4 & $(0.1)$ & 4.3 \\
\hline Government & 612 & 142 & 632 & 153 & 634 & 141 & 1.6 & $(5.5)$ & 0.3 & 3.6 \\
\hline Central Government Bonds & 559 & 130 & 592 & 143 & 596 & 133 & 1.9 & 7.6 & 0.7 & 6.7 \\
\hline of which: sukuk & 216 & 50 & 236 & 57 & 236 & 53 & 4.8 & 15.0 & 0.0 & 9.4 \\
\hline Central Bank Bills & 25 & 6 & 11 & 3 & 9 & 2 & $(1.2)$ & (77.1) & $(18.6)$ & $(64.3)$ \\
\hline of which: sukuk & 1 & 0.1 & 0 & 0 & 0 & 0 & $(70.6)$ & $(98.8)$ & - & $(100.0)$ \\
\hline Sukuk Perumahan Kerajaan & 28 & 7 & 28 & 7 & 28 & 6 & 0.0 & 39.2 & 0.0 & 0.0 \\
\hline Corporate & 507 & 118 & 537 & 130 & 534 & 119 & 7.1 & 11.1 & $(0.5)$ & 5.2 \\
\hline of which: sukuk & 361 & 84 & 393 & 95 & 395 & 88 & 6.0 & 11.7 & 0.3 & 9.3 \\
\hline
\end{tabular}

()$=$ negative, - = not applicable, LCY = local currency, MYR = Malaysian ringgit, q-o-q = quarter-on-quarter, Q3 = third quarter, Q4 = fourth quarter, USD = United States dollar, $y-0-y=$ year-on-year.

Notes:

1. Calculated using data from national sources.

2. Bloomberg LP end-of-period LCY-USD rate is used.

3. Growth rates are calculated from an LCY base and do not include currency effects.

4. Sukuk Perumahan Kerajaan are Islamic bonds issued by the government to refinance funding for housing loans to government employees and to extend new housing loans.

Sources: Bank Negara Malaysia Fully Automated System for Issuing/Tendering and Bloomberg LP.

Corporate bond issuance fell to MYR30.3 billion in Q4 2016 from MYR39.9 billion in Q3 2016.

Table 2: Notable Local Currency Corporate Bond Issuance in the Fourth Quarter of 2016

\begin{tabular}{ccc} 
Corporate Issuers & $\begin{array}{c}\text { Coupon Rate } \\
(\%)\end{array}$ & $\begin{array}{c}\text { Issued Amount } \\
\text { (MYR million) }\end{array}$ \\
\hline Danainfra Nasional & 3.92 & 400 \\
7-year Islamic MTN & 4.09 & 600 \\
10-year Islamic MTN & 4.48 & 700 \\
15-year Islamic MTN & 4.65 & 800 \\
20-year Islamic MTN & 4.78 & 1,000 \\
25-year Islamic MTN & 4.95 & 1,000 \\
30-year Islamic MTN & & \\
\hline Maxis Broadband & 4.70 & 500 \\
4-year Islamic MTN & 5.00 & 2,450 \\
6-year Islamic MTN & & \\
\hline
\end{tabular}

MTN = medium-term note, MYR = Malaysian ringgit.

Source: Bank Negara Malaysia Bond Info Hub. 
The amount outstanding of the top 30 corporate bonds issuers summed to MYR292.9 billion at the end of December, comprising $54.9 \%$ of the total LCY corporate bonds outstanding. The finance industry was the sector with the largest share of LCY corporate bonds outstanding among the top 30 corporate issuers, accounting for a cumulative MYR128.2 billion at the end of December.

Table 3: Top 30 Issuers of Local Currency Corporate Bonds in Malaysia

\begin{tabular}{|c|c|c|c|c|c|c|}
\hline & & Outstand & g Amount & & & \\
\hline & Issuers & $\begin{array}{l}\text { LCY Bonds } \\
\text { (MYR billion) }\end{array}$ & $\begin{array}{l}\text { LCY Bonds } \\
\text { (USD billion) }\end{array}$ & Owned & Company & Type of Industry \\
\hline 1. & Project Lebuhraya Usahasama & 30.6 & 6.8 & No & No & $\begin{array}{l}\text { Transport, Storage, } \\
\text { and Communications }\end{array}$ \\
\hline 2. & Danainfra Nasional & 29.7 & 6.6 & Yes & No & Finance \\
\hline 3. & Cagamas & 25.6 & 5.7 & Yes & No & Finance \\
\hline 4. & Prasarana & 18.7 & 4.2 & Yes & No & $\begin{array}{l}\text { Transport, Storage, } \\
\text { and Communications }\end{array}$ \\
\hline 5. & Khazanah & 18.0 & 4.0 & Yes & No & Finance \\
\hline 6. & Perbadanan Tabung Pendidikan Tinggi Nasional & 14.5 & 3.2 & Yes & No & Finance \\
\hline 7. & Maybank & 14.0 & 3.1 & No & Yes & Banking \\
\hline 8. & Pengurusan Air & 14.0 & 3.1 & Yes & No & Energy, Gas, and Water \\
\hline 9. & Sarawak Energy & 9.5 & 2.1 & Yes & No & Energy, Gas, and Water \\
\hline 10. & CIMB Group Holdings & 9.5 & 2.1 & Yes & No & Finance \\
\hline 11. & Jimah East Power & 9.0 & 2.0 & Yes & No & Energy, Gas, and Water \\
\hline 12. & Public Bank & 7.4 & 1.6 & No & No & Banking \\
\hline 13. & Sarawak Hidro & 6.5 & 1.5 & Yes & No & Energy, Gas, and Water \\
\hline 14. & Aman Sukuk & 6.1 & 1.4 & Yes & No & Construction \\
\hline 15. & Rantau Abang Capital & 6.0 & 1.3 & Yes & No & Finance \\
\hline 16. & Bank Pembangunan Malaysia & 5.9 & 1.3 & Yes & No & Banking \\
\hline 17. & CIMB Group Holdings & 5.4 & 1.2 & Yes & No & Finance \\
\hline 18. & Turus Pesawat & 5.3 & 1.2 & Yes & No & $\begin{array}{l}\text { Transport, Storage, } \\
\text { and Communications }\end{array}$ \\
\hline 19. & RHB Bank & 5.2 & 1.1 & No & No & Banking \\
\hline 20. & Putrajaya Holdings & 5.1 & 1.1 & Yes & No & Property and Real Estate \\
\hline 21. & 1Malaysia Development & 5.0 & 1.1 & Yes & No & Finance \\
\hline 22. & Celcom Networks & 5.0 & 1.1 & No & No & $\begin{array}{l}\text { Transport, Storage, } \\
\text { and Communications }\end{array}$ \\
\hline 23. & Danga Capital & 5.0 & 1.1 & Yes & No & Finance \\
\hline 24. & ValueCap & 5.0 & 1.1 & Yes & No & Finance \\
\hline 25. & YTL Power International & 4.8 & 1.1 & No & Yes & Energy, Gas, and Water \\
\hline 26. & GOVCO Holdings & 4.6 & 1.0 & Yes & No & Finance \\
\hline 27. & Jambatan Kedua & 4.6 & 1.0 & Yes & No & $\begin{array}{l}\text { Transport, Storage, } \\
\text { and Communications }\end{array}$ \\
\hline 28. & Manjung Island Energy & 4.5 & 1.0 & No & No & Energy, Gas, and Water \\
\hline 29. & Malakoff Power & 4.3 & 1.0 & No & No & Energy, Gas, and Water \\
\hline 30. & BGSM Management & 4.3 & 1.0 & No & No & $\begin{array}{l}\text { Transport, Storage, } \\
\text { and Communications }\end{array}$ \\
\hline Tota & I Top 30 LCY Corporate Issuers & 292.9 & 65.3 & & & \\
\hline Tota & I LCY Corporate Bonds & 533.7 & 119.0 & & & \\
\hline Top & 30 as $\%$ of Total LCY Corporate Bonds & $54.9 \%$ & $54.9 \%$ & & & \\
\hline
\end{tabular}

Notes:

1. Data as of end-December 2016.

2. State-owned firms are defined as those in which the government has more than a $50 \%$ ownership stake.

Source: AsianBondsOnline calculations based on Bank Negara Malaysia Fully Automated System for Issuing/Tendering data. 


\section{Philippines}

The Philippines' local currency (LCY) bond market grew 1.4\% quarter-on-quarter (q-o-q) and 2.3\% year-onyear ( $y-0-y)$ in the fourth quarter (Q4) of 2016, amounting to PHP4,869 billion (USD98 billion) at the end of December 2016. Government bonds outstanding reached PHP3,978 billion, up 0.6\% q-o-q and 0.8\% y-o-y, primarily driven by growth in Treasury bonds. The corporate bond market registered faster growth than the government bond market, expanding 5.5\% q-o-q and 9.5\% y-o-y.

Table 1: Size and Composition of the Local Currency Bond Market in the Philippines

\begin{tabular}{|c|c|c|c|c|c|c|c|c|c|c|}
\hline & \multicolumn{6}{|c|}{ Outstanding Amount (billion) } & \multicolumn{4}{|c|}{ Growth Rate (\%) } \\
\hline & \multicolumn{2}{|c|}{ Q4 2015} & \multicolumn{2}{|c|}{ Q3 2016} & \multicolumn{2}{|c|}{ Q4 2016} & \multicolumn{2}{|c|}{ Q4 2015} & \multicolumn{2}{|c|}{ Q4 2016} \\
\hline & PHP & USD & PHP & USD & PHP & USD & $q-o-q$ & $y-0-y$ & $q-o-q$ & $y-0-y$ \\
\hline Total & 4,760 & 101 & 4,800 & 99 & 4,869 & 98 & 0.8 & 2.1 & 1.4 & 2.3 \\
\hline Government & 3,946 & 84 & 3,955 & 82 & 3,978 & 80 & 0.2 & 1.3 & 0.6 & 0.8 \\
\hline Treasury Bills & 264 & 6 & 293 & 6 & 288 & 6 & $(6.4)$ & $(6.1)$ & $(1.7)$ & 8.9 \\
\hline Treasury Bonds & 3,596 & 77 & 3,587 & 74 & 3,621 & 73 & 0.5 & 2.5 & 1.0 & 0.7 \\
\hline Others & 86 & 2 & 76 & 2 & 69 & 1 & 7.5 & $(16.8)$ & $(8.4)$ & (19.5) \\
\hline Corporate & 814 & 17 & 845 & 17 & 891 & 18 & 3.8 & 6.0 & 5.5 & 9.5 \\
\hline
\end{tabular}

()$=$ negative, $\mathrm{LCY}=$ local currency, $\mathrm{PHP}=$ Philippine peso, $\mathrm{q}-\mathrm{o}-\mathrm{q}=$ quarter-on-quarter, $\mathrm{Q} 3=$ third quarter, $\mathrm{Q} 4=$ fourth quarter, USD $=$ United States dollar, $y$-o- $y=y e a r-o n-y e a r$. Notes:

1. Calculated using data from national sources.

2. Bloomberg end-of-period LCY-USD rates are used.

3. Growth rates are calculated from an LCY base and do not include currency effects.

4. "Others" comprise bonds issued by government agencies, entities, and corporations for which repayment is guaranteed by the Government of the Philippines. This includes bonds issued by Power Sector Assets and Liabilities Management (PSALM) and the National Food Authority, among others.

5. Peso Global Bonds (PHP-denominated bonds payable in US dollars) are not included.

Sources: Bloomberg LP and Bureau of the Treasury.

Total LCY corporate bond issuance reached PHP71.9 billion in Q4 2016, an increase of 60.3\% q-o-q and $147.9 \%$ y-o-y.

Table 2: Notable Local Currency Corporate Bond Issuance in the Fourth Quarter of 2016

\begin{tabular}{lcc} 
Corporate Issuers & $\begin{array}{c}\text { Coupon Rate } \\
(\%)\end{array}$ & $\begin{array}{c}\text { Issued Amount } \\
\text { (PHP billion) }\end{array}$ \\
$\begin{array}{l}\text { SM Investments } \\
\text { 7-year bond }\end{array}$ & 5.159 & 20.00 \\
\hline Petron & & \\
5-year bond & 4.003 & 9.75 \\
7-year bond & 4.522 & 5.25 \\
\hline Ayala Land & & 3.00 \\
3-year bond & 3.000 & 7.00 \\
7-year bond & 3.892 & \\
\hline China Bank & & 9.59 \\
6-year bond & 3.250 & \\
\hline
\end{tabular}

$\mathrm{PHP}=$ Philippine peso.

Source: Bloomberg LP. 
The outstanding LCY bonds of the top 30 corporate issuers at the end of December 2016 summed to PHP774.9 billion, which comprised $86.9 \%$ of the total LCY corporate bond market. The bulk of the LCY bond stock in the top 30 list emanates from the banking industry, followed by property and holding firms. Ayala Land remained the largest corporate bond issuer in the Philippines in 2016.

Table 3: Top 30 Issuers of Local Currency Corporate Bonds in the Philippines

\begin{tabular}{|c|c|c|c|c|c|c|}
\hline \multirow{2}{*}{\multicolumn{2}{|c|}{ Issuers }} & \multicolumn{2}{|c|}{ Outstanding Amount } & \multirow[b]{2}{*}{$\begin{array}{l}\text { State- } \\
\text { Owned }\end{array}$} & \multirow[b]{2}{*}{ Listed Company } & \multirow[b]{2}{*}{ Type of Industry } \\
\hline & & $\begin{array}{l}\text { LCY Bonds } \\
\text { (PHP billion) }\end{array}$ & $\begin{array}{l}\text { LCY Bonds } \\
\text { (USD billion) }\end{array}$ & & & \\
\hline 1. & Ayala Land & 80.3 & 1.6 & No & Yes & Property \\
\hline 2. & Metrobank & 55.4 & 1.1 & No & Yes & Banking \\
\hline 3. & SM Prime & 55.0 & 1.1 & No & Yes & Property \\
\hline 4. & SM Investments & 47.3 & 1.0 & No & Yes & Holding Firms \\
\hline 5. & Ayala Corporation & 40.0 & 0.8 & No & Yes & Holding Firms \\
\hline 6. & San Miguel Brewery & 37.8 & 0.8 & No & No & Brewery \\
\hline 7. & BDO Unibank & 37.5 & 0.8 & No & Yes & Banking \\
\hline 8. & Philippine National Bank & 34.5 & 0.7 & No & Yes & Banking \\
\hline 9. & JG Summit & 30.0 & 0.6 & No & Yes & Holding Firms \\
\hline 10. & Filinvest Land & 29.0 & 0.6 & No & Yes & Property \\
\hline 11. & Aboitiz Equity Ventures & 24.0 & 0.5 & No & Yes & Holding Firms \\
\hline 12. & Meralco & 23.5 & 0.5 & No & Yes & Electricity, Energy, and Power \\
\hline 13. & Security Bank & 23.0 & 0.5 & No & Yes & Banking \\
\hline 14. & Rizal Commercial Banking Corporation & 22.1 & 0.4 & No & Yes & Banking \\
\hline 15. & GT Capital & 22.0 & 0.4 & No & Yes & Holding Firms \\
\hline 16. & Petron & 18.6 & 0.4 & No & Yes & Electricity, Energy, and Power \\
\hline 17. & South Luzon Tollway & 18.3 & 0.4 & No & No & Transport \\
\hline 18. & Globe Telecom & 17.0 & 0.3 & No & Yes & Telecommunications \\
\hline 19. & East West Bank & 16.8 & 0.3 & No & Yes & Banking \\
\hline 20. & Maynilad Water Service & 16.2 & 0.3 & No & No & Water \\
\hline 21. & MCE Leisure (Philippines) & 15.0 & 0.3 & No & No & Casinos and Gaming \\
\hline 22. & Philippines Long Distance Telephone Company & 15.0 & 0.3 & No & Yes & Telecommunications \\
\hline 23. & SMC Global Power & 15.0 & 0.3 & No & No & Electricity, Energy, and Power \\
\hline 24. & Union Bank of the Philippines & 14.0 & 0.3 & No & Yes & Banking \\
\hline 25. & First Metro Investment Corporation & 12.0 & 0.2 & No & No & Banking \\
\hline 26. & Robinsons Land & 12.0 & 0.2 & No & Yes & Property \\
\hline 27. & Manila North Tollways & 11.9 & 0.2 & No & No & Transport \\
\hline 28. & MTD Manila Expressway & 11.5 & 0.2 & No & No & Transport \\
\hline 29. & Vista Land and Lifescapes & 10.2 & 0.2 & No & Yes & Property \\
\hline 30. & Aboitiz Power & 10.0 & 0.2 & No & Yes & Electricity, Energy, and Power \\
\hline \multicolumn{2}{|c|}{ Total Top 30 LCY Corporate Issuers } & 774.9 & 15.6 & & & \\
\hline \multicolumn{2}{|c|}{ Total LCY Corporate Bonds } & 891.2 & 18.0 & & & \\
\hline \multicolumn{2}{|c|}{ Top 30 as \% of Total LCY Corporate Bonds } & $86.9 \%$ & $86.9 \%$ & & & \\
\hline
\end{tabular}

LCY $=$ local currency, PHP = Philippine peso, USD = United States dollar.

Notes:

1. Data as of end-December 2016.

2. State-owned firms are defined as those in which the government has more than a $50 \%$ ownership stake.

Source: AsianBondsOnline calculations based on Bloomberg LP data. 


\section{Singapore}

Singapore's local currency (LCY) bond market reached a size of SGD333 billion (USD230 billion) at the end of December 2016, reflecting a rise of 2.3\% quarter-on-quarter and 3.2\% year-on-year in the fourth quarter (Q4) of 2016. Growth in the LCY bond market was driven by an increase in the stock of Monetary Authority of Singapore bills and government bonds. Corporate bonds declined 2.0\% quarter-on-quarter but rose $0.3 \%$ year-on-year. Depressed oil prices significantly affected energy companies in 2016 , causing some corporate debt defaults and contributing to the stagnant growth seen in the corporate debt sector.

Table 1: Size and Composition of the LCY Bond Market in Singapore

\begin{tabular}{|c|c|c|c|c|c|c|c|c|c|c|}
\hline & \multicolumn{6}{|c|}{ Outstanding Amount (billion) } & \multicolumn{4}{|c|}{ Growth Rate (\%) } \\
\hline & \multicolumn{2}{|c|}{ Q4 2015} & \multicolumn{2}{|c|}{ Q3 2016} & \multicolumn{2}{|c|}{ Q4 2016} & \multicolumn{2}{|c|}{ Q4 2015} & \multicolumn{2}{|c|}{ Q4 2016} \\
\hline & SGD & USD & SGD & USD & SGD & USD & $q-o-q$ & $y-0-y$ & $q-o-q$ & $y-0-y$ \\
\hline Total & 323 & 228 & 326 & 239 & 333 & 230 & $(0.5)$ & 0.0 & 2.3 & 3.2 \\
\hline Government & 183 & 129 & 183 & 134 & 193 & 133 & $(2.3)$ & (5.7) & 5.6 & 5.4 \\
\hline SGS Bills and Bonds & 106 & 75 & 107 & 78 & 110 & 76 & 2.7 & 7.7 & 2.8 & 4.1 \\
\hline MAS Bills & 78 & 55 & 76 & 56 & 83 & 57 & $(8.5)$ & $(19.4)$ & 9.6 & 7.2 \\
\hline Corporate & 140 & 99 & 143 & 105 & 140 & 97 & 2.1 & 8.5 & $(2.0)$ & 0.3 \\
\hline
\end{tabular}

()$=$ negative, $L C Y=$ local currency, MAS = Monetary Authority of Singapore, $q-0-q=$ quarter-on-quarter, $Q 3=$ third quarter, $Q 4=$ fourth quarter, $S G D=$ Singapore dollar,

SGS = Singapore Government Securities, USD = United States dollar, $y-0-y=$ year-on-year.

Notes:

1. Government bonds are calculated using data from national sources. Corporate bonds are based on AsianBondsOnline estimates.

2. SGS bills and bonds do not include the special issue of Singapore Government Securities held by the Singapore Central Provident Fund.

3. Bloomberg LP end-of-period LCY-USD rates are used.

4. Growth rates are calculated from an LCY base and do not include currency effects.

Sources: Bloomberg LP, Monetary Authority of Singapore, and Singapore Government Securities.

New corporate bond issuance in Singapore amounted to SGD1.5 billion in Q4 2016, declining from SGD4.1 billion in the previous quarter. The state-owned Housing and Development Board had the largest corporate issuance in Q4 2016.

Table 2: Notable Local Currency Corporate Bond Issuance in the Fourth Quarter of 2016

\begin{tabular}{lcc}
\multicolumn{1}{c}{ Corporate Issuers } & $\begin{array}{c}\text { Coupon Rate } \\
(\%)\end{array}$ & $\begin{array}{c}\text { Issued Amount } \\
\text { (SGD million) }\end{array}$ \\
$\begin{array}{l}\text { Housing and Development Board } \\
\text { 5-year bond }\end{array}$ & 2.22 & 900 \\
\hline $\begin{array}{l}\text { Singapore Airlines } \\
\text { 10-year bond }\end{array}$ & 3.13 & 430 \\
\hline $\begin{array}{l}\text { Mapletree Commercial Trust } \\
\text { 7-year bond }\end{array}$ & 2.80 & 85 \\
\hline Starhill Global REIT & & 70 \\
10-year bond & 3.14 & \\
\hline
\end{tabular}

REIT = real estate investment trust, SGD = Singapore dollar.

Source: Bloomberg LP. 
LCY bonds outstanding from the top 30 corporate issuers in Singapore amounted to SGD69.1 billion at the end of December, representing $49.2 \%$ of the total corporate bond stock.

Table 3: Top 30 Issuers of Local Currency Corporate Bonds in Singapore

\begin{tabular}{|c|c|c|c|c|c|c|}
\hline & & Outstanc & Amount & & & \\
\hline & Issuers & $\begin{array}{l}\text { LCY Bonds } \\
\text { (SGD billion) }\end{array}$ & $\begin{array}{l}\text { LCY Bonds } \\
\text { (USD billion) }\end{array}$ & State-Owned & Company & Type of Industry \\
\hline 1. & Housing \& Development Board & 22.5 & 15.6 & Yes & No & Real Estate \\
\hline 2. & United Overseas Bank & 4.7 & 3.2 & No & Yes & Banking \\
\hline 3. & Temasek Financial I & 3.6 & 2.5 & Yes & No & Finance \\
\hline 4. & Land Transport Authority & 3.5 & 2.4 & Yes & No & Transportation \\
\hline 5. & Capitaland & 2.8 & 1.9 & No & Yes & Real Estate \\
\hline 6. & FCL Treasury & 2.4 & 1.6 & No & No & Finance \\
\hline 7. & DBS Bank & 2.2 & 1.5 & No & Yes & Banking \\
\hline 8. & SP Powerassets & 1.9 & 1.3 & No & No & Utilities \\
\hline 9. & Olam International & 1.7 & 1.2 & No & Yes & Consumer Goods \\
\hline 10. & Keppel Corporation & 1.7 & 1.2 & No & Yes & Diversified \\
\hline 11. & DBS Group Holdings & 1.5 & 1.1 & No & Yes & Banking \\
\hline 12. & Oversea-Chinese Banking Corporation & 1.5 & 1.0 & No & Yes & Banking \\
\hline 13. & City Developments Limited & 1.5 & 1.0 & No & Yes & Real Estate \\
\hline 14. & Hyflux & 1.5 & 1.0 & No & Yes & Utilities \\
\hline 15. & Singapore Airlines & 1.4 & 1.0 & No & Yes & Transportation \\
\hline 16. & Public Utilities Board & 1.4 & 1.0 & Yes & No & Utilities \\
\hline 17. & Neptune Orient Lines & 1.3 & 0.9 & No & Yes & Transportation \\
\hline 18. & Capitaland Treasury & 1.2 & 0.8 & No & No & Finance \\
\hline 19. & Mapletree Treasury Services & 1.1 & 0.8 & No & No & Finance \\
\hline 20. & CMT MTN & 1.1 & 0.7 & No & No & Finance \\
\hline 21. & Capitamalls Asia Treasury & 1.0 & 0.7 & No & No & Finance \\
\hline 22. & National University of Singapore & 1.0 & 0.7 & No & No & Education \\
\hline 23. & Ascendas REIT & 1.0 & 0.7 & No & Yes & Finance \\
\hline 24. & Sembcorp Financial Services & 1.0 & 0.7 & No & No & Engineering \\
\hline 25. & Singtel Group Treasury & 0.9 & 0.6 & No & No & Finance \\
\hline 26. & GLL IHT & 0.8 & 0.6 & No & No & Real Estate \\
\hline 27. & Overseas Union Enterprise & 0.8 & 0.6 & No & Yes & Real Estate \\
\hline 28. & Sembcorp Industries & 0.8 & 0.6 & No & Yes & Shipbuilding \\
\hline 29. & Global Logistic Properties & 0.8 & 0.5 & No & Yes & Real Estate \\
\hline 30. & SMRT Capital & 0.8 & 0.5 & No & No & Transportation \\
\hline Tot & I Top 30 LCY Corporate Issuers & 69.1 & 47.7 & & & \\
\hline Tot & I LCY Corporate Bonds & 140.4 & 97.0 & & & \\
\hline Top & 30 as $\%$ of Total LCY Corporate Bonds & $49.2 \%$ & $49.2 \%$ & & & \\
\hline
\end{tabular}

LCY = local currency, SGD = Singapore dollar, USD = United States dollar.

Notes:

1. Data as of end-December 2016.

2. State-owned firms are defined as those in which the government has more than a $50 \%$ ownership stake.

Source: AsianBondsOnline calculations based on Bloomberg LP data. 


\section{Thailand}

Thailand's local currency (LCY) bond market had a total value of THB10,856 billion (USD303 billion) at the end of December 2016, reflecting an expansion of $2.5 \%$ quarter-on-quarter and $8.4 \%$ year-on-year. The rise mainly came from relatively strong growth in corporate bonds and central bank bonds.

Table 1: Size and Composition of the Local Currency Bond Market in Thailand

\begin{tabular}{|c|c|c|c|c|c|c|c|c|c|c|}
\hline & \multicolumn{6}{|c|}{ Outstanding Amount (billion) } & \multicolumn{4}{|c|}{ Growth Rate (\%) } \\
\hline & \multicolumn{2}{|c|}{ Q4 2015} & \multicolumn{2}{|c|}{ Q3 2016} & \multicolumn{2}{|c|}{ Q4 2016} & \multicolumn{2}{|c|}{ Q4 2015} & \multicolumn{2}{|c|}{ Q4 2016} \\
\hline & THB & USD & THB & USD & THB & USD & $q-o-q$ & $y-0-y$ & $q-o-q$ & $y-0-y$ \\
\hline Total & 10,012 & 278 & 10,593 & 306 & 10,856 & 303 & 2.5 & 8.1 & 2.5 & 8.4 \\
\hline Government & 7,494 & 208 & 7,819 & 226 & 7,938 & 222 & 2.5 & 7.8 & 1.5 & 5.9 \\
\hline Government Bonds and Treasury Bills & 3,888 & 108 & 4,035 & 117 & 4,036 & 113 & 5.1 & 13.9 & 0.03 & 3.8 \\
\hline Central Bank Bonds & 2,823 & 78 & 2,961 & 86 & 3,136 & 88 & (1.4) & 2.9 & 5.9 & 11.1 \\
\hline State-Owned Enterprise and Other Bonds & 782 & 22 & 822 & 24 & 765 & 21 & 4.1 & $(1.4)$ & $(6.9)$ & $(2.2)$ \\
\hline Corporate & 2,517 & 70 & 2,775 & 80 & 2,919 & 81 & 2.5 & 9.0 & 5.2 & 16.0 \\
\hline
\end{tabular}

()$=$ negative, $L C Y=$ local currency, q-o-q = quarter-on-quarter, Q3 = third quarter, Q4 = fourth quarter, THB = Thai baht, USD = United States dollar, $y$-o-y = year-on-year. Notes:

1. Calculated using data from national sources.

2. Bloomberg end-of-period LCY-USD rates are used.

3. Growth rates are calculated from an LCY base and do not include currency effects.

Sources: Bank of Thailand and Bloomberg LP.

Newly issued LCY corporate bonds amounted to THB502.5 billion in Q4 2016, an increase from THB469.6 billion in Q3 2016. The five largest LCY corporate bond issues came from various industry groups encompassing food and beverages, cement production, communications, transportation, and banking.

Table 2: Notable Local Currency Corporate Bond Issuance in the Fourth Quarter of 2016

\begin{tabular}{|c|c|c|c|c|c|}
\hline Corporate Issuers & $\begin{array}{c}\text { Coupon Rate } \\
(\%)\end{array}$ & $\begin{array}{l}\text { Issued Amount } \\
\text { (THB billion) }\end{array}$ & Corporate Issuers & $\begin{array}{c}\text { Coupon Rate } \\
(\%)\end{array}$ & $\begin{array}{l}\text { Issued Amount } \\
\text { (THB billion) }\end{array}$ \\
\hline Berli Jucker & & & Bangkok Mass Transit System & & \\
\hline 3.5-year bond & 2.71 & 17,920 & 3-year bond & 2.46 & 5,500 \\
\hline 5-year bond & 3.06 & 3,050 & 5-year bond & 2.85 & 2,200 \\
\hline 7-year bond & 3.77 & 2,100 & 7-year bond & 3.30 & 4,100 \\
\hline 9-year bond & 4.09 & 1,200 & 10 -year bond & 3.87 & 10,200 \\
\hline 10-year bond & 4.27 & 3,720 & Bank of Ayudhya & & \\
\hline Siam Cement & & & 2-year bond & 1.94 & 9,000 \\
\hline 4-year bond & 3.00 & 25,000 & 3-year bond & 2.09 & 6,000 \\
\hline \multicolumn{6}{|c|}{ True Move H Universal Communication } \\
\hline 5-year bond & 4.50 & 10,975 & & & \\
\hline 7-year bond & 5.00 & 4,545 & & & \\
\hline 10-year bond & 5.50 & 7,480 & & & \\
\hline
\end{tabular}

THB = Thai baht.

Source: Bloomberg LP. 
The LCY bonds outstanding of Thailand's top 30 corporate issuers had a combined total of THB1,628.9 billion at the end of December 2016, constituting $55.8 \%$ of the total LCY corporate bond stock. CP All was the top corporate issuer in 2016.

Table 3: Top 30 Issuers of LCY Corporate Bonds in Thailand

\begin{tabular}{|c|c|c|c|c|c|c|}
\hline & & Outstan & Amount & & & \\
\hline & Issuers & $\begin{array}{l}\text { LCY Bonds } \\
\text { (THB billion) }\end{array}$ & $\begin{array}{l}\text { LCY Bonds } \\
\text { (USD billion) }\end{array}$ & State-Owned & Listed Company & Type of Industry \\
\hline 1. & CP All & 198.0 & 5.5 & No & Yes & Commerce \\
\hline 2. & Siam Cement & 166.5 & 4.6 & Yes & Yes & Construction Materials \\
\hline 3. & PTT & 137.4 & 3.8 & Yes & Yes & Energy and Utilities \\
\hline 4. & Bank of Ayudhya & 92.3 & 2.6 & No & Yes & Banking \\
\hline 5. & Charoen Pokphand Foods & 85.0 & 2.4 & No & Yes & Food and Beverage \\
\hline 6. & Berli Jucker & 82.0 & 2.3 & No & Yes & Food and Beverage \\
\hline 7. & Thai Airways International & 59.3 & 1.7 & Yes & Yes & Transportation and Logistics \\
\hline 8. & Kasikorn Bank & 50.0 & 1.4 & No & Yes & Banking \\
\hline 9. & Tisco Bank & 49.5 & 1.4 & No & No & Banking \\
\hline 10. & Indorama Ventures & 47.4 & 1.3 & No & Yes & Petrochemicals and Chemicals \\
\hline 11. & Krungthai Card & 46.5 & 1.3 & Yes & Yes & Banking \\
\hline 12. & True Move H Universal Communication & 43.0 & 1.2 & No & No & Communications \\
\hline 13. & Banpu & 41.3 & 1.2 & No & Yes & Energy and Utilities \\
\hline 14. & Toyota Leasing Thailand & 40.9 & 1.1 & No & No & Finance and Securities \\
\hline 15. & The Siam Commercial Bank & 40.0 & 1.1 & No & Yes & Banking \\
\hline 16. & Mitr Phol Sugar & 37.9 & 1.1 & No & No & Food and Beverage \\
\hline 17. & Land \& Houses & 36.3 & 1.0 & No & Yes & Property and Construction \\
\hline 18. & CPF Thailand & 32.6 & 0.9 & No & Yes & Food and Beverage \\
\hline 19. & Thanachart Bank & 32.5 & 0.9 & No & No & Banking \\
\hline 20. & PTT Exploration and Production Company & 32.1 & 0.9 & Yes & Yes & Energy and Utilities \\
\hline 21. & TPI Polene & 32.0 & 0.9 & No & Yes & Property and Construction \\
\hline 22. & Advanced Wireless & 31.6 & 0.9 & No & Yes & Communications \\
\hline 23. & True Corp & 31.2 & 0.9 & No & Yes & Communications \\
\hline 24. & $\mathrm{CH}$. Karnchang & 29.0 & 0.8 & No & Yes & Property and Construction \\
\hline 25. & Thai Oil & 28.0 & 0.8 & Yes & Yes & Energy and Utilities \\
\hline 26. & Thai Union Group & 26.3 & 0.7 & No & Yes & Food and Beverage \\
\hline 27. & Minor International & 25.8 & 0.7 & No & Yes & Food and Beverage \\
\hline 28. & TMB Bank & 25.4 & 0.7 & No & Yes & Banking \\
\hline 29. & Glow Energy & 24.6 & 0.7 & No & Yes & Energy and Utilities \\
\hline 30. & Quality Houses & 24.5 & 0.7 & No & Yes & Property and Construction \\
\hline Tot & Top 30 LCY Corporate Issuers & $1,628.9$ & 45.5 & & & \\
\hline Tot & LCY Corporate Bonds & $2,918.9$ & 81.5 & & & \\
\hline Top & 30 as $\%$ of Total LCY Corporate Bonds & $55.8 \%$ & $55.8 \%$ & & & \\
\hline
\end{tabular}

LCY = local currency, THB = Thai baht, USD = United States dollar.

Notes:

1. Data as of end-December 2016

2. State-owned firms are defined as those in which the government has more than a $50 \%$ ownership stake.

Source: AsianBondsOnline calculations based on Bloomberg LP data. 


\section{Viet Nam}

Viet Nam's local currency (LCY) bond market was valued at VND996 trillion (USD44 billion) at the end of December. On a quarter-on-quarter basis, growth contracted $4.4 \%$ in the fourth quarter of 2016, due largely to a decline in central bank bonds outstanding as redemptions exceeded new issuance.

Table 1: Size and Composition of the Local Currency Bond Market in Viet Nam

\begin{tabular}{|c|c|c|c|c|c|c|c|c|c|c|}
\hline & \multicolumn{6}{|c|}{ Outstanding Amount (billion) } & \multicolumn{4}{|c|}{ Growth Rate (\%) } \\
\hline & \multicolumn{2}{|c|}{ Q4 2015} & \multicolumn{2}{|c|}{ Q3 2016} & \multicolumn{2}{|c|}{ Q4 2016} & \multicolumn{2}{|c|}{ Q4 2015} & \multicolumn{2}{|c|}{ Q4 2016} \\
\hline & VND & USD & VND & USD & VND & USD & $q-o-q$ & $y-0-y$ & $q-o-q$ & $y-0-y$ \\
\hline Total & 937,601 & 42 & $1,041,024$ & 47 & 995,720 & 44 & 10.3 & 5.2 & $(4.4)$ & 6.2 \\
\hline Government & 904,310 & 40 & 999,630 & 45 & 949,725 & 42 & 9.8 & 3.2 & $(5.0)$ & 5.0 \\
\hline Treasury Bonds & 599,300 & 27 & 719,847 & 32 & 736,932 & 32 & 11.8 & 14.1 & 2.4 & 23.0 \\
\hline Central Bank Bonds & 98,191 & 4 & 69,999 & 3 & 8,000 & 0.4 & 8.8 & $(26.9)$ & $(88.6)$ & (91.9) \\
\hline $\begin{array}{l}\text { State-Owned } \\
\text { Enterprise Bonds }\end{array}$ & 206,818 & 9 & 209,784 & 9 & 204,792 & 9 & 4.9 & $(4.4)$ & $(2.4)$ & $(1.0)$ \\
\hline Corporate & 33,292 & 1 & 41,394 & 2 & 45,996 & 2 & 24.4 & 114.3 & 11.1 & 38.2 \\
\hline
\end{tabular}

()$=$ negative, $L C Y=$ local currency, $q-0-q=$ quarter-on-quarter, $Q 3=$ third quarter, $Q 4=$ fourth quarter, USD = United States dollar, VND = Vietnamese dong, $y$-o- $y=$ year-on-year. Notes:

1. Bloomberg LP end-of-period LCY-USD rates are used.

2. Growth rates are calculated from an LCY base and do not include currency effects.

Sources: Bloomberg LP and Vietnam Bond Market Association.

In the fourth quarter of 2016, new corporate bond issues reached VND4.6 trillion, higher on both a quarter-on-quarter and year-on-year basis. Leading the list of new corporate debt issuers was Vietcombank, which issued 10-year bonds worth VND2.0 trillion in November.

Table 2: Notable Local Currency Corporate Bond Issuance in the Fourth Quarter of 2016

\begin{tabular}{lcc}
\multicolumn{1}{c}{ Corporate Issuer } & $\begin{array}{c}\text { Coupon Rate } \\
(\%)\end{array}$ & $\begin{array}{c}\text { Issued Amount } \\
\text { (VND billion) }\end{array}$ \\
$\begin{array}{l}\text { Vietcombank } \\
\text { 10-year bond }\end{array}$ & floating & 2,000 \\
\hline Vietnam Electrical Equipment & & \\
3-year bond & floating & 1,800 \\
\hline Sai Gon Thuong Tin Real Estate & & \\
2-year bond & 12.00 & 200 \\
4-year bond & 10.50 & 400 \\
\hline
\end{tabular}

VND = Viertnamese dong.

Sources: Bloomberg LP and Vietnam Bond Market Association. 
Viet Nam's corporate bond market comprised a total of 27 corporate firms, with outstanding bonds valued at VND46.0 trillion at the end of December. The largest corporate issuer was Masan Consumer Holdings with outstanding bonds of VND11.1 trillion, representing $24.1 \%$ of the aggregate stock of corporate bonds.

Table 3: Corporate Issuers of Local Currency Corporate Bonds in Viet Nam

\begin{tabular}{|c|c|c|c|c|c|c|}
\hline & & Outstand & Amount & & & \\
\hline & Issuers & $\begin{array}{l}\text { LCY Bonds } \\
\text { (VND billion) }\end{array}$ & $\begin{array}{l}\text { LCY Bonds } \\
\text { (USD billion) }\end{array}$ & State-Owned & Company & Type of Industry \\
\hline 1. & Masan Consumer Holdings & 11,100 & 0.49 & No & No & Diversified Operations \\
\hline 2. & Vingroup JSC & 8,000 & 0.35 & No & Yes & Real Estate \\
\hline 3. & Asia Commercial Joint Stock & 4,600 & 0.20 & No & No & Finance \\
\hline 4. & Hoang Anh Gia Lai & 4,000 & 0.18 & No & Yes & Real Estate \\
\hline 5. & Techcom Bank & 3,000 & 0.13 & No & No & Banking \\
\hline 6. & Ho Chi Minh City Infrastructure & 2,102 & 0.09 & No & Yes & Infrastructure \\
\hline 7. & Vietcombank & 2,000 & 0.09 & Yes & Yes & Banking \\
\hline 8. & Vietnam Electrical Equipment & 1,800 & 0.08 & No & Yes & Manufacturing \\
\hline 9. & Agro Nutrition International & 1,300 & 0.06 & No & No & Agriculture \\
\hline 10. & DIC Corporation & 1,000 & 0.04 & Yes & No & Chemicals \\
\hline 11. & Ocean Group & 980 & 0.04 & No & Yes & Consulting Services \\
\hline 12. & Saigon-Hanoi Securities Corporation & 950 & 0.04 & No & Yes & Finance \\
\hline 13. & Sai Gon Thuong Tin Real Estate & 600 & 0.03 & No & Yes & Real Estate \\
\hline 14. & Khang Dien House Trading and Investment & 534 & 0.02 & No & Yes & Building and Construction \\
\hline 15. & Hoangquan & 500 & 0.02 & No & Yes & Real Estate \\
\hline 16. & Saigon Securities & 500 & 0.02 & No & Yes & Finance \\
\hline 17. & Tasco Corporation & 500 & 0.02 & No & Yes & Engineering and Construction \\
\hline 18. & Vietinbank Securities & 500 & 0.02 & Yes & Yes & Finance \\
\hline 19. & An Phat Plastic \& Green Environment & 450 & 0.02 & No & Yes & Industrial \\
\hline 20. & Sotrans Corporation & 400 & 0.02 & No & No & Logistics \\
\hline 21. & Vietnam Investment Construction and Trading & 350 & 0.02 & No & Yes & Building and Construction \\
\hline 22. & Hung Vuong Corp. & 300 & 0.01 & No & Yes & Food \\
\hline 23. & Ha Do Corporation & 200 & 0.01 & No & Yes & Construction \\
\hline 24. & Son Ha International & 110 & 0.005 & No & Yes & Building and Construction \\
\hline 25. & Dongnai Plastic & 100 & 0.004 & No & Yes & Industrial \\
\hline 26. & Fecon & 70 & 0.003 & No & Yes & Engineering and Construction \\
\hline 27. & Construction Joint Stock Company No. 3 & 50 & 0.002 & No & Yes & Real Estate \\
\hline Tota & I LCY Corporate Issuers & 45,996 & 2.02 & & & \\
\hline
\end{tabular}

$\mathrm{LCY}=$ local currency, USD = United States dollar, VND = Vietnamese dollar.

Notes:

1. Data as of end-December 2016.

2. State-owned firms are defined as those in which the government has more than a $50 \%$ ownership stake.

Sources: AsianBondsOnline calculations based on Bloomberg LP and Vietnam Bond Market Association data. 


\section{Asia Bond Monitor}

March 2017

This publication reviews recent developments in East Asian local currency bond markets along with the outlook, risks, and policy options. It covers the 10 members of the Association of Southeast Asian Nations and the People's Republic of China; Hong Kong, China; and the Republic of Korea.

\section{About the Asian Development Bank}

ADB's vision is an Asia and Pacific region free of poverty. Its mission is to help its developing member countries reduce poverty and improve the quality of life of their people. Despite the region's many successes, it remains home to a large share of the world's poor. ADB is committed to reducing poverty through inclusive economic growth, environmentally sustainable growth, and regional integration.

Based in Manila, ADB is owned by 67 members, including 48 from the region. Its main instruments for helping its developing member countries are policy dialogue, loans, equity investments, guarantees, grants, and technical assistance. 